\title{
Anomia-associated bryozoans from the upper Pliocene (Piacenzian) lower Tamiami Formation of Florida, USA
}

\author{
Emanuela Di Martino, Paul D. Taylor, and Roger W. Portell
}

\begin{abstract}
Commercial mining northeast of Sarasota, SW Florida (USA), since the 1960s has exposed Plio-Pleistocene marine shell beds of the Tamiami Formation, a complex sequence of mixed carbonate and siliciclastic beds containing a malacofauna that is a mixture of subtropical and temperate species. Material used for the current study consists of shells of the bivalve Anomia simplex d'Orbigny, 1853 encrusted by bryozoans. The shells were collected from Units 10/11 of the lower Tamiami Formation, estimated as being late Pliocene (Piacenzian). This paper describes the bryozoan fauna associated with these 'jingle shells', which is of relatively low diversity, totaling 29 species, and comprises one cyclostome and 28 cheilostomes. Six cheilostome species are new: Micropora stellata sp. nov., Microporella sarasotaensis sp. nov., Microporella tamiamiensis sp. nov., Pourtalesella chiarae sp. nov., Spiniflabellum laurae sp. nov., and Trypostega composita sp. nov. Of the previously described species, six are extant and have western Atlantic distributions, while 12 species are known only from the fossil record. The bulk of the assemblage comprises a limited number of species represented by hundreds of colonies, while the remaining species are rare and represented by a single or a few colonies. Colonization of the shells is likely to have happened postmortem, considering the high percentage of valves encrusted on both surfaces. A large number of overgrowth interactions have been observed among the bryozoan colonies, thus this taxonomic revision is the necessary baseline for ecological analyses aiming to establish a ranking of species in a competitive hierarchy.
\end{abstract}

Emanuela Di Martino. Department of Earth Sciences, Natural History Museum, Cromwell Road, SW7 5BD, London, United Kingdom. e.di-martino@nhm.ac.uk

Paul D. Taylor. Department of Earth Sciences, Natural History Museum, Cromwell Road, SW7 5BD, London, United Kingdom. p.taylor@nhm.ac.uk

Roger W. Portell. Division of Invertebrate Paleontology, Florida Museum of Natural History, University of Florida, Gainesville, FL 32611-7800, USA. portell@flmnh.ufl.edu

http://zoobank.org/236D37F3-8616-4CF3-ADE7-54F84499D6EF

Di Martino, Emanuela, Taylor, Paul D., and Portell, Roger W. 2019. Anomia-associated bryozoans from the upper Pliocene (Piacenzian) lower Tamiami Formation of Florida, USA. Palaeontologia Electronica 22.1.11A 1-65. https://doi.org/10.26879/920 palaeo-electronica.org/content/2019/2404-tamiami-formation-bryozoans

Copyright: March 2019 Palaeontological Association.

This is an open access article distributed under the terms of Attribution-NonCommercial-ShareAlike 4.0 International (CC BY-NC-SA 4.0), which permits users to copy and redistribute the material in any medium or format, provided it is not used for commercial purposes and the original author and source are credited, with indications if any changes are made.

creativecommons.org/licenses/by-nc-sa/4.0/ 
Keywords: Bryozoa; Cyclostomata; Cheilostomata; new species; Piacenzian; Tamiami Formation

\section{INTRODUCTION}

The monograph published by Canu and Bassler in 1923 is still the most comprehensive work yet published on North American Neogene and Quaternary bryozoans. It includes bryozoan faunas from Miocene to Pleistocene formations in several North American states (California, Florida, Maryland, North Carolina, South Carolina, Virginia) as well as the Caribbean (Costa Rica, Cuba, Dominican Republic, Jamaica), totaling approximately 250 species.

Among formations exposed in Florida, Canu and Bassler (1923) reported bryozoans from the lower Miocene Chipola Formation (only five species, cf. 47 in the subsequent, more comprehensive work of Scolaro (1968), and 60 in the most recent revision of Di Martino et al. (2017)), the upper Miocene Choctawhatchee Formation (now assigned to the upper Pliocene Jackson Bluff Formation; 22 species), and the lower Pleistocene Caloosahatchee Formation (23 species).

No information was available on the bryozoan fauna from the Plio-Pleistocene Tamiami Formation until the unpublished MSc dissertation of Echols (1960) that aimed to describe this previously unknown bryozoan fauna and to analyze its ecological and stratigraphical significance. Echols (1960) reported 26 species, including 25 cheilostomes and one cyclostome, from units exposed on the west side of State Road 29 at Sunniland in Collier County, corresponding to the lower Tamiami Formation of Zullo and Harris (1992). Unfortunately, Echols (1960) provided no images of the species described, precluding any significant comparisons with the assemblage studied here.

After Echols' work, Knowles (2008) reported bryozoans from the Tamiami Formation (upper units) in a paper revising three species of the genus Floridina from Neogene Coastal Plain deposits of North America. In addition, Darrell and Taylor (1989) reported bryozoans associated with coral symbionts of hermit crabs from the so-called 'Pinecrest Beds', which represent the upper Tamiami Formation in modern terminology.

This present paper aims to describe the taxonomy of the bryozoans associated with newly collected Anomia-shells from the late Pliocene lower Tamiami Formation (units 10/11). We add new bryozoan records for this formation, introduce six new species, and provide improved descriptions, illustrations, and taxonomy for existing species. The taxonomic baseline necessary for an ecological study in preparation of competition for substrate space is thus established.

\section{MATERIALS AND METHODS}

Material used for this study was collected in July 2017 by two of us (EDM and RWP) from Phase 10 excavations (now water-filled) of the SMR Aggregates quarries, situated northeast of Sarasota, Florida $\left(27.373907^{\circ}, \quad-82.376859^{\circ}\right.$; WGS84) (Figure 1). Excavations exposed the marine shell-rich Plio-Pleistocene beds of the Tamiami Formation (Figure 2), a complex sequence containing mixed carbonate and siliciclastic beds. Based on Zullo and Harris (1992), the Tamiami Formation is divided into upper and lower parts. The upper Tamiami Formation is subdivided into upper Pinecrest beds and lower Pinecrest beds with predominantly tropical to temperate marine mollusks and corals in unconsolidated sediments deposited at water depths of less than $30 \mathrm{~m}$ (Allmon et al., 1993). The lower Tamiami Formation is characterized by a mixture of subtropical and temperate species, but the fauna appears to be leached of most of its aragonitic shells.

We picked 867 shells (left valves) of the bivalve Anomia simplex d'Orbigny, 1853, commonly known as 'jingle shells' (Figure 3 ), visibly encrusted by bryozoans, from Units 10/11 of the

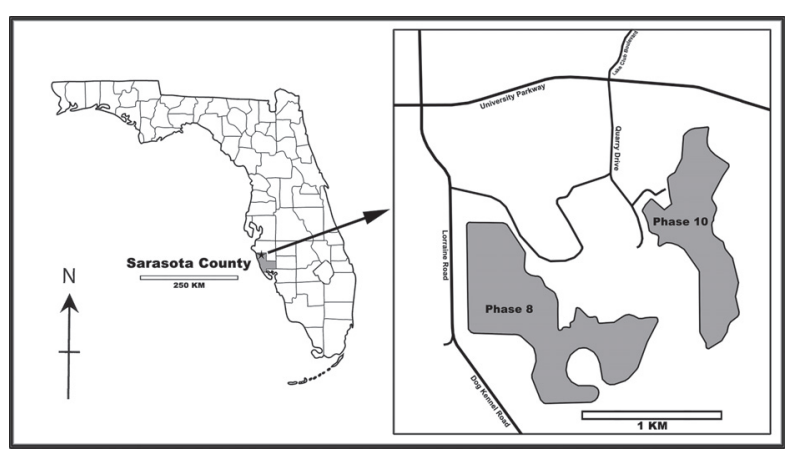

FIGURE 1. Location of the collecting locality (Phase 10 excavations of the SMR Aggregates quarries), northeast of Sarasota, Florida. 


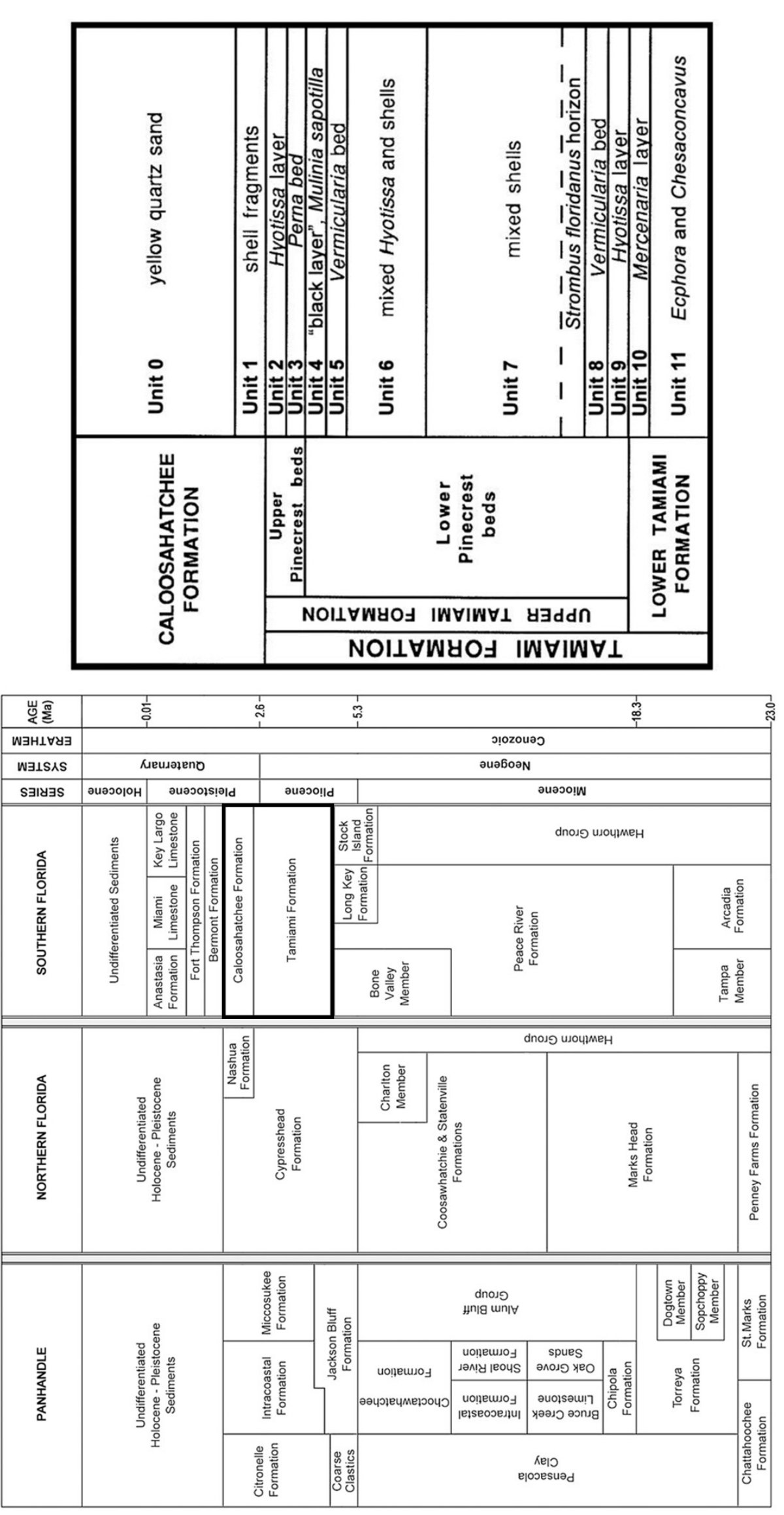

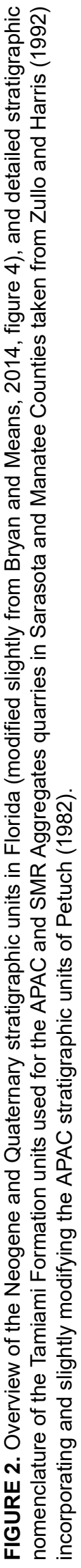




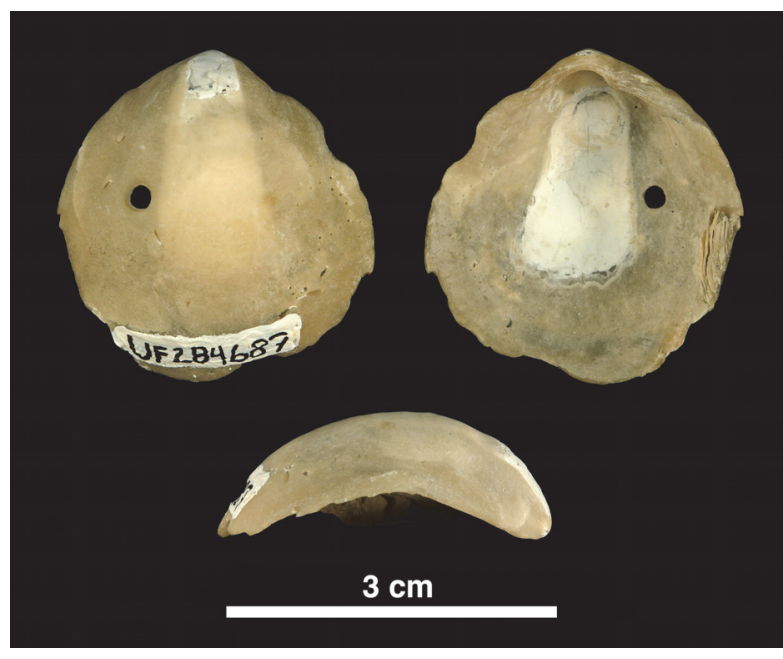

FIGURE 3. Anomia simplex d'Orbigny, 1853

lower Tamiami Formation (Petuch, 1982; Zullo and Harris, 1992), estimated as being $3.0( \pm 0.5) \mathrm{Ma}$ and corresponding to a late Pliocene (Piacenzian) age, based on ${ }^{87} \mathrm{Sr} / 86 \mathrm{Sr}$ isotope dating of bivalves, paleomagnetism, and invertebrate and vertebrate biochronology (Jones et al., 1991). Before examining the encrusting bryozoan colonies, the shell substrates were gently cleaned under running water, scrubbed with a soft toothbrush, washed in an ultrasonic bath to remove sediment, and airdried. Scanning electron microscopy (SEM) was conducted on the best-preserved specimens. SEM observations were made on uncoated specimens using a low-vacuum scanning electron microscope (LEO VP-1455) at the Natural History Museum in London (NHMUK). Zooidal measurements were taken from SEM images using the image processing program ImageJ (available at https:// imagej.nih.gov/). Each measurement is given in the text as the mean value in $\mu \mathrm{m} \pm$ the standard deviation, observed range, number of specimens used, and total number of measurements (the latter two values enclosed in parentheses). Abbreviations for the measurements are: ApL, aperture length; ApW, aperture width; AvL, avicularium length; AvW, avicularium width; AvOpL, avicularium opesia length; AvOpW, avicularium opesia width; FWL, frontal wall length; FWW, frontal wall width; OL, orifice length; OW, orifice width; OWmin, minimum orifice width; OWmax, maximum orifice width; OvL, ovicell length; OvW, ovicell width; ZcL, zooeciule length; $\mathrm{ZcW}$, zooeciule width; ZL, autozooid length; and ZW, autozooid width.

For taxonomic comparisons, the holotypes of Micropora robusta Cook, 1985 (NHMUK 1972.3.3.1) and Cellepora umbilicata Lonsdale,
1845 (NHMUK D53195) were studied. Through the kindness of JoAnn Sanner (USNM), we were able to obtain new SEM images of the holotypes of Amphiblestrum constrictum Ulrich and Bassler, 1904 (USNM 68459), Amphiblestrum tenuiparietis Canu and Bassler, 1923 (USNM 68460); syntypes of Cyclocolposa perforata Canu and Bassler, 1923 (USNM 68617, two specimens), Cycloperiella rubra Canu and Bassler, 1923 (USNM 68620, two specimens), Smittina maleposita Canu and Bassler, 1923 (USNM 68641), Stephanollina vorax (Canu and Bassler, 1923) (USNM 651310 and USNM 651312); hypotype of Micropora coriacea (Esper, 1791) sensu Canu and Bassler (1923) (USNM 68480); plesiotypes of Metroperiella reversa (Ulrich and Bassler, 1904) (USNM 68651) and Stephanosella biaperta Michelin, 1842 sensu Canu and Bassler (1923) (USNM 68544 and USNM 68546). All figured and type specimens from the Tamiami Formation are registered in the paleontological collections of the Invertebrate Paleontology Division, Florida Museum of Natural History, University of Florida (acronym UF).

\section{SYSTEMATIC PALEONTOLOGY}

Order Cyclostomata Busk, 1852

Suborder Tubuliporina Milne Edwards, 1838

Family Oncousoeciidae Canu, 1918

Genus Oncousoecia Canu, 1918 Oncousoecia sp.

Figure 4

Figured material. UF 305758 (Shell 111). Pliocene, lower Tamiami Formation.

Description. Colony encrusting, low, flat, oligoserial, ribbon-like (Figure 4.1-2). Autozooids distinct, bordered by faint furrows, sinuous, elongate, with isolated, transversely elliptical apertures and short peristomes (Figure 4.3). Frontal wall with thick, transverse, undulose wrinkles and circular pseudopores less than $5 \mu \mathrm{m}$ in diameter (Figure 4.4). Gonozooid transversely elongate, $340 \mu \mathrm{m}$ long by $430 \mu \mathrm{m}$ wide, not penetrated by autozooidal peristomes (Figure 4.3, 5); ooeciostome terminal, short; ooeciopore transversely elliptical, $30 \mu \mathrm{m}$ long by $70 \mu \mathrm{m}$ wide (Figure 4.6). Distal fringe of basal lamina including 2-4 rows of kenozooids (Figure 4.3, 5). Terminal diaphragms present, closing the apertures of some of the oldest autozooids (Figure 4.6). Protooecium and ancestrula not observed.

Measurements $(\mu \mathrm{m})$. FWL 310 $\pm 42,258-378$ (1, 10); FWW 138 $\pm 20,118-176(1,10)$; ApL 112 \pm 11 ,

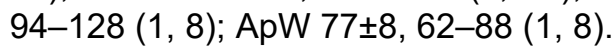



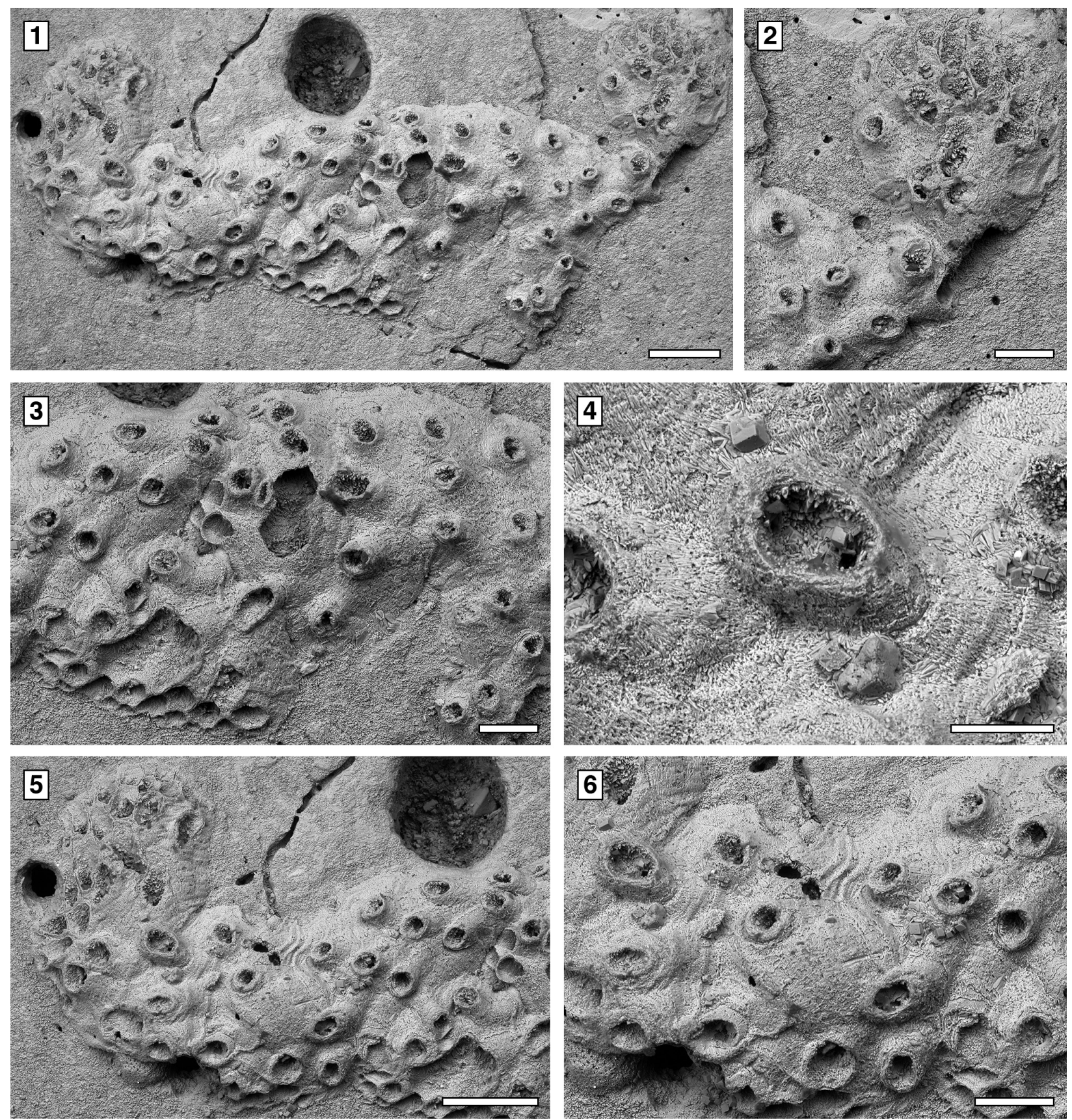

FIGURE 4. Oncousoecia sp., UF 305758 (Shell 111), Pliocene, lower Tamiami Formation Units 10/11. 1, general view of the ribbon-like colony $(400 \mu \mathrm{m}) .2$, close-up of the left lobe $(200 \mu \mathrm{m})$. 3, part of the colony including several autozooids, a broken gonozooid and basal lamina with two rows of kenozooids (200 $\mu \mathrm{m})$. 4, close-up of an autozooid with elliptical aperture and wrinkled, pseudoporous frontal wall $(100 \mu \mathrm{m})$. 5, part of the colony with complete gonozooid and ooeciopore and distal fringe of basal lamina including several rows of kenozooids (400 $\mu \mathrm{m})$. 6, close-up of the gonozooid $(200 \mu \mathrm{m})$.

Remarks. Oncousoecia sp. is the only cyclostome species present in our sample. Species-level identification is difficult on the basis of a single colony, given the paucity and high variability of skeletal characters among cyclostomes.
Order Cheilostomata Busk, 1852

Superfamily Membraniporoidea Busk, 1852

Family Membraniporidae Busk, 1852

Genus Acanthodesia Canu and Bassler, 1919

Acanthodesia cf. denticulata (Busk, 1856)

Figure 5 

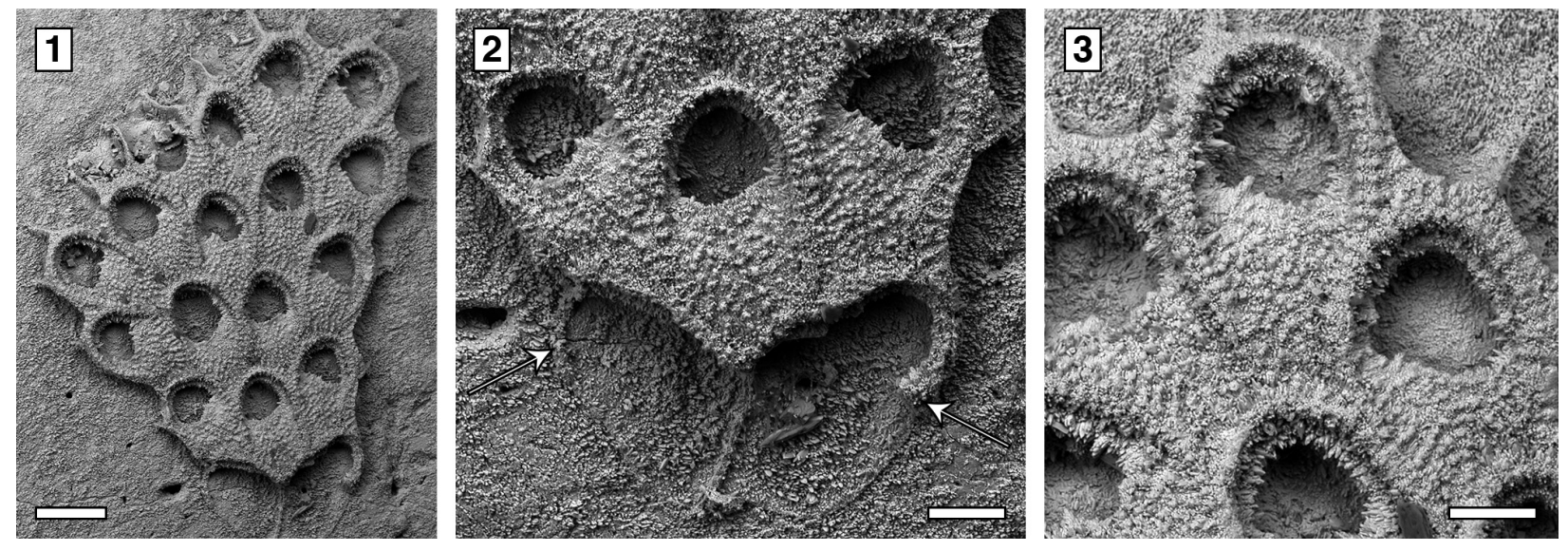

FIGURE 5. Acanthodesia cf. denticulata (Busk, 1856), UF 305759 (Shell 370), Pliocene, lower Tamiami Formation Units 10/11. 1, general view of the small colony available $(200 \mu \mathrm{m}) .2$, close-up of the outline of the twinned ancestrula (see arrows) and first budded zooids $(100 \mu \mathrm{m})$. 3, close-up of autozooids with cryptocystal spine-like projections in the opesia $(100 \mu \mathrm{m})$.

cf. 1856 Membranipora denticulata Busk, p. 176, pl. 7, figures 1, 2.

cf. 1873 Biflustra denticulata Smitt, p. 18, pl. 4, figures 89-91.

cf. 1923 Hemiseptella filimargo Canu and Bassler, p. 71, pl. 10, figure 9.

cf. 1928a Hemiseptella denticulata Canu and Bassler, p.62, pl. 9, figure 9.

cf. 1928a Hemiseptella hexagonalis Canu and Bassler, p. 63 , pl. 28 , figure 9 .

cf. 2005 Biflustra denticulata Winston, p. 6, figures 13.

Figured material. UF 305759 (Shell 370). Pliocene, lower Tamiami Formation.

Description. Colony encrusting, multiserial, unilamellar, comprising only 15 zooids up to the fourth generation (including early astogeny) and the outline of the ancestrular complex (Figure 5.1). Ancestrula twinned, with zooids adjacent to each other for about half of their length, then diverging outwards at an angle of $90^{\circ}, 316-360 \mu \mathrm{m}$ long by 198-210 $\mu \mathrm{m}$ wide (Figure 5.2, see arrows); a single autozooid budded laterally from both ancestrular zooids and placed centrally, two autozooids budded distolaterally, one from each ancestrular zooid. Autozooids distinct, boundaries marked by a fine fissure and also by a beaded mural rim distally, arranged quincuncially, subrectangular to clubshaped with rounded distal margin and concave proximal margin, elongate (mean L/W 1.76). Mural rim salient distally but indistinct elsewhere. Gymnocyst absent. Cryptocyst very narrow distally, extensive proximally occupying about two-thirds of the zooidal surface, flat to slightly convex proximal to the opesia, pustulose. Opesia reduced to one-third of the zooidal frontal surface, roughly transversely D-shaped and equidimensional with a variable number of cryptocystal spine-like projections (Figure 5.3).

Measurements $(\mu \mathrm{m})$. ZL 344 $\pm 28,292-388(1,10)$; ZW 195 $\pm 10,179-213$ (1, 10); OL 124 $\pm 5,114-128$ $(1,7)$; OW 125 $\pm 4,120-132(1,7)$.

Remarks. The Tamiami Formation species is very similar to the recent Acanthodesia denticulata in its general appearance, but differs from this species in having smaller autozooids and in the lack of gymnocystal tubercles on the proximal corners of the zooids. However, both of these differences may be due to the small size of the colony, which is limited to the early astogenetic stages. The illustration of Hemiseptella filimargo Canu and Bassler, 1923 from the Pliocene of Virginia shows what may be the same species. We prefer to use the genus Acanthodesia Canu and Bassler, 1919 rather than Biflustra d'Orbigny, 1852 because of the membraniporiform encrusting colonies, the type species of Biflustra having an erect vincularian colony (see also Taylor and Tan, 2015; Di Martino et al., 2017; Di Martino and Taylor, 2018).

\section{Acanthodesia sp.}

Figure 6

Figured material. UF 305760 (Shell 500). Pliocene, lower Tamiami Formation.

Description. Colony encrusting, multiserial, unilaminar, fan-shaped (Figure 6.1). Autozooids distinct, boundaries marked by a fine fissure and also by a beaded mural rim distally, arranged in alternating, parallel rows, subrectangular to clubshaped with rounded distal margin and straight to 

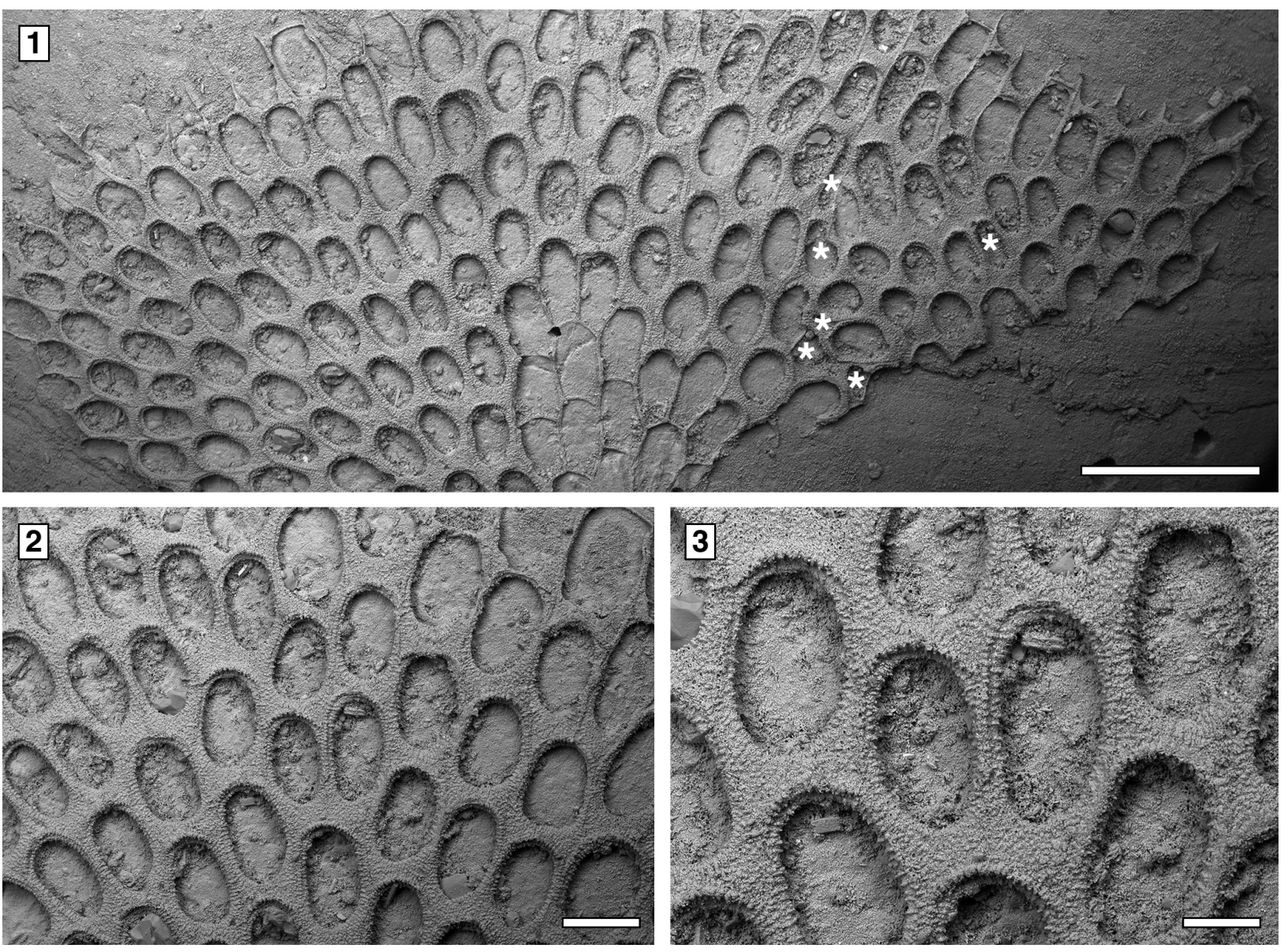

FIGURE 6. Acanthodesia sp., UF 305760 (Shell 500), Pliocene, lower Tamiami Formation Units 10/11. 1, general view of the extensive sheet-like colony $(2 \mathrm{~mm})$, with asterisks indicating kenozooids and/or irregularly shaped autozooids forming at the edges of abutting lobes/colonies. 2, group of autozooids (400 $\mu \mathrm{m})$. 3, close-up of slender autozooids placed at row bifurcation $(200 \mu \mathrm{m})$.

concave proximal margin, elongate (mean L/W 1.46) (Figure 6.2). Autozooids situated immediately before row bifurcations similar in size to autozooids elsewhere; autozooids at row bifurcations slender (mean L/W 1.91) (Figure 6.3). Mural rim salient only distally. Gymnocyst absent. Cryptocyst very narrow distally and laterally, gently sloping down towards the opesia, slightly broader proximally and up to one-quarter of zooidal length, flat to slightly concave, pustulose, with pustules encircling the opesia aligned in radial rows and sometimes minute denticles projecting into it; proximomedial plate absent. Opesia ovoidal to elliptical, occupying nearly all frontal surface (Figure 6.3). Kenozooids and/or irregularly shaped autozooids forming at the edges of abutting colonies (Figure 6.1, see asterisks).

Measurements $(\mu \mathrm{m})$. ZL 532 $\pm 75,445-716(2,20)$;

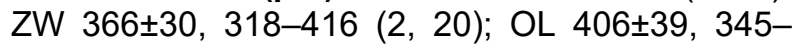

492 (2, 20); OW 266 $\pm 36,204-330$ (2, 20); $Z L^{*}$ 621 $\pm 106,444-804(2,10) ; Z W^{*} 325 \pm 48,250-379$ $(1,10)$. *Zooids located at row bifurcations.

Remarks. The paucity of morphological characters makes the taxonomy of this genus particularly difficult. In previous works, fossil species from North America were frequently attributed to different varieties of Acanthodesia savartii (Audouin, 1826), whose type material is missing. The Tamiami Formation species is distinguished from known Cenozoic North American congeners in having larger zooids and also autozooids located immediately before row bifurcations similar in size to autozooids from elsewhere in the colony. Indeed, most species of Acanthodesia have exceptionally larger zooids preceding row bifurcations. However, Acanthodesia oblongula (Ulrich and Bassler, 1904) also lacks large zooids at row bifurcations (see Canu and Bassler, 1923, pl. 10, figures 1-3). 

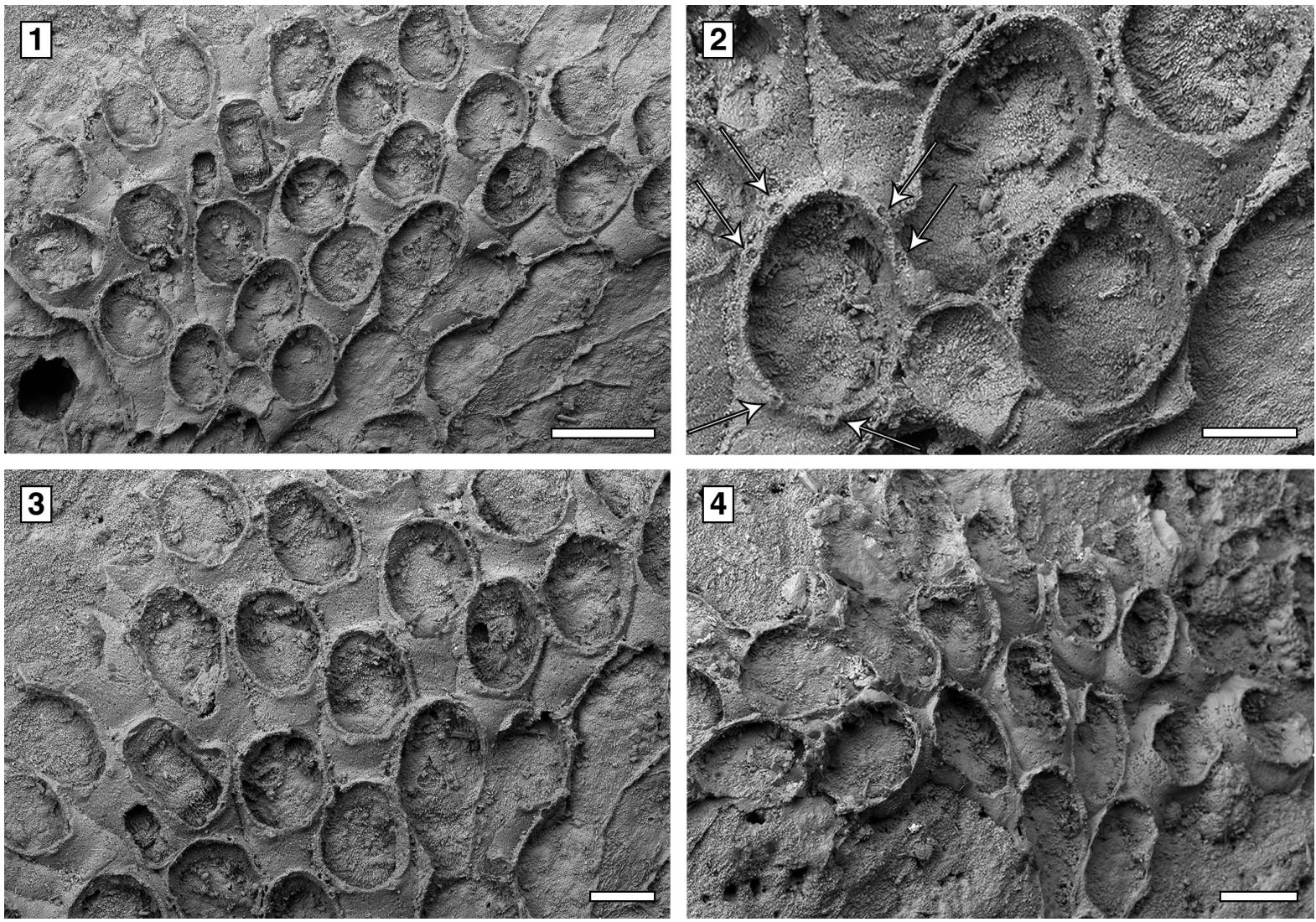

FIGURE 7. Osburnea aff. biscuta (Osburn, 1950), UF 305761a, b (Shell 374), Pliocene, lower Tamiami Formation Units 10/11. 1, general view of the small colony (a) $(400 \mu \mathrm{m})$. 2, close-up of autozooids with arrows showing two proximomedial and four distolateral spine bases $(200 \mu \mathrm{m})$. 3, group of autozooids including those at row bifurcation (200 $\mu \mathrm{m}) .4$, tilted view of small, fan-shaped colony (b) $(200 \mu \mathrm{m})$.

Family Electridae d'Orbigny, 1851

Genus Osburnea Nikulina, 2010

Osburnea aff. biscuta (Osburn, 1950)

Figure 7

aff. 1950 Electra biscuta Osburn, p. 37, pl. 3, figures 7, 8.

Figured material. UF 305761a, b (two small colonies) (Shell 374). Pliocene, lower Tamiami Formation.

Description. Colony encrusting, multiserial, unilaminar, forming fan-shaped patches (Figure 7.1, 4). Autozooids distinct with deep interzooidal grooves, quincuncially arranged, club-shaped, elongate (mean L/W 1.73) (Figure 7.2-3). Gymnocyst smooth, lacking pores or pits, narrow distally and laterally, extended proximally to about onequarter of the frontal surface, rarely two-thirds. Opesia extensive, elliptical, surrounded by an inconspicuous, crenulated rim of cryptocyst. Four spine bases distolaterally and two median spine bases proximally to the opesia on the gymnocyst indenting the cryptocystal rim, 25-30 $\mu \mathrm{m}$ in diame- ter (Figure 7.2, see arrows). Avicularia and kenozooids absent. Ancestrula not seen.

Measurements $(\mu \mathrm{m})$. ZL 536 $\pm 60,440-622(1,15)$;

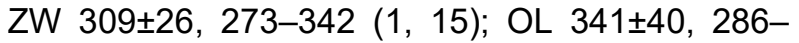
363 (1, 10); OW 271 $\pm 14,247-295(1,10)$.

Remarks. This species resembles the recent Osburnea biscuta (Osburn, 1950), from the Pacific coast of Panama, in having a gymnocyst commonly extended proximally to one-quarter of the frontal surface, four distolateral spines and more than a single proximomedial spine: the number of proximomedial spines in the Pliocene species is constantly two, while it varies from one to five in the recent species. Osburnea aff. biscuta also differs from the nominal species in having a less conspicuous cryptocyst surrounding the extensive opesia and, based on the size range reported in Osburn (1950), much larger zooids $(0.45-062 \mathrm{~mm}$ long by $0.27-0.34 \mathrm{~mm}$ wide vs $0.26-0.30 \mathrm{~mm}$ long by $0.18-0.22 \mathrm{~mm}$ wide in the fossil and recent species, respectively). The Osburnea biscuta species group is presently restricted to the Pacific coast of 
Panama. If the affinity of the Tamiami Formation species is confirmed, it may indicate a change in the biogeographical distribution driven by the closure of the Panamanian gateway. This is the second fossil record of Osburnea, the oldest being $O$. aquitanica (Nikulina and Taylor, 2009) reported from the Miocene of France.

Superfamily Calloporoidea Norman, 1903

Family Calloporidae Norman, 1903

Genus Amphiblestrum Gray, 1848

Amphiblestrum constrictum Ulrich and Bassler, 1904

Figure 8

1904 Amphiblestrum constrictum Ulrich and Bassler, p. 413, pl. 115, figures 6, 7, pl. 118, figure 15.

1923 Amphiblestrum constrictum Canu and Bassler, p. 44, pl. 13, figures 1-6.

1923 Amphiblestrum tenuiparietis Canu and Bassler, p. 45, pl. 13, figure 7.

Figured material. UF 305762 (Shell 5); UF 305763 (Shell 329); UF 305764 (Shell 28). Pliocene, lower Tamiami Formation.

Description. Colony encrusting, multiserial, unilaminar, sheet-like (Figure 8.1). Pore-chamber windows visible at colony growing edge (Figure 8.1, 3 ), a slightly larger one placed distally and two per side placed distolaterally, elliptical, 95-125 $\mu \mathrm{m}$ long by $35-40 \mu \mathrm{m}$ wide. Autozooids distinct with deep interzooidal furrows, arranged quincuncially, rounded hexagonal, slightly longer than wide (mean L/W 1.28). Gymnocyst inconspicuous, visible proximally and laterally on some zooids; cryptocyst elongate oval to pyriform, defined by a slightly raised, crenulated rim, extended usually one-quarter to one-third of zooidal frontal length, rarely half, granular, with granules aligned in rows radiating from the proximal margin of the opesia, reduced laterally and very narrow distally, sloping inwards. Opesia pear-shaped, constricted distolaterally by two stout, rounded, condyle-like projections of the cryptocyst. One or two distolateral oral spine bases present in some autozooids (Figure 8.4, see arrows). Adventitious avicularia columnar, placed on the proximolateral corner of most autozooids, pear-shaped (Figure 8.3, 5); rostrum rounded, proximolaterally or distolaterally directed; two stout condyles. Interzooidal avicularia absent. Ovicell hyperstomial, globular; endooecium calcified, granular, crescentic; ectooecium reduced to a marginal band of smooth calcification bordering the endooecium (Figure 8.6). Ancestrula tatiform with an uncertain number of circumopesial spines, ovoidal, about $380 \mu \mathrm{m}$ long by $320 \mu \mathrm{m}$ wide, surrounded by seven autozooids (Figure 8.2, 7); gymnocyst more developed proximally, tapering laterally, disappearing distally, but completely overgrown in large colonies by later autozooids; cryptocyst very narrow, crenulated; opesia subcircular, about $200 \mu \mathrm{m}$ in diameter. A distal (300-340 $\mu \mathrm{m}$ long by $150-250$ $\mu \mathrm{m}$ wide) and two distolateral zooids (310-410 $\mu \mathrm{m}$ long by $230-260 \mu \mathrm{m}$ wide) budded directly from the ancestrula, similar to later autozooids but smaller. Intramural buds and closure plates observed (Figure 8.4).

Measurements ( $\mu \mathrm{m})$. ZL 465 $\pm 34,406-523(2,20)$;

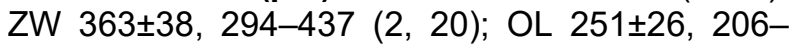
289 (2, 20); OW 223 $\pm 18,190-259$ (2, 20); AvL $133 \pm 12,112-149$ (2, 12); AvW 100 $\pm 9,89-119$ (2,

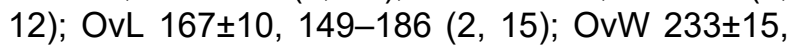
207-260 (2, 15).

Remarks. Amphiblestrum constrictum Ulrich and Bassler, 1904 was originally described from the Miocene St. Mary's Formation of Maryland and subsequently reported from the Pliocene of Virginia and the Pleistocene of South Carolina by Canu and Bassler (1923). Canu and Bassler (1923) also described a new species of Amphiblestrum from the Pliocene of Florida, A. tenuiparietis, distinguished from $A$. constrictum in having circumopesial spines in the ancestrula and distal opesial spines in the autozooids. However, SEM images of the holotype of $A$. constrictum (Figure 9.1-3; USNM 68459) revealed the presence of 1-4 distal opesial spine bases in some autozooids. Unfortunately, the ancestrula was not observed in the holotype of $A$. constrictum, but our Pliocene Florida specimens show that spines in the ancestrula are often masked owing to recrystallization or covered by the subsequently budded periancestrular autozooids. No other significant differences can be observed between these two species, and $A$. tenuiparietis (Figure 9.4-6; USNM 68460) is here considered to be a junior subjective synonym of $A$. constrictum. As Canu and Bassler (1923) already stated, intracolonial variability for species in this genus is high. Some variations we observed in both our specimens and the holotype of $A$. constrictum include: the direction of avicularia, which are mostly directed proximally and only exceptionally distally; the extension of the ectooecial calcification; and the presence/absence of spine bases and their number.

Genus Aplousina Canu and Bassler, 1927

Aplousina grandis (Canu and Bassler, 1923)

Figure 10

1923 Membrendoecium grande Canu and Bassler, p. 36 , pl. 11, figures 10-12. 

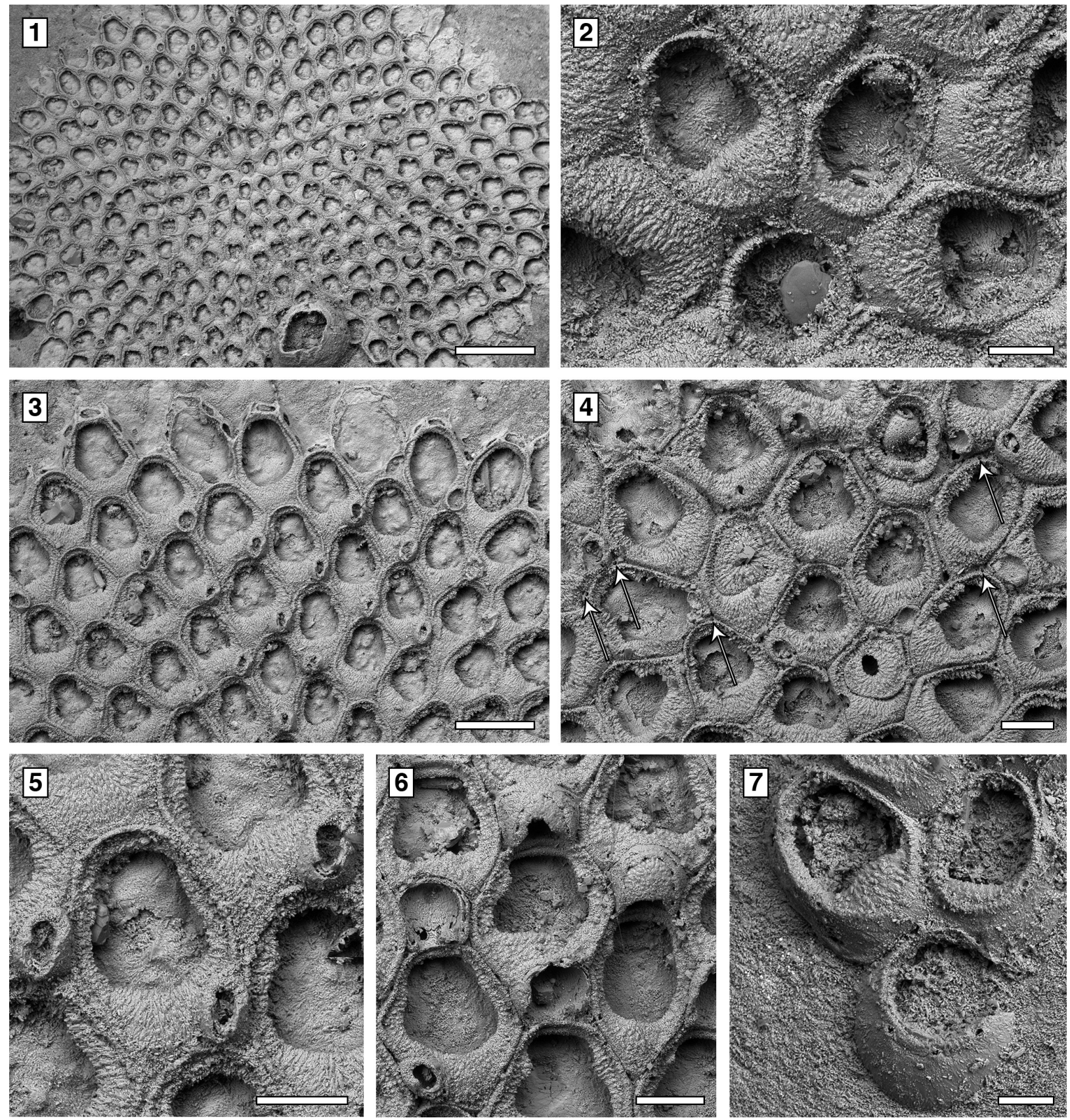

FIGURE 8. Amphiblestrum constrictum Ulrich and Bassler, 1904, Pliocene, lower Tamiami Formation Units 10/11. 13, UF 305762 (Shell 5). 1, general view of an extensive, circular, sheet-like colony overgrown by a barnacle (1 mm). 2, close-up of a partially overgrown tatiform ancestrula and first budded autozooids (100 $\mu \mathrm{m})$. 3, group of autozooids including colony growing edge, showing pore-chamber windows and adventitious avicularia (500 $\mu \mathrm{m})$. 4-6, UF 305763 (Shell 329). 4, group of autozooids showing intramural buds and closure plates (200 $\mu \mathrm{m})$, with arrows indicating distolateral oral spine bases. 5, close-up of adventitious avicularia $(200 \mu \mathrm{m})$. 6, group of ovicellate zooids (200 $\mu \mathrm{m})$. 7, UF 305764 (Shell 28), close-up of the tatiform ancestrula and first budded zooids (100 $\mu \mathrm{m})$.

Figured material. UF 305765 (Shell 13); UF 305766 (Shell 504). Pliocene, lower Tamiami Formation.

Description. Colony encrusting, multiserial, unilaminar, sheet-like (Figure 10.1). Pore-chambers lacking. Autozooids distinct with shallow interzooidal furrows, arranged quincuncially, highly variable in shape, from ovoidal to hexagonal, lozengeshaped or pear-shaped, very large, averaging 1.5 times longer than wide. Autozooids located at col- 

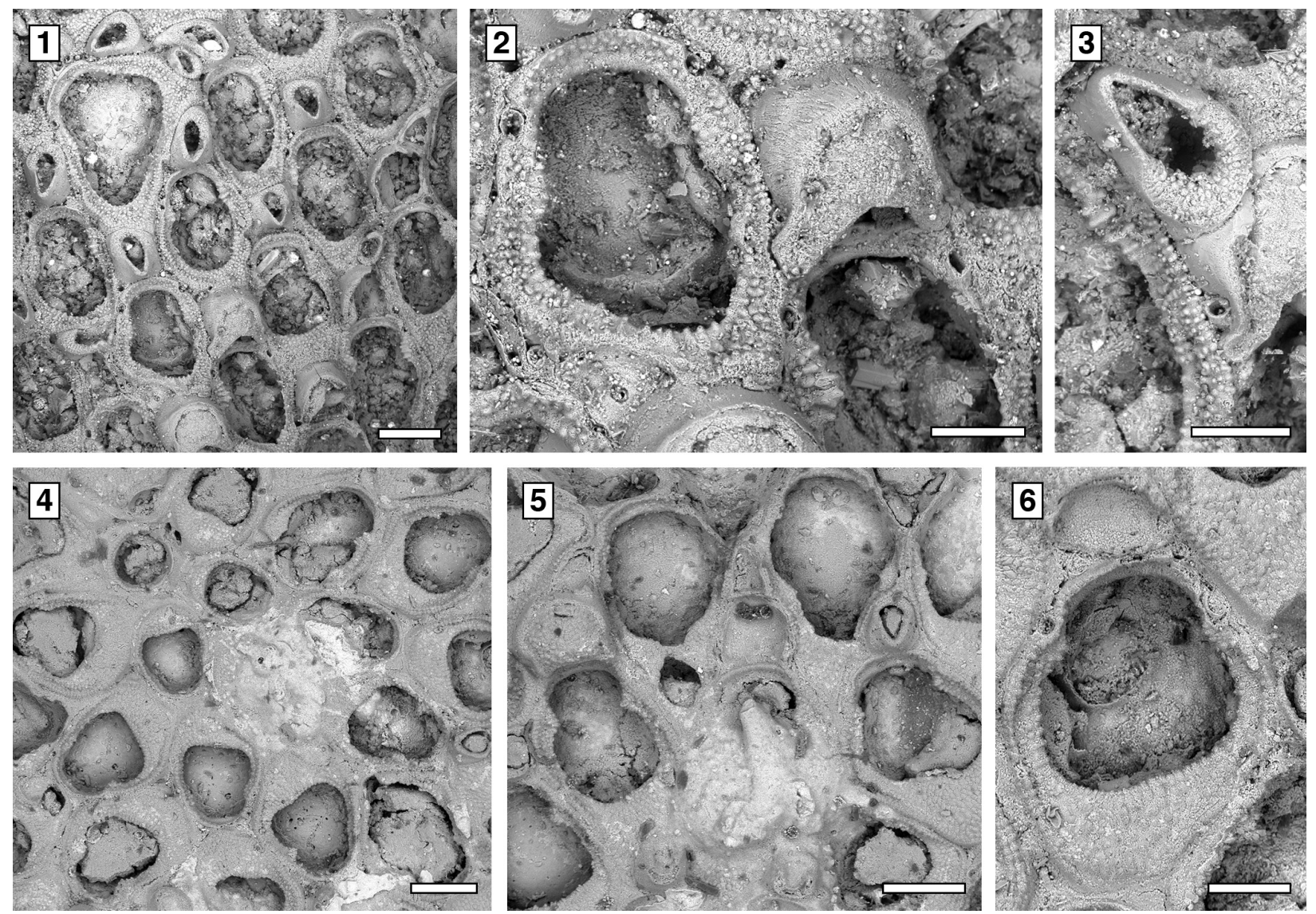

FIGURE 9. 1-3, Amphiblestrum constrictum Ulrich and Bassler, 1904, holotype USNM 68459, Miocene, Maryland, USA. 1, part of the colony $(200 \mu \mathrm{m})$. 2, close-up of an autozooid with four distolateral spine bases and an ovicell (100 $\mu \mathrm{m})$. 3, close-up of the adventitious avicularium (100 $\mu \mathrm{m})$. 4-6, Amphiblestrum tenuiparietis Canu and Bassler, 1923, holotype USNM 68460, Pliocene, Florida, USA. 4, part of the colony $(200 \mu \mathrm{m}) . \mathbf{5}$, close-up including autozooids, an ovicellate zooid and an adventitious avicularium $(200 \mu \mathrm{m})$. $\mathbf{6}$, close-up of a zooid with incomplete ovicell and distolateral spine bases $(100 \mu \mathrm{m})$.

ony bifurcation either paired and narrow with the two zooids as large as the preceding autozooid in the row, or irregularly shaped and much larger than the preceding autozooid in the row (Figure 10.2-3). Frontal surface almost entirely occupied by the opesia, which assumes the shape of the autozooid. A very narrow rim of smooth gymnocyst occasionally visible proximally and distally; a narrow, lowbeaded rim of cryptocyst encircling the opesia. Ovicell endozooidal, ooecium hood-like, granular (Figure 10.3). Avicularia and spines absent. Intramural buds common (Figure 10.2). Irregularly shaped kenozooids formed along the edges between contacting colonies (Figure 10.4). Ancestrula pearshaped, similar to later autozooids in size and in the development of the gymnocyst and the cryptocyst, budding one distal and two distolateral zooids (Figure 10.5-6). First budded zooids smaller than the ancestrula and later autozooids.
Measurements $(\boldsymbol{\mu m})$. ZL 786 $\pm 44,690-857(1,15)$;

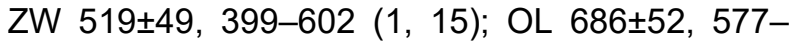
775 (1, 15); OW 446 \pm 33 , 383-509 (1, 15); OvL $153 \pm 12,128-168(1,15)$; OvW 340 $23,294-373$ $(1,15)$.

Remarks. Aplousina grandis was reported from the Pliocene Duplin Formation of North Carolina and the lower Pleistocene Waccamaw Formation of North Carolina (Canu and Bassler, 1923). The species was first attributed to the genus Membrendoecium Canu and Bassler, 1917, which was later placed in synonymy with Antropora Norman, 1903 by Silén (1941). In introducing the genus Aplousina in 1927, the authors referred this species to the new genus because of the lack of avicularia compared to other species included in Membrendoecium (Canu and Bassler, 1927, p. 3). A very similar species, Aplousina gigantea Canu and Bassler, $1928 \mathrm{a}$, is at the present day very abundant in the eastern Gulf of Mexico and the Straits of Florida 

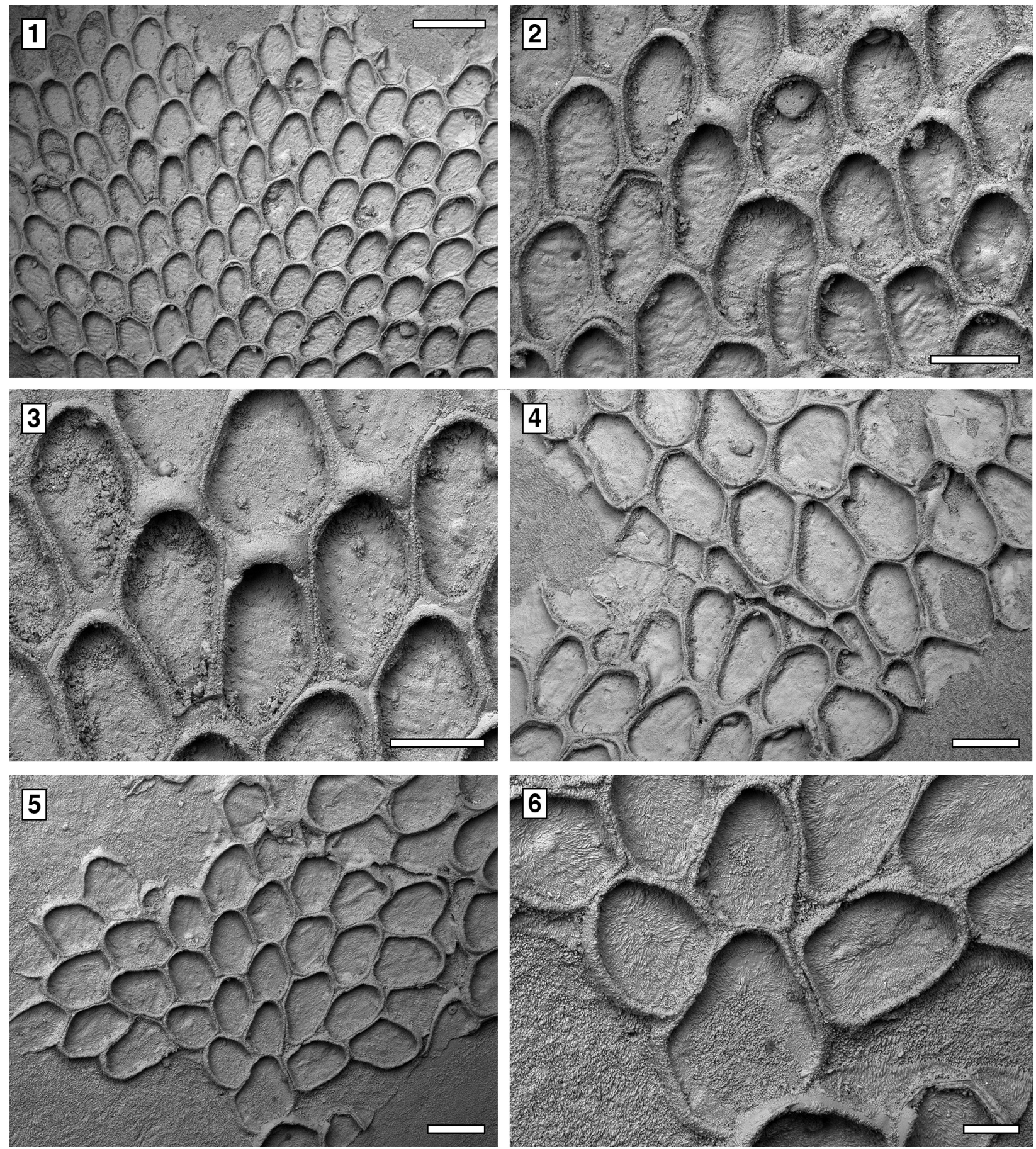

FIGURE 10. Aplousina grandis (Canu and Bassler, 1923), Pliocene, lower Tamiami Formation Units 10/11. 1-3, UF 305765 (Shell 13). 1, general view of an extensive, sheet-like colony (1 mm). 2, group of ovicellate and non-ovicellate zooids, some with intramural buds $(500 \mu \mathrm{m})$. 3, close-up of three ovicellate zooids $(400 \mu \mathrm{m})$. 4-6, UF 305766 (Shell 504). 4, irregularly shaped kenozooids formed along the encounter edge of two colonies (500 $\mu \mathrm{m}) . \mathbf{5}$, small colony with ancestrula $(500 \mu \mathrm{m}) .6$, close-up of the ancestrula and first budded autozooids $(200 \mu \mathrm{m})$. 

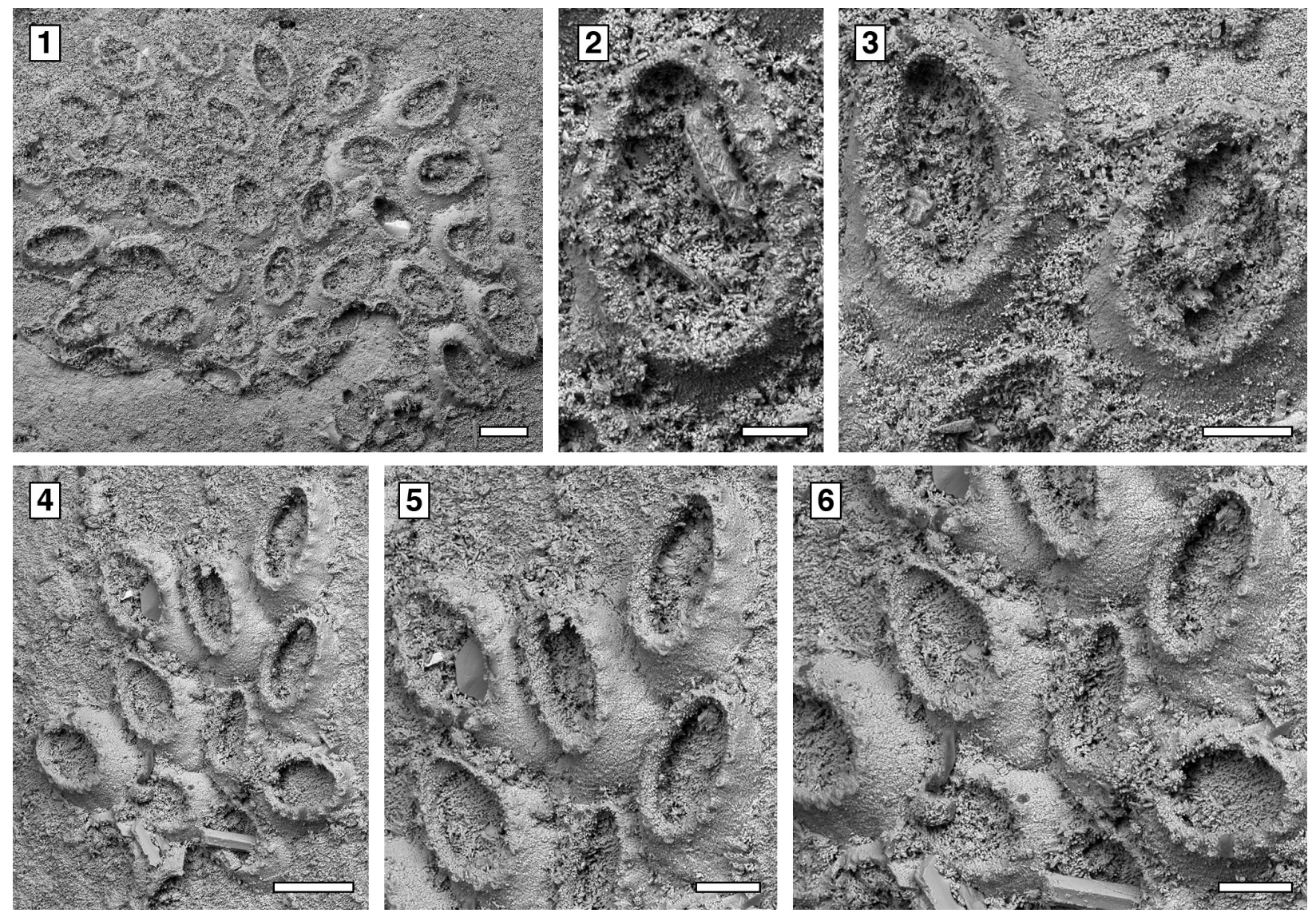

FIGURE 11. Cauloramphus? sp., UF 305767a, b (Shell 324), Pliocene, lower Tamiami Formation Units 10/11. 1, general view of the small colony (a) $(200 \mu \mathrm{m})$. 2, close-up of an autozooid showing the numerous circumopesial spine bases $(60 \mu \mathrm{m}) .3$, close-up of two autozooids with a large gap in between likely to have been occupied by the connecting tubular chambers typical of some species of Cauloramphus $(100 \mu \mathrm{m}) .4$, tilted view of small colony (b) (200 $\mu \mathrm{m})$. $\mathbf{5}$, group of tilted autozooids, the top right autozooid showing cut-off tubular chambers on the lateral walls $(100 \mu \mathrm{m})$. $\mathbf{6}$, close-up of some autozooids $(100 \mu \mathrm{m})$.

(Winston, 2016). Canu and Bassler (1928a) distinguished $A$. grandis from $A$. gigantea based on zooid size, with zooids larger in the living species than in the fossil. However, the zooid size range in fossil specimens overlaps with that of recent material. Additional differences are the shape of the zooids, highly variable in $A$. grandis, but consistently lozenge-shaped in $A$. gigantea, and the greater thickness of the walls in the fossil species compared to the modern.

\section{Genus Cauloramphus Norman, 1903 Cauloramphus? sp.}

Figure 11

Figured material. UF 305767a, b (two small colonies) (Shell 324). Pliocene, lower Tamiami Formation.

Description. Colony encrusting, multiserial, unilaminar (Figure 11.1, 4). Autozooids distinct, delineated by conspicuous interzooidal furrows, irregularly arranged, oval, longer than wide (mean L/W 1.59). Gymnocyst smooth, convex, broad and sloping proximally and laterally; cryptocyst a nearly vertical shelf, granular, narrow. Opesia extensive, occupying most of the zooidal frontal surface, oval, surrounded by an uncertain number of oral spine bases (seemingly about 17-18), 14-20 $\mu \mathrm{m}$ in diameter (Figure 11.2-3, 11.5-6). Avicularia, ovicells and ancestrula not observed.

Measurements $(\mu \mathrm{m})$. ZL 370 \pm 35 , 324-450 $(2,15)$; ZW 233 \pm 32 , 176-278 (2, 15); OL 254 $28,205-$ 309 (2, 15); OW 149 $\pm 21,117-193(2,15)$.

Remarks. The only two specimens of Cauloramphus? sp. (Figure 11.1, 11.4) found, encrust the same Anomia shell. The colonies are small, with 25 and 11 zooids preserved, respectively. Unfortunately, the poor preservation prevents clear observation of the connections among autozooids, but it is apparent from some zooids that they are connected via narrow tubular chambers spaced out 

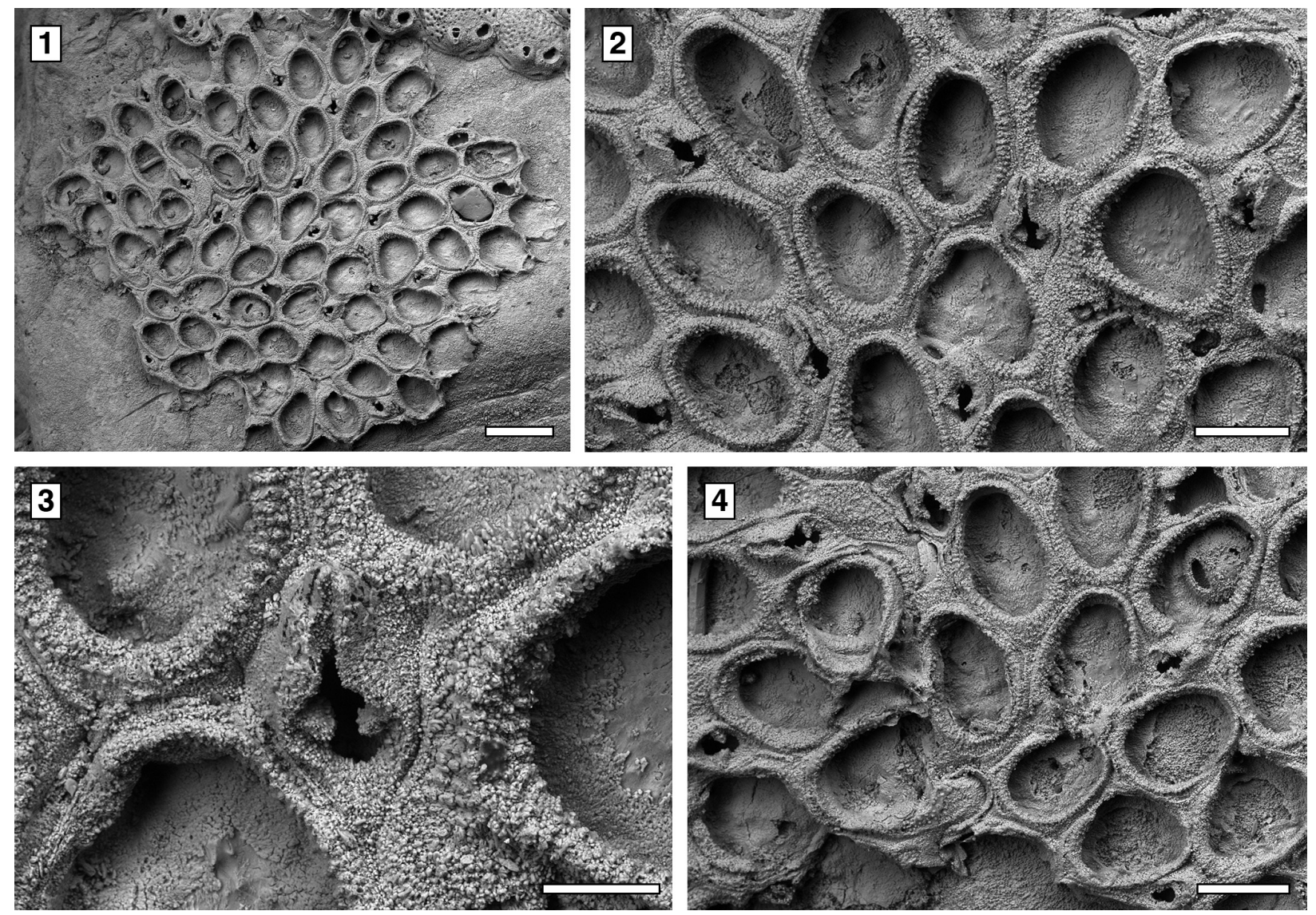

FIGURE 12. Copidozoum cf. parvirostris (Canu and Bassler, 1923) comb. nov., UF 305768 (Shell 12), Pliocene, lower Tamiami Formation Units 10/11. 1, general view of the colony $(400 \mu \mathrm{m})$. 2, group of autozooids and interzooidal avicularia $(200 \mu \mathrm{m})$. 3, close-up of an interzooidal avicularium $(100 \mu \mathrm{m}) .4$, intramural buds $(200 \mu \mathrm{m})$.

with lacunae (Figure 11.5). The recent Cauloramphus opertus Canu and Bassler, 1928a from the Gulf of Mexico is similar in size to the fossil species. It is characterized by having 20 opesial spines forming a costate frontal shield plus four erect orificial spines and long, pedunculate, horn-shaped avicularia. Because of both preservation and small size of the colonies available in the Tamiami Formation material, we are unable to observe the original spine arrangement and we cannot rule out the former presence of pedunculate avicularia in this species. An alternative attribution would be to Retevirgula Brown, 1948, but this genus has ovicells, which have not been observed in the scant material available.

Genus Copidozoum Harmer, 1926

Copidozoum cf. parvirostris (Canu and Bassler, 1923) comb. nov.

Figure 12

cf. 1923 Callopora parvirostris Canu and Bassler, p. 41 , pl. 12, figure 3 .
Figured material. UF 305768 (Shell 12). Pliocene, lower Tamiami Formation.

Description. Colony encrusting, multiserial, unilaminar (Figure 12.1). Pore-chamber windows present (Figure 12.2). Autozooids distinct with deep interzooidal furrows, quincuncially arranged, oval to rounded polygonal, longer than wide (mean L/W 1.37). Gymnocyst extremely reduced and discontinuously visible only along the margins of some zooids; cryptocyst narrow, forming a raised mural rim encircling the opesia, coarsely granular with a striated appearance owing to the granules aligned in radial rows, then sloping steeply inwards. Opesia extensive, occupying most of the zooidal frontal surface, variable in shape from oval to elliptical or pear-shaped. Spine bases absent. Avicularia interzooidal, frequent, scattered throughout the colony, placed on a rhomboidal cystid (Figure 12.3); gymnocyst more developed laterally; rostrum raised, acicular, directed distally; two robust condyles as pivots. Ovicells not observed. Intramural buds 
present in both zooids and avicularia (Figure 12.34). Ancestrula not seen.

Measurements $(\mu \mathrm{m})$. ZL 373 \pm 35 , 337-427 $(1,10)$;

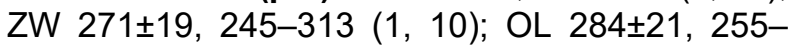
315 (1, 10); OW 185 $\pm 17,158-217$ (1, 10); AvL

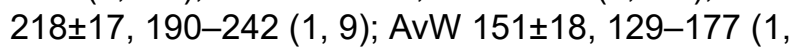
9).

Remarks. As already noted by Echols (1960), Callopora parvirostris Canu and Bassler, 1923, from the Miocene of Maryland is very similar to $C$. tenuirostre, the main difference being the greater size of the zooids. Canu and Bassler (1923) also distinguished Callopora parvirostris from Copidozoum tenuirostre based on the size of the interzooidal avicularia, which they stated is much smaller in the former species compared to the latter species. Unfortunately, Canu and Bassler (1923) failed to provide a size range for the avicularia in C. parvirostris. However, based on the image provided (Canu and Bassler, 1923, pl. 12, figure 3), the length of an avicularium seems to be about half the length of a zooid (ZL $0.55-0.60 \mathrm{~mm}$ ), thus the avicularia in the holotype of $C$. parvirostris are about the same size of the avicularia in C. cf. parvirostris from the Tamiami Formation. The Tamiami Formation specimen differs from the holotype in having smaller autozooids (ZL $0.34-0.43 \mathrm{~mm}$ versus $0.55-0.60 \mathrm{~mm}$ ).

Superfamily Microporoidea Gray, 1848

Family Onychocellidae Jullien, 1882 Genus Floridina Jullien, 1882

Floridina regularis Canu and Bassler, 1923

Figure 13

1923 Floridina regularis Canu and Bassler, p. 57, pl. 14, figures 7, 8.

2008 Floridina regularis Knowles, p. 87, figures 3.1, 4.1-4.5.

2018 Floridina regularis Taylor et al., figure 11c, d.

Figured material. UF 305769 (Shell 1); UF 305770 (Shell 18); UF 305771 (Shell 22); UF 305772 (Shell 24); UF 305773 (Shell 324). Pliocene, lower Tamiami Formation.

Description. Colony encrusting, multiserial, uni- to multilaminar (Figure 13.1, 3). Autozooids distinct with shallow interzooidal furrows, quincuncially arranged, subhexagonal with rounded distal margin and straight to slightly concave, sometimes undulose, proximal margin, longer than wide (mean L/W 1.23). Gymnocyst minimal, sometimes visible along the zooidal proximal margin. Cryptocystal shelf occupying about half of zooidal frontal length, coarsely granular, depressed centrally, and raised at the edges, which appear striated because of finer, densely aligned granules. Opesia bell- shaped with straight or slightly concave proximal margin, rarely trifoliate with lateral opesiules or a convex proximal margin. Oral spines absent. A very narrow, granular cryptocystal shelf sometimes visible projecting proximally from the distal margin of the opesia. Vicarious avicularia infrequent, longer than autozooids, lozenge-shaped or subpentagonal (Figure 13.2); rostrum slightly raised, rounded triangular, laterally showing a narrow band of smooth gymnocyst; opesia placed centrally, ovoidal to elliptical; cryptocyst coarsely granular and depressed centrally as in autozooids; granules surrounding the opesia give a denticulate appearance to the outline. Ovicellate zooids slightly larger than autozooids; opesia generally larger than in autozooids and more elongate (mean L/W 1.54 vs 1.41 in autozooids) and with the distal edge formed by the cryptocyst of the next distal zooid (Figure 13.3). Irregularly shaped kenozooids, variable in size, observed along the edges of two abutting colonies (Figure 13.4); cryptocyst as in autozooids, variably developed; opesia located centrally, variable in size and shape. Ancestrula similar to later autozooids but smaller, $260-265 \mu \mathrm{m}$ long by 210 $215 \mu \mathrm{m}$ wide; opesia bell-shaped, 85-115 $\mu \mathrm{m}$ long by $115-130 \mu \mathrm{m}$ wide proximal to constrictions, $90-$ $115 \mu \mathrm{m}$ wide distal to constrictions (Figure 13.5); surrounded by six autozooids. One distal and two distolateral zooids budded directly from the ancestrula, 230-300 $\mu \mathrm{m}$ long by 195-240 $\mu \mathrm{m}$ wide and bell-shaped opesia 105-115 $\mu \mathrm{m}$ long by $110-120$ $\mu \mathrm{m}$ proximally and $85-95 \mu \mathrm{m}$ wide distally. Reparative structures often observed in autozooids (Figure 13.6). Closure plates with scars of the operculum observed in some colonies (Figure 13.7).

Measurements ( $\mu \mathrm{m})$. ZL 385 $\pm 24,341-429(2,20)$; ZW 313 $\pm 20,275-337$ (2, 20); OL 155 $\pm 6,141-164$ (2, 20); OWmin 110 $\pm 9,93-120$ (2, 20); OWmax

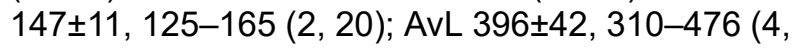
20); AvW 213 \pm 41 , 169-343 (4, 20); AvOpL 150 $\pm 28,96-194$ (4, 20); AvOpW 75 $\pm 22,41-119$ (4, 20); ZL* 414 $\pm 62,331-552(3,10) ; \mathrm{ZW}^{*} 329 \pm 60$, 253-430 (3, 10); OL* 222 ${ }^{*} 17,193-243(3,10)$; $\mathrm{OW}^{*} \min \quad 144 \pm 4, \quad 138-151 \quad(3,10) ; \quad \mathrm{OW}^{*} \max$ 183 $\pm 10,169-206$ (3, 10). *Maternal zooids.

Remarks. Floridina regularis was first described from the Pliocene Duplin Formation of North Carolina (Canu and Bassler, 1923) and later found in other North American Pliocene and Pleistocene deposits, including the upper Tamiami Formation of Florida, varying in abundance (Knowles, 2008). On the Anomia shells, F. regularis is extremely abundant (see Table 1). Floridina regularis differs from 

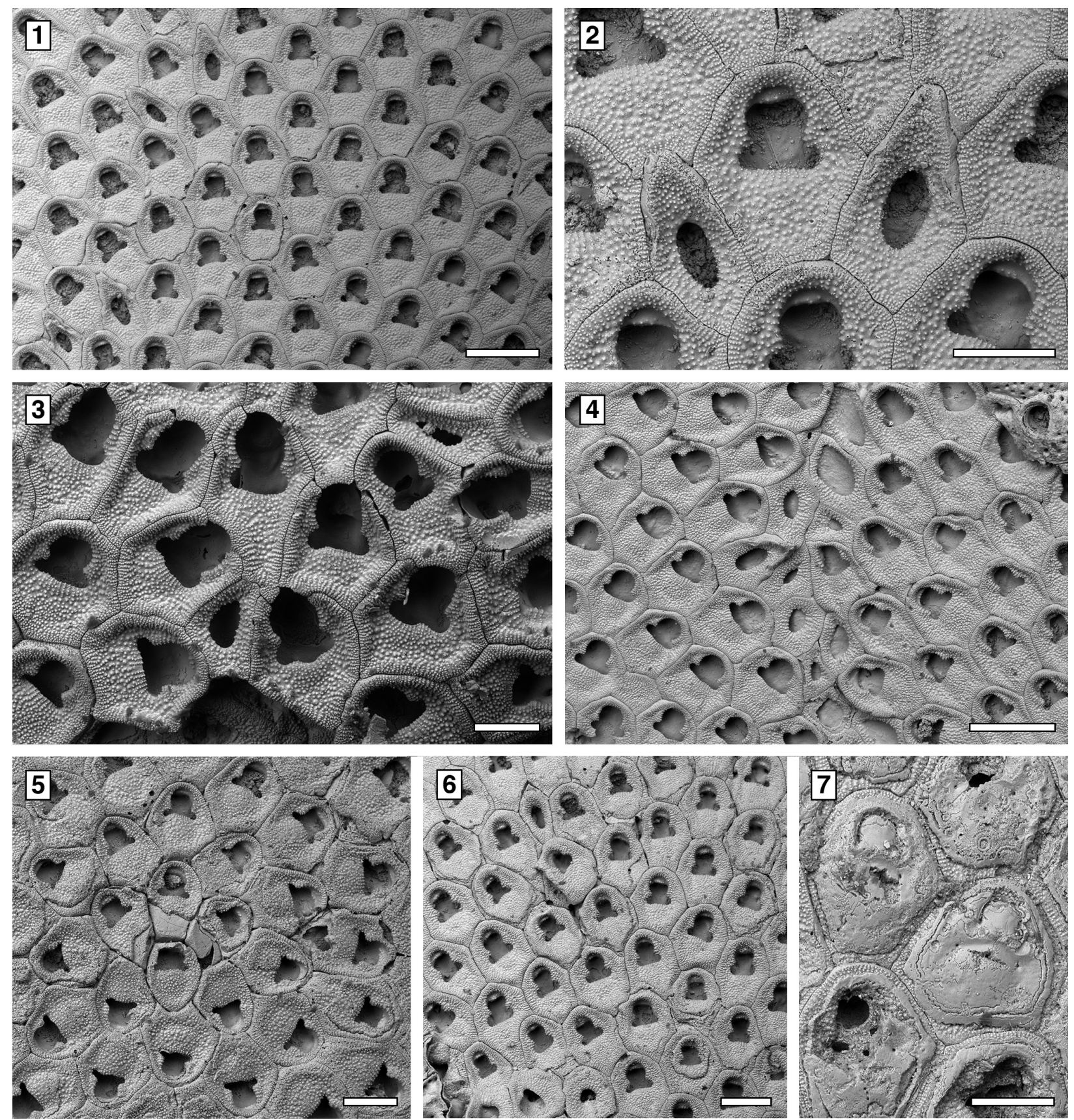

FIGURE 13. Floridina regularis Canu and Bassler, 1923, Pliocene, lower Tamiami Formation Units 10/11. 1-2, UF 305769 (Shell 1). 1, group of autozooids and vicarious avicularia (400 $\mu \mathrm{m}) .2$, close-up of an autozooid flanked by

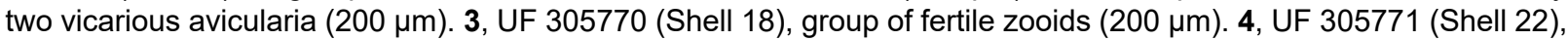
irregularly shaped kenozooids formed at the encounter edge between two abutting colonies (400 $\mu \mathrm{m}) .5$, UF 305772 (Shell 24), ancestrula and early astogeny (300 $\mu \mathrm{m})$. 6, UF 305770 (Shell 18), intramural buds (200 $\mu \mathrm{m})$. 7, UF 305773 (Shell 324), closure plates with scars of the operculum $(200 \mu \mathrm{m})$.

F. antiqua (Smitt, 1873), the type species of the genus, in having more-angular zooids and a lesspronounced curvature of the proximal margin of the opesia, which often appears more bell-shaped than trifoliate. It also differs from F. subantiqua Di Martino, Taylor, and Portell, 2017 from the Chipola For- mation of Florida in having smaller autozooids and vicarious avicularia lacking lateral constrictions.

Family Microporidae Gray, 1848 Genus Micropora Gray, 1848 Micropora stellata sp. nov.

Figure 14 
TABLE 1. List of bryozoan species with abundances (number of colonies) found in Units 10/11 of the upper Pliocene lower Tamiami Formation of Florida, USA.

\begin{tabular}{|c|c|c|c|}
\hline & Species & Authors & $\begin{array}{c}\text { No. } \\
\text { colonies }\end{array}$ \\
\hline 1 & Acanthodesia cf. denticulata & (Busk, 1856) & 1 \\
\hline 2 & Acanthodesia sp. & - & 11 \\
\hline 3 & Amphiblestrum constrictum & Ulrich and Bassler, 1904 & 109 \\
\hline 4 & Aplousina grandis & (Canu and Bassler, 1923) & 165 \\
\hline 5 & Cauloramphus? sp. & - & 3 \\
\hline 6 & Celleporaria sp. & Canu and Bassler, 1923 & 24 \\
\hline 7 & Copidozoum cf. parvirostris & (Canu and Bassler, 1923) & 8 \\
\hline 8 & Cyclocolposa perforata & Canu and Bassler, 1923 & 247 \\
\hline 9 & Cycloperiella rubra & Canu and Bassler, 1923 & 94 \\
\hline 10 & Floridina regularis & Canu and Bassler, 1923 & 554 \\
\hline 11 & Hippaliosina rostrigera & (Smitt, 1873) & 7 \\
\hline 12 & Hippopleurifera mucronata & (Smitt, 1873) & 51 \\
\hline 13 & Metroperiella reversa & (Ulrich and Bassler, 1904) & 190 \\
\hline 14 & Micropora stellata & sp. nov. & 9 \\
\hline 15 & Microporella cf. protea & Winston, 2005 & 1364 \\
\hline 16 & Microporella sarasotaensis & sp. nov. & 592 \\
\hline 17 & Microporella tamiamiensis & sp. nov. & 446 \\
\hline 18 & Oncousoecia? sp. & - & 9 \\
\hline 19 & Osburnea aff. biscuta & (Osburn, 1950) & 3 \\
\hline 20 & Plesiocleidochasma cf. vestitum & (Canu and Bassler, 1923) & 106 \\
\hline 21 & Pourtalesella chiarae & sp. nov. & 510 \\
\hline 22 & Puellina scripta? & (Reuss, 1848) & 917 \\
\hline 23 & Reptadeonella umbilicata & (Lonsdale, 1845) & 109 \\
\hline 24 & Smittoidea maleposita & (Canu and Bassler, 1923) & 25 \\
\hline 25 & Spiniflabellum laurae & sp. nov. & 2 \\
\hline 26 & Stephanollina vorax & (Canu and Bassler, 1923) & 78 \\
\hline 27 & Stylopoma leverhulme & Di Martino, Taylor and Portell, 2017 & 13 \\
\hline 28 & Trypostega composita & sp. nov. & 97 \\
\hline 29 & Watersipora? sp. & - & 9 \\
\hline
\end{tabular}

\section{zoobank.org/B79808D0-B0FC-4C7A-84E5-C29ACF4EF654}

Type material. Holotype UF 305774 (Shell 33); paratype UF 305775 (Shell 31). Pliocene, lower Tamiami Formation.

Etymology. From the Latin 'stellatus, -a, -um' meaning 'starry, with stars', referring to the finely denticulate, star-shaped pseudopores in the frontal shield.

Diagnosis. Colony encrusting; autozooids rhomboidal to hexagonal. Pore-chamber windows present. Frontal shield granulated and irregularly pseudoporous; pseudopores star-shaped because of a radiating denticulation. Opesiules paired, symmetrical, bordered by a raised margin, proximolateral to orifice. Orifice transversely D-shaped with a prominent knob on each side. Oral spines absent. Avicularia interzooidal, distal to the orifice in nonovicellate zooids, proximolaterally directed, crossbar complete. Ovicells with median, chevronshaped suture, smooth and a tubercle.

Description. Colony encrusting, multiserial, unilaminar. Pore-chamber windows visible at colony growing edge (Figure 14.1) or along the perimeter of broken autozooids, numerous, closely spaced in a continuous row all along the zooidal margin, elliptical, $30-45 \mu \mathrm{m}$ long by $20-25 \mu \mathrm{m}$ wide. Autozooids distinct, outlined by a thin interzooidal incision and a slightly raised, thickened (about $30 \mu \mathrm{m}$ ), granulated margin most pronounced where it borders the opesiules (Figure 14.2), quincuncially 

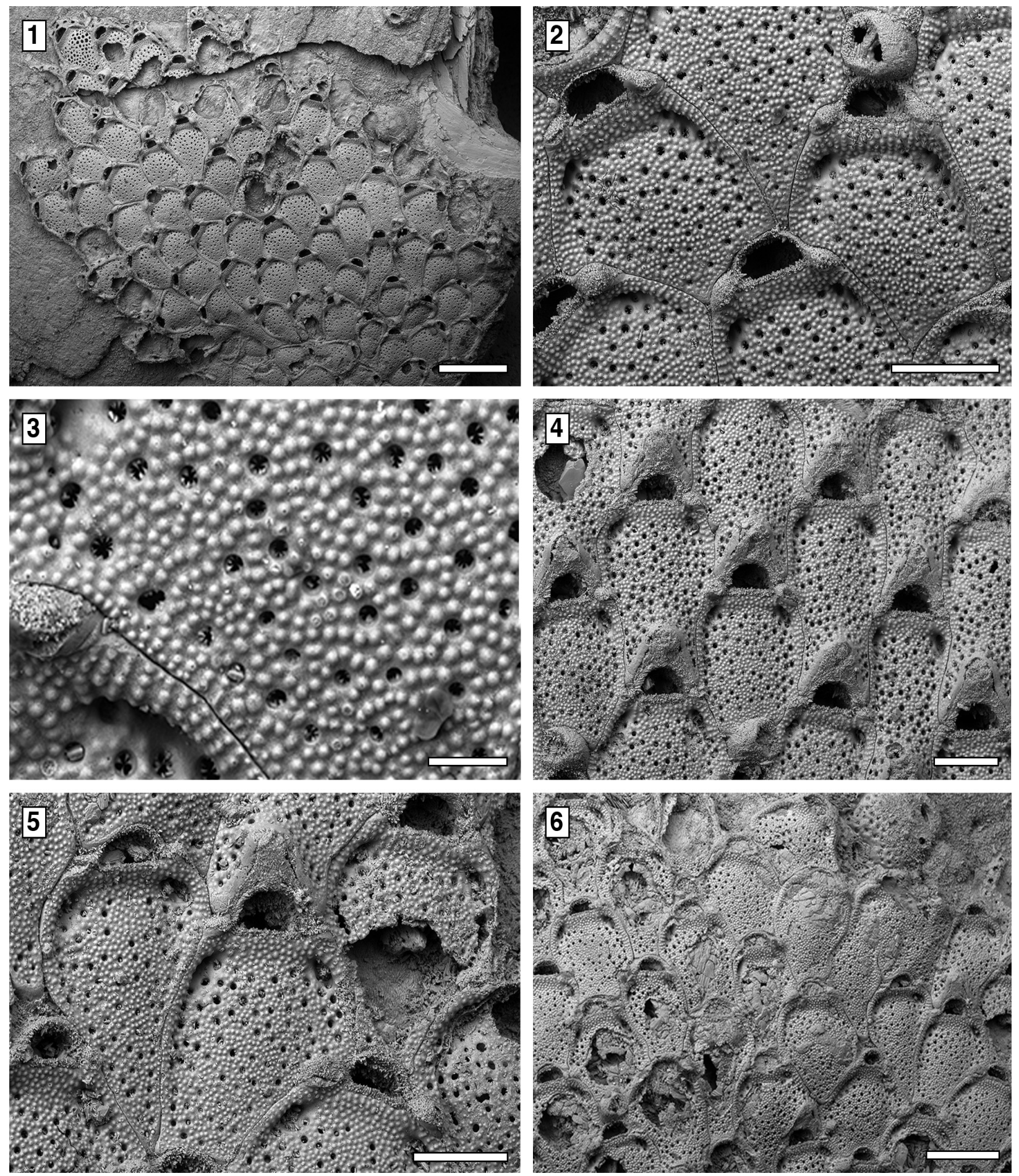

FIGURE 14. Micropora stellata sp. nov., Pliocene, lower Tamiami Formation Units 10/11. 1-3, paratype UF 305775 (Shell 31). 1, general view of the colony $(600 \mu \mathrm{m})$. 2, close-up of two autozooids with prominent knobs on each side of the orifice and a distal, interzooidal avicularium $(200 \mu \mathrm{m})$. 3, close-up of pseudopores with radiating denticulation giving them a star-shaped appearance $(50 \mu \mathrm{m}$ ). 4-6, holotype UF 305774 (Shell 33). 4, group of ovicellate zooids (200 $\mu \mathrm{m}) . \mathbf{5}$, close-up of an ovicellate zooid $(200 \mu \mathrm{m}) . \mathbf{6}$, part of the colony with closure plates $(400 \mu \mathrm{m})$. 
arranged, rounded rhomboidal to irregularly hexagonal, longer than wide (mean L/W 1.32). Frontal shield flat to slightly convex, finely granulated, irregularly pseudoporous and with paired opesiules; pseudopores 30-65 (on average 50) unevenly scattered throughout the frontal, rounded, 8-12 $\mu \mathrm{m}$ in diameter, with radiating denticulation giving them a star-shaped appearance (Figure 14.3); opesiules bean- to spindle-shaped, symmetrical, 50-80 $\mu \mathrm{m}$ long by $20-25 \mu \mathrm{m}$ wide, placed proximolateral to the orifice. Orifice transversely D-shaped, broader than long, elevated from the frontal surface, which starts to become raised below its proximal margin, forming an imperforate, coarsely granular, sloping shelf about 60-70 $\mu \mathrm{m}$ wide; a smooth, prominent knob, 50-70 $\mu \mathrm{m}$ in diameter, flanking the orifice on each side in most ovicellate and non-ovicellate zooids (Figure 14.2, 4). Oral spines absent; closure plates observed (Figure 14.6). Avicularia interzooidal, usually lying distal to the orifice in non-ovicellate zooids, on a raised, sloping, smooth cystid, almost elliptical in outline (Figure 14.1-2); rostrum triangular, occupying most of the raised top of the cystid, proximolaterally directed, either on the left or right; crossbar complete. Ovicells partly immersed in the frontal shield of the next distal zooid, with a median, chevron-shaped, smooth suture terminating in an apical tubercle (Figure 14.4-5). Intramural buds observed. Ancestrula not seen.

Measurements ( $\mu \mathrm{m})$. ZL 504 $\pm 46,410-573(2,20)$;

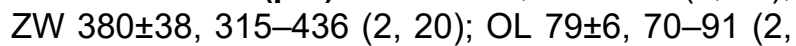

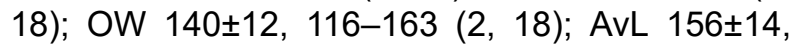
135-187 (2, 15); AvW 109 $\pm 8,97-126$ (2, 15); OvL

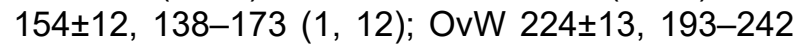
(1, 12).

Remarks. For their Neogene North American specimens, Canu and Bassler (1923) used the name Micropora coriacea (Esper, 1791), a European species that, since its first description, has been recorded worldwide at all latitudes and depths, both living and fossil. The advent of the SEM has helped to disentangle this complex of species, showing consistent differences in skeletal characters of material from different geological ages, regions, and habitats. Winston (2005) distinguished the western Atlantic material previously attributed to $M$. coriacea as the new species $M$. acuminata, which mainly differs from the new Tamiami Formation species in having a pointed tip to the ovicell suture. Micropora angustiscapulis Winston, Vieira, and Woollacott, 2014 from southwest Brazil is similar in having star-shaped pseudopores and robust knobs flanking the orifice but differs in having smaller autozooids (342-450 $\mu \mathrm{m}$ long by 234-360 $\mu \mathrm{m}$ wide vs 410-573 $\mu \mathrm{m}$ long by 315-436 $\mu \mathrm{m}$ wide) and smaller orifices (45-54 $\mu \mathrm{m}$ long by 90-108 $\mu \mathrm{m}$ wide vs 70-91 $\mu \mathrm{m}$ long by 116-163 $\mu \mathrm{m}$ wide); unfortunately, the holotype and only specimen available of $M$. angustiscapulis lacks avicularia and ovicells, essential features for a more thorough comparison. Star-shaped pseudopores were also observed in Micropora robusta Cook, 1985 (NHMUK 1972.3.3.1; Figure 15.1-2) from west Africa, but this species differs in having a larger orifice, finer granules on the frontal shield, and interzooidal avicularia that are directed distolaterally. Large, robust knobs are present in Micropora nodimagna Ramalho and Calliari, 2015 from southern Brazil, which differs from the Tamiami Formation species in the shape of the ovicell, which is squat, more prominent and has a broader, triangular suture of smooth calcification. The fossil specimen of Micropora coriacea sensu Canu and Bassler (1923) from the Pleistocene of California (USNM 68480; Figure 15.3-4) differs from the new species in having interzooidal avicularia directed distolaterally and rounded pseudopores lacking denticulation, although the latter character may be dependent on the quality of preservation.

Superfamily Cribrilinoidea Hincks, 1879

Family Cribrilinidae Hincks, 1879

Genus Puellina Jullien, 1886

Puellina scripta (Reuss, 1848)

Figures 16-18

1848 Cellepora scripta Reuss, p. 82, pl. 9, figure 28.

1923 Puellina radiata forma scripta Canu and Bassler, p. 89 , pl. 15, figure 12, pl. 35, figure 1.

1987 Puellina scripta Bishop and Househam, p. 58, figures 98, 99.

Figured material. UF 305776 (Shell 10); UF 305777 (Shell 343); UF 305778 (Shell 22); UF 305779 (Shell 3). Pliocene, lower Tamiami Formation.

Description. Colony encrusting, multiserial, unilaminar, developing extensive sheets ( $>200$ zooids) (Figure 16.1). Pore-chamber windows visible at colony growing edge, all along zooidal margins, numerous, closely spaced, rounded to elliptical, 30-45 $\mu \mathrm{m}$ long by $20-35 \mu \mathrm{m}$ wide (Figure 17.4). Autozooids distinct with deep interzooidal furrows, quincuncially arranged, oval to rounded hexagonal, longer than broad (mean L/W 1.43). Gymnocyst generally negligible but more extensive proximally in some zooids (Figure 17.1-3). Frontal shield flat, formed by 12-18 (within colony com- 

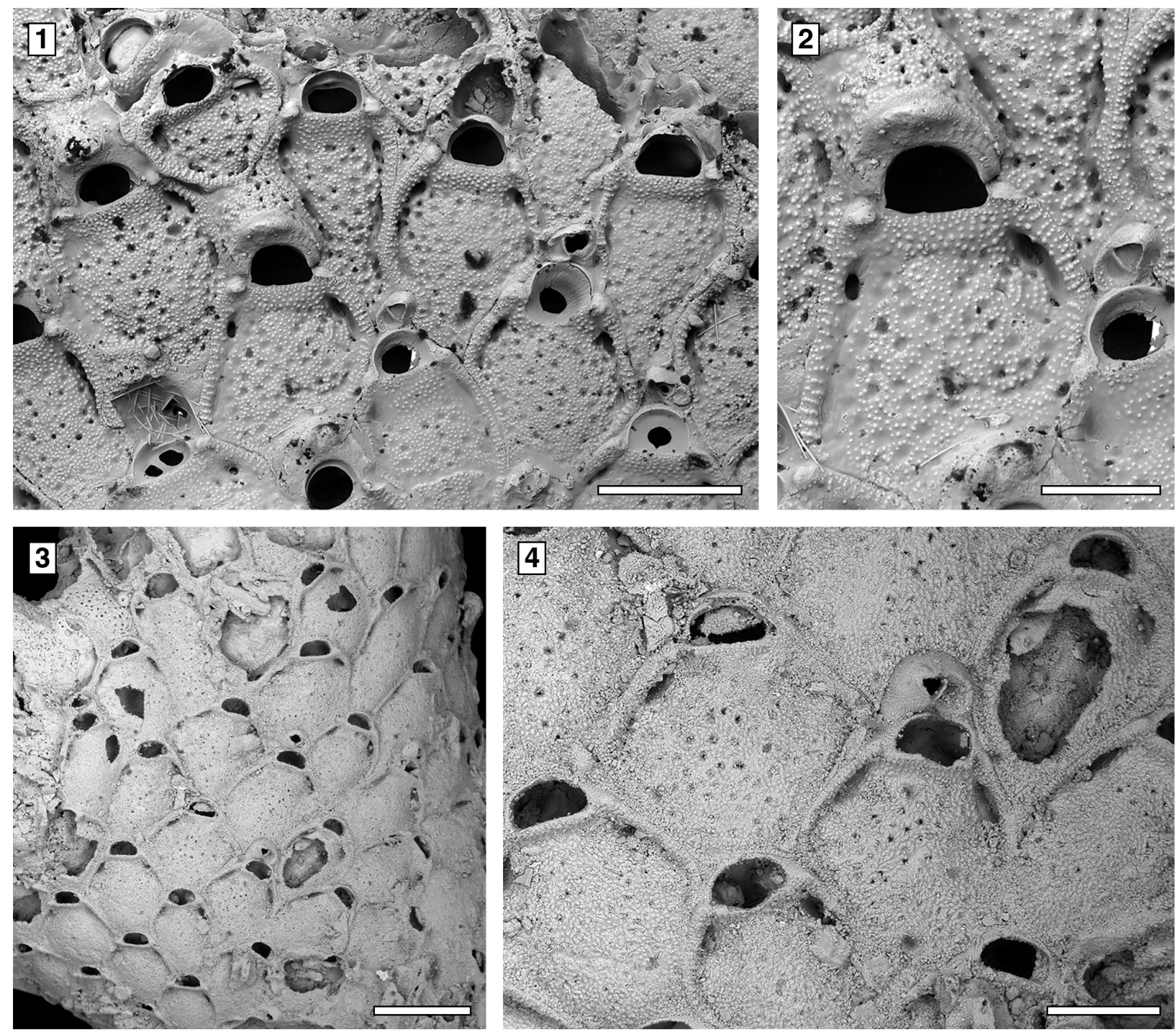

FIGURE 15. 1-2, Micropora robusta Cook, 1985, holotype NHMUK 1972.3.3.1, Recent, off Cape Coast, Ghana (27 m depth). 1, group of ovicellate and non-ovicellate zooids, some with closure plates, and interzooidal avicularia (400 $\mu \mathrm{m}) .2$, close-up of an ovicellate zooid and an interzooidal avicularium (200 $\mu \mathrm{m})$. 3-4, Micropora coriacea sensu Canu and Bassler (1923), USNM 68480, Pleistocene, California, USA. 3, group of autozooids and interzooidal avicularia $(500 \mu \mathrm{m}) .4$, close-up of some autozooids and an interzooidal avicularium $(200 \mu \mathrm{m})$.

monly 13 , exceptionally $17-18$ ) fused costae, 30$50 \mu \mathrm{m}$ at the largest tip, with usually four rounded intercostal lacunae, about $5 \mu \mathrm{m}$ in diameter. Distal pair of costae (apertural bar) joined medially, outlining a short triangular area and forming a scarcely developed, median, suboral tubercle in a few zooids (Figure 16.2), otherwise flat, and leaving a central circular lacuna slightly larger than intercostal lacunae, up to $10 \mu \mathrm{m}$ in diameter, rarely visible in frontal view. Orifice transversely D-shaped with straight proximal margin, smooth to slightly crenulated in some zooids, constantly bearing five oral spine bases in non-ovicellate zooids and four in ovicellate zooids; spines stout, robust, $20 \mu \mathrm{m}$ in diameter at the base, tapering towards the tips (10 $\mu \mathrm{m}$ minimum diameter). Avicularia interzooidal, infrequent, placed on an irregularly polygonal cystid of smooth gymnocyst often overgrown by neighbouring autozooids (Figures 16.3, 17.3-6); rostrum ogival, directed distally or distolaterally, lying on the depression between autozooids, smooth; two faint condyles as pivots. Ovicells prominent, helmetshaped, slightly wider than long, smooth, with a median suture and faint radiating costae, in some zooids more visible than in others (Figures 16.2-3, $17.1-2,5)$. Intramural buds present in both autozooids and avicularia (Figure 17.3, 5-6). Ancestrula tatiform, oval, 160-200 $\mu \mathrm{m}$ long by 100-130 $\mu \mathrm{m}$ 

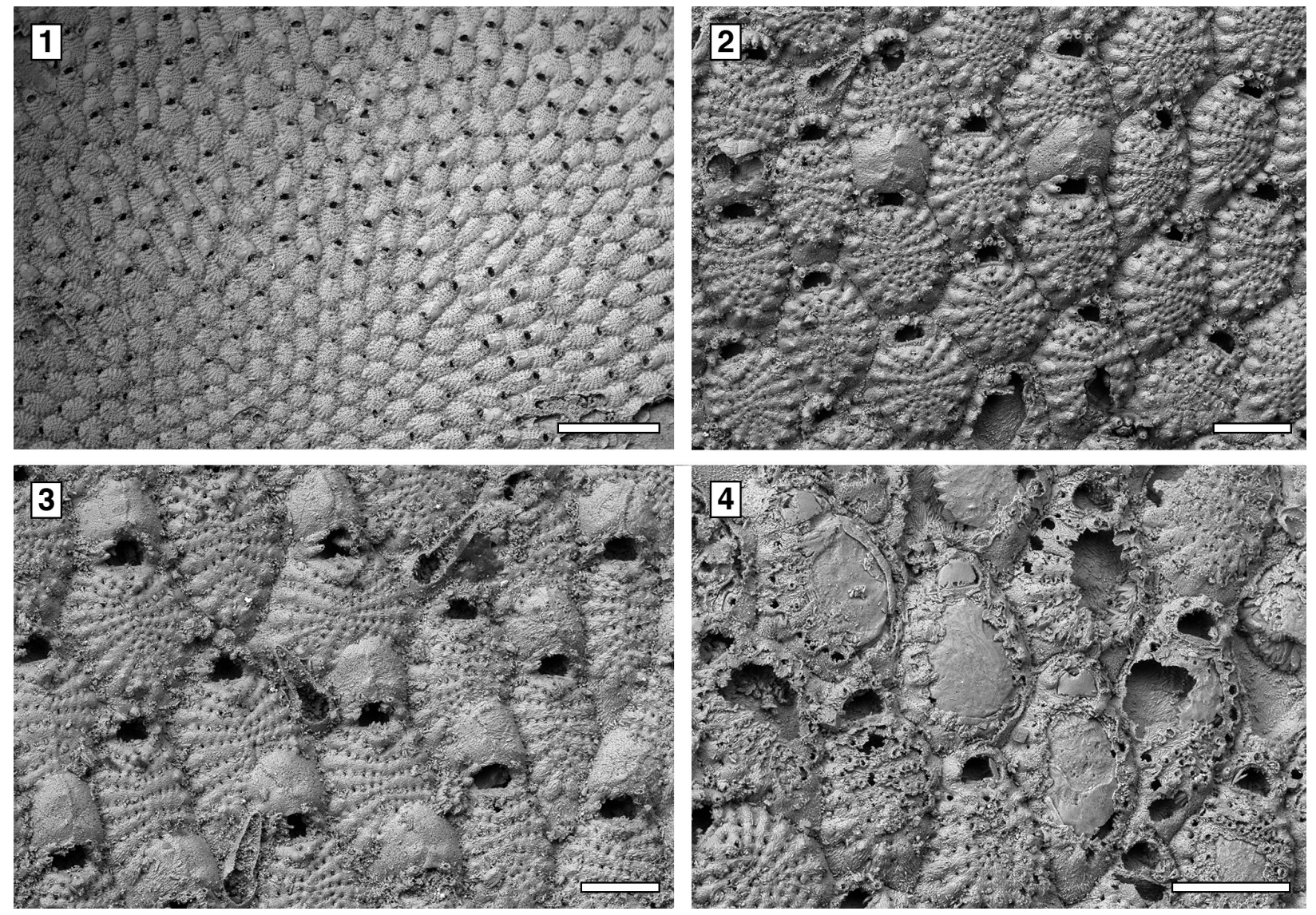

FIGURE 16. Puellina scripta (Reuss, 1848), UF 305776 (Shell 10), Pliocene, lower Tamiami Formation Units 10/11. 1, general view of part of an extensive, sheet-like colony (1 $\mathrm{mm}) . \mathbf{2 - 3}$, groups of ovicellate and non-ovicellate zooids and interzooidal avicularia $(200 \mu \mathrm{m}) .4$, autozooids with peculiar preservation and closure plates with opercular scars $(200 \mu \mathrm{m})$.

wide, surrounded by six autozooids (Figure 18.12); gymnocyst more extensive proximally, tapering laterally, negligible distally; opesia elliptical to oval, occupying most of the frontal surface, $100-130 \mu \mathrm{m}$ long by $95-110 \mu \mathrm{m}$ wide, surrounded by an uncertain number of spines, at least nine. One distal and two distolateral zooids budded directly from the ancestrula, similar to later autozooids but smaller, 190-260 $\mu \mathrm{m}$ long by $160-195 \mu \mathrm{m}$ wide, and with fewer costae forming the frontal shield (up to 10). Costulate kenozooid seen only once as a regeneration of the ancestrula (Figure 18.3-4). Closure plates with opercular scars observed (Figure 16.4). Measurements $(\mu \mathrm{m})$. ZL 421 $\pm 56,329-542(3,25)$; ZW 295 $\pm 39,214-364$ (3, 25); OL 65 $\pm 7,52-75$ (3, 20); OW 88 $\pm 10,75-108$ (3, 20); AvL 222 $\pm 49,132-$ 303 (3, 12); AvW 118 $\pm 14,96-140(3,12)$; OvL $175 \pm 15,151-203(3,25)$; OvW 196 $\pm 18,157-232$ $(3,25)$.

Remarks. Puellina scripta was first described from the Miocene (Badenian) of Austria and subsequently reported worldwide. However, with the advent of the SEM, several new species have been distinguished within those records originally attributed to $P$. scripta. Compared to the holotype images depicted by Bishop and Househam (1987, p. 58, figures 98-99), the Tamiami Formation species is similar in the size and shape of zooids and avicularia, in having the suboral mucro poorly developed or totally absent, the frontal shield almost flat with costae separated by four intercostal lacunae, and five robust oral spines. The main difference is the number of costae forming the frontal shield, which is usually 16 in the holotype while is commonly 13 in the Florida specimens, although this still falls in the range of variation of the Florida species. The Tamiami Formation species is also similar to Puellina radiata forma scripta (Reuss, 1848) sensu Canu and Bassler (1923, p. 89, pl. 35, fig. 1) reported from the Pliocene of Virginia. Among recent western Atlantic species, those characterized by five oral spines in non-ovicellate zooids differ from the Tamiami Formation species in the following characters: Puellina saginata Win- 

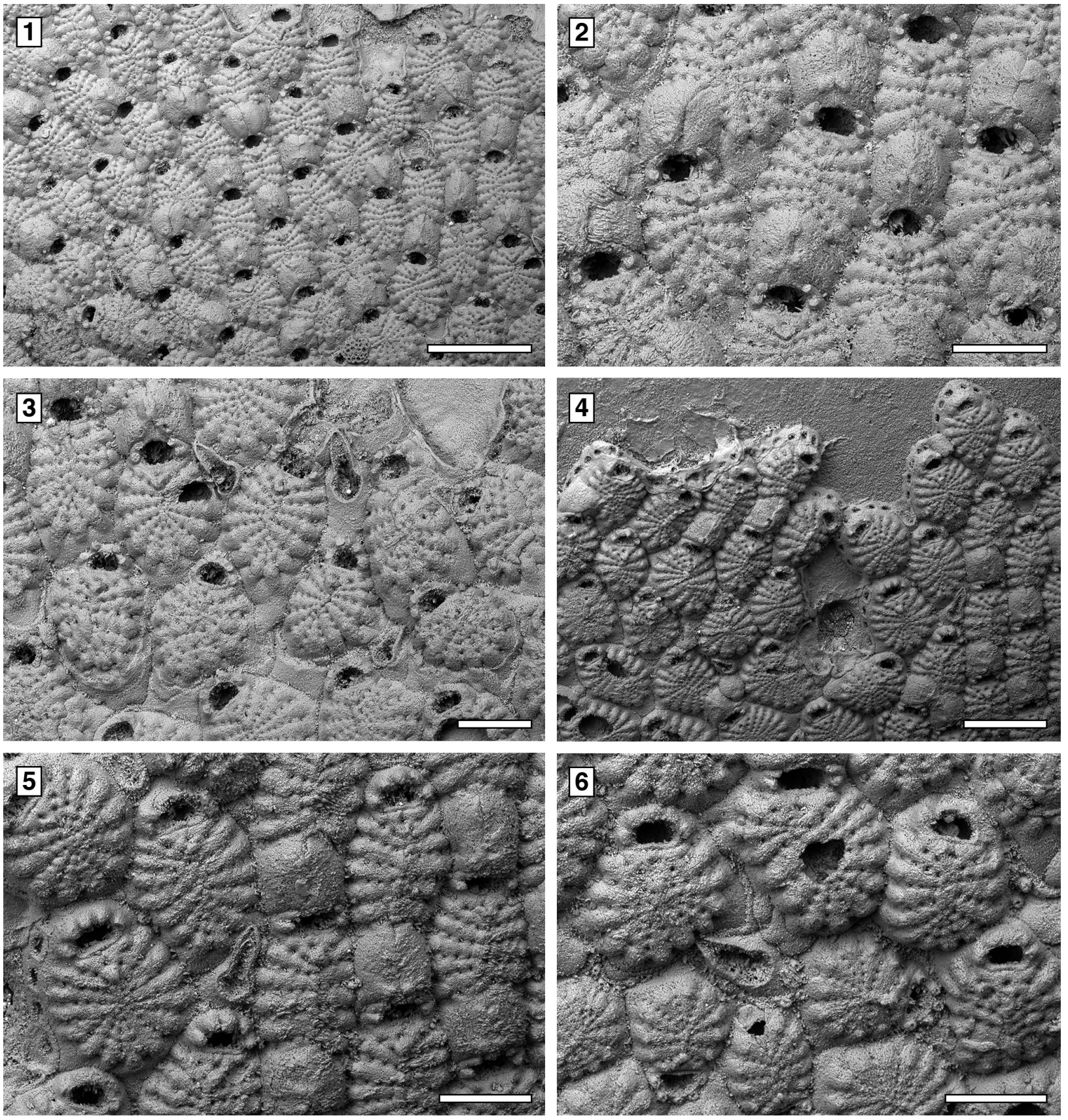

FIGURE 17. Puellina scripta (Reuss, 1848), UF 305777 (Shell 343), Pliocene, lower Tamiami Formation Units $10 / 11$. 1 , general view of part of an extensive, sheet-like colony $(500 \mu \mathrm{m}) .2$, groups of ovicellate zooids showing a median suture and faint radiating costae $(200 \mu \mathrm{m})$. 3, autozooids with more extensive, smooth gymnocyst proximally, reparative buds and interzooidal avicularia $(200 \mu \mathrm{m}) .4$, autozooids at colony growth edge showing pore-chamber windows $(400 \mu \mathrm{m}) .5$, close-up of ovicellate and non-ovicellate zooids showing the robust oral spines and interzooidal avicularium with intramural bud $(200 \mu \mathrm{m}) . \mathbf{6}$, group of autozooids and interzooidal avicularium intramurally budded (200 $\mu \mathrm{m})$. 

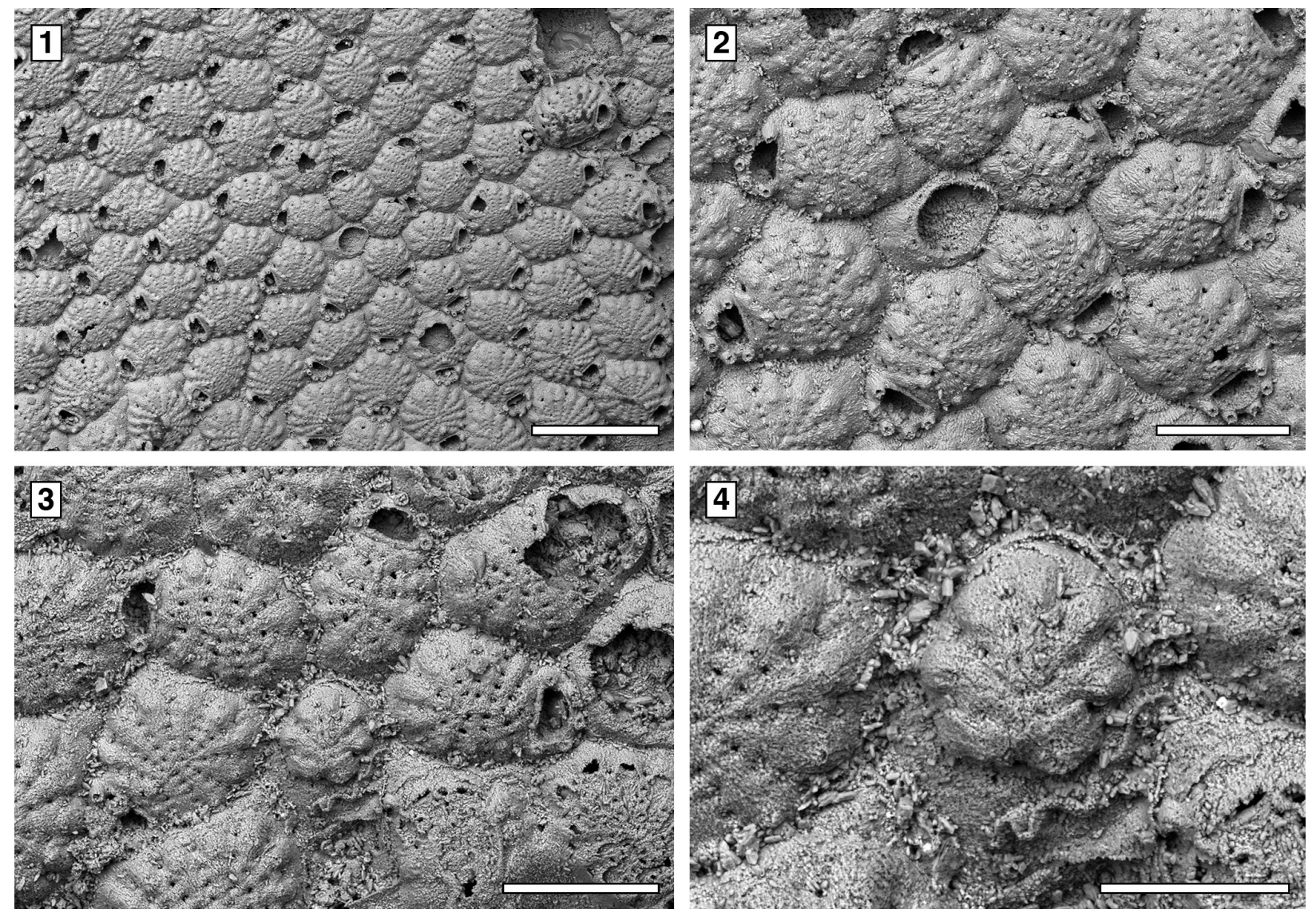

FIGURE 18. Puellina scripta (Reuss, 1848), Pliocene, lower Tamiami Formation Units 10/11. 1-2, UF 305778 (Shell 22). 1, tatiform ancestrula and early astogeny $(500 \mu \mathrm{m})$. 2, close-up of the tatiform ancestrula and periancestrular zooids $(200 \mu \mathrm{m}) .3-4$, UF 305779 (Shell 3). 3, costulate kenozooid as regeneration of the ancestrula and first budded autozooids $(200 \mu \mathrm{m}) .4$, close-up of the costulate kenozooid regenerated from the tatiform ancestrula $(100 \mu \mathrm{m})$.

ston, 2005 has a more extensive gymnocyst surrounding the margins of the zooids and a greater number of intercostal lacunae; $P$. testudinea Winston, 2005 has long pointed avicularia $(270 \mu \mathrm{m}$ long) and outer edges of costae raised into a tubercle; P. capronensis Winston, 2005 has smaller zooids (including orifice and ovicells), a large suboral pore, lacks avicularia and usually encrusts very small substrates such as sand or gravel grains; P. minervae Winston, 2016 has two large lacunae adjacent to the $\mathrm{V}$-shaped first pair of costae.

A peculiar type of dissolution/abrasion has been observed in some specimens of $P$. scripta from the Tamiami Formation (Figure 13.4). Its origin is unknown.

Genus Spiniflabellum Di Martino and Rosso, 2015 Spiniflabellum laurae sp. nov. Figure 19

zoobank.org/D90E131A-92DB-4DF0-9228-3AA17C6716AC
Type material. Holotype UF 305780 (Shell 30); paratype UF 305781 (Shell 135; not figured). Pliocene, lower Tamiami Formation.

Etymology. Named after Dr. Laura J. Cotton (University of Bristol) who helped to collect the specimens.

Diagnosis. Colony encrusting; autozooids elliptical. Frontal shield formed by $12-13$ costae separated by four intercostal pores. One to three prominent pelmatidia on each costa. Distalmost pair of costae bifid and converging across the orifice. Primary orifice somewhat trapezoidal. Two platy elements, terminating in two coalescent oral spines located distolaterally, converging towards the zooid midline and touching distally. Pore-chamber windows visible at colony edges.

Description. Colony encrusting, multiserial, unilaminar (Figure 19.1). Pore-chamber windows visible along zooidal margins at colony growing edge, oval, small, 20-25 $\mu \mathrm{m}$ long (Figure 19.1). Autozooids distinct with deep interzooidal furrows, ellipti- 

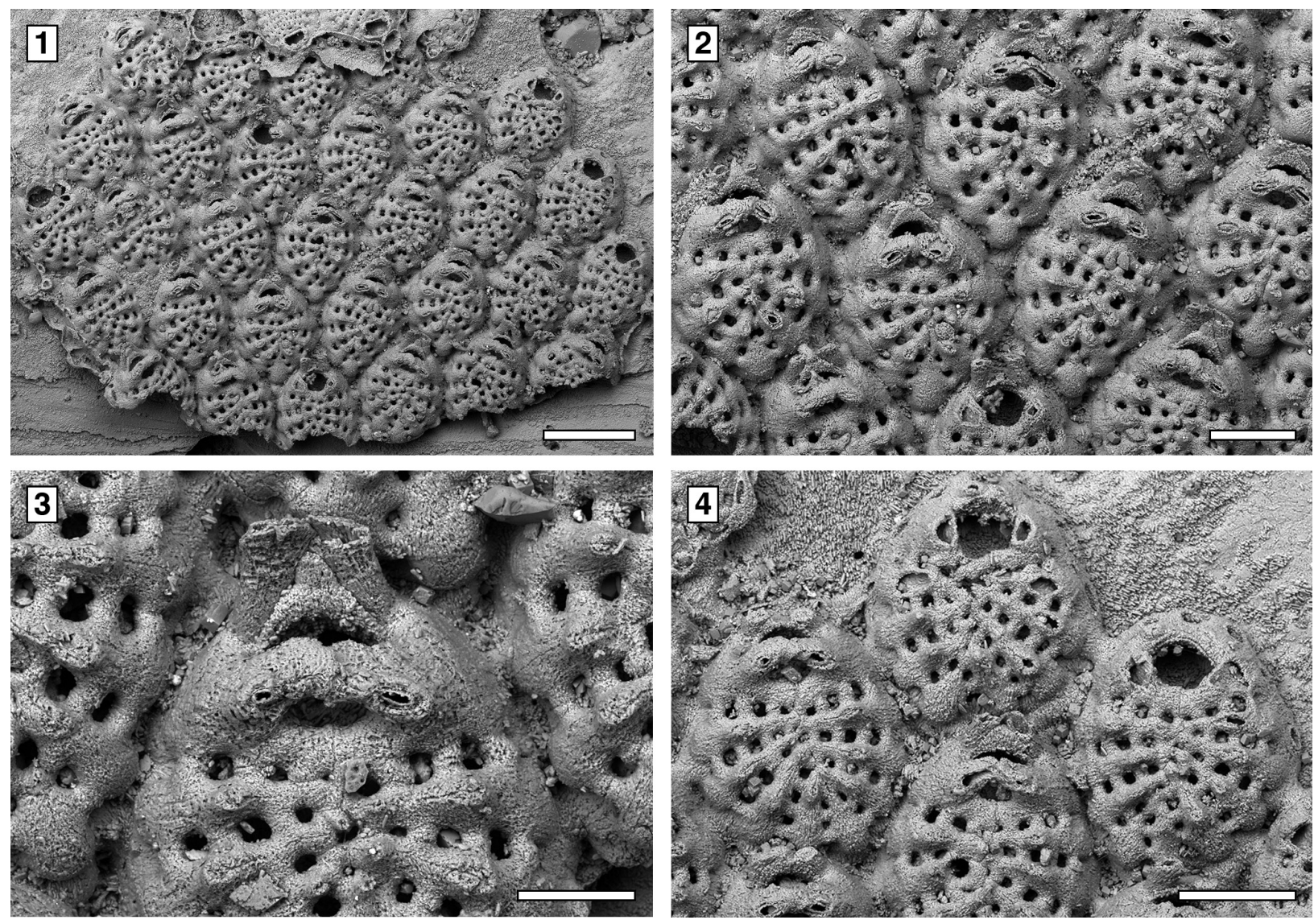

FIGURE 19. Spiniflabellum laurae sp. nov., holotype UF 305780 (Shell 30), Pliocene, lower Tamiami Formation Units 10/11. 1, general view of the small colony $(400 \mu \mathrm{m})$. 2, group of autozooids $(200 \mu \mathrm{m})$. 3, close-up of the orifice overarched by the distalmost pair of costae forming an eight-shaped pseudospiramen and bearing distally two platy elements terminating in two coalescent spines $(100 \mu \mathrm{m}) . \mathbf{4}$, autozooids at colony growing edge showing pore-chamber windows and orifice $(200 \mu \mathrm{m})$.

cal, longer than wide (mean L/W 1.32), quincuncially arranged. Frontal shield convex, formed by 12-13 narrow costae $(20-30 \mu \mathrm{m})$, each separated by four oval to subcircular intercostal pores, 5-10 $\mu \mathrm{m}$ in diameter (Figure 19.2). Costae converging and fused at zooidal midline; $1-3$ prominent tubular pelmatidia on each costa but usually broken off. Distalmost pair of costae smooth, bifid, the anterior bifurcation converging across the orifice, forming a wide arch and figure-eight-shaped to elliptical, proximomedian pseudospiramen (Figure 19.3), obscuring the primary orifice in frontal view; the arch bears two hollow pelmatidia. Primary orifice trapezoidal, about $45 \mu \mathrm{m}$ long by 60 $\mu \mathrm{m}$ wide, with rounded distal margin and straight or slightly convex proximal margin (Figure 19.4). Two platy elements each terminating in two coalescent, hollow spines placed distolaterally to the orifice, converging and touching distally along zooidal midline (Figure 19.3). Avicularia, kenozooids and ovicells not observed. Ancestrula not seen.
Measurements ( $\mu \mathrm{m})$. ZL 274 $\pm 19,252-300(1,10)$; ZW 208 $\pm 15,190-230(1,10)$.

Remarks. Spiniflabellum laurae sp. nov. is the second fossil species of this genus to be described. An early Miocene species, S. jacksoni Di Martino, Taylor, and Portell, 2017, was described from the Chipola Formation in Florida. Spiniflabellum laurae sp. nov. differs from $S$. jacksoni in the number of costae forming the frontal shield (12-13 costae in the former species, 16-21 in the latter species), in the number of pelmatidia per costa (variably 1-3 in $S$. laurae sp. nov. and constantly single and central in S. jacksoni), and in the position of the coalescent spines, which are placed distolateral to the orifice, converging towards the zooidal midline and touching in the Pliocene species, but are always completely separated in the Miocene species. The recent Spiniflabellum spinosum (Canu and Bassler, 1928a), reported from Cuba and the Strait of Florida, differs from the new species in having 16-18 costae forming the frontal shield and a larger, char- 
acteristically bat-shaped pseudospiramen. All species of Spiniflabellum are rare, with a single or a few colonies found, and all lack ovicells. However, more material needs to be found to confirm that the absence of ovicells is not a sampling artifact.

Superfamily Hippothooidea Busk, 1859

Family Trypostegidae Gordon, Tilbrook and Winston in Winston, 2005

Genus Trypostega Levinsen, 1909

Trypostega composita sp. nov.

Figure 20

zoobank.org/B4CFD4C4-1A4F-4887-B720-9E6A54249424

Type material. Holotype UF 305782 (Shell 21); paratypes UF 305783 (Shell 261) and UF 305784 (Shell 17). Pliocene, lower Tamiami Formation.

Etymology. From the Latin 'compositus, -a, -um', meaning 'compound' and referring to the characteristic small subcolonies produced by frontal eruptive budding.

Diagnosis. Colony encrusting, sheet-like with frontal subcolonies. Basal pore-chambers present. Autozooid frontal shield gymnocystal, smooth, evenly pseudoporous. Orifice dimorphic, cleithridiate; suboral umbo absent. Ovicell kenozooidal, globular, evenly pseudoporous. Zooeciules highly variable in size and shape, often distal or inbetween autozooids, isolated or forming clusters.

Description. Colony encrusting, multiserial, uni- to multilaminar, sheet-like with several, small, circular subcolonies produced by frontal eruptive budding (Figure 20.1, 4). Basal pore-chamber windows visible in autozooids at colony growth edge, circular to transversely elliptical, variable in size, 20-35 $\mu \mathrm{m}$ long by $10-20 \mu \mathrm{m}$ wide, evenly spaced (Figure $20.1,6)$. Autozooids arranged quincuncially, distinct, with shallow interzooidal furrows, elongate (mean L/W 1.64), rounded rhomboidal or irregularly polygonal. Frontal shield slightly convex or flat, smooth, evenly perforated by $50-60$ circular pseudopores, 5-10 $\mu \mathrm{m}$ in diameter; pseudopores distal to the orifice aligned in an arch. Orifice dimorphic, keyhole-shaped (cleithridiate), slightly longer than wide (mean L/W 1.22), with a horseshoe-shaped anter separated by medially directed condyles from a U-shaped sinus, narrow and extended for one-quarter of total orifice length in non-ovicellate autozooids (Figure 20.3), but broader and shallower in ovicellate zooids (Figure 20.4); suboral umbo absent. Ovicell kenozooidal, globular, longer than wide, evenly perforated as the frontal shield of zooids, the associated zooeciule distinguished by its circular opening in the distal centre about $20 \mu \mathrm{m}$ in diameter (Figure 20.5-7). Zooeciules often distal to an autozooid or laterally between two autozooids, isolated or in clusters, variable in size and shape, with the frontal shield evenly pseudoporous and a larger, rounded, sinuate opening, 10-20 $\mu \mathrm{m}$ in diameter (Figure 20.2, $6-8)$. Closure plates often occur (Figure 20.8).

Measurements $(\mu \mathrm{m})$. ZL 438 $\pm 40,376-510(3,20)$;

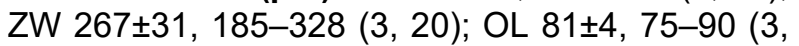
20); OW 66 $\pm 3,62-72(3,20)$; OvL 266 $\pm 29,224-$ 310 (2, 18); OvW 226 $17,196-254$ (2, 18); ZcL $179 \pm 60,100-340$ (3, 20); ZcW 137 $\pm 54,68-272$ (3, 20).

Remarks. Canu and Bassler (1923) referred to specimens of Trypostega found in Neogene formations of North America as the widespread extant Trypostega venusta (Norman, 1903), which is now known to be limited to the northeast Atlantic Ocean, from southern Britain to Madeira and into the Mediterranean Sea (Tilbrook, 2006). Trypostega venusta differs from $T$. composita sp. nov. in having a well-developed, suboral umbo constantly present in each autozooid. Among Eocene North American species, T. elongata Canu and Bassler, 1920 differs in having carinated ovicells; $T$. inornata (Gabb and Horn, 1862) differs in having an imperforate frontal shield; and $T$. undulata Canu and Bassler, 1920 differs in having very distinct transverse undulations. The early Miocene $T$. vokesi Di Martino, Taylor, and Portell, 2017 from the Chipola Formation of Florida has fewer, larger pseudopores. Among recent Atlantic species, $T$. ilhabelae Winston and Vieira, 2013 differs in having a large, suboral umbo; $T$. striatula (Smitt, 1873) has marked longitudinal striations; and T. tropicalis Winston, Vieira and Woollacott, 2014 has a broader sinus.

Superfamily Adeonoidea Busk, 1884

Family Adeonidae Busk, 1884

Genus Reptadeonella Busk, 1884

Reptadeonella umbilicata (Lonsdale, 1845) comb. nov.

Figure 21

1845 Cellepora umbilicata Lonsdale, p. 507.

1923 Adeona heckeli Canu and Bassler, p. 158, pl. 24, figures 1, 2.

Figured material. UF 305785 (Shell 101); UF 305786 (Shell 18); UF 305787 (Shell 19). Pliocene, lower Tamiami Formation.

Description. Colony encrusting, multiserial, uni- or multi-laminar, sheet-like (Figure 21.1, 4). Autozooids delimited by slightly raised lateral margins, zooidal boundaries becoming unclear in later ontogeny owing to secondary calcification spreading from marginal areolar pores (Figure 21.6), arranged in alternating rows in unilaminar colonies, 

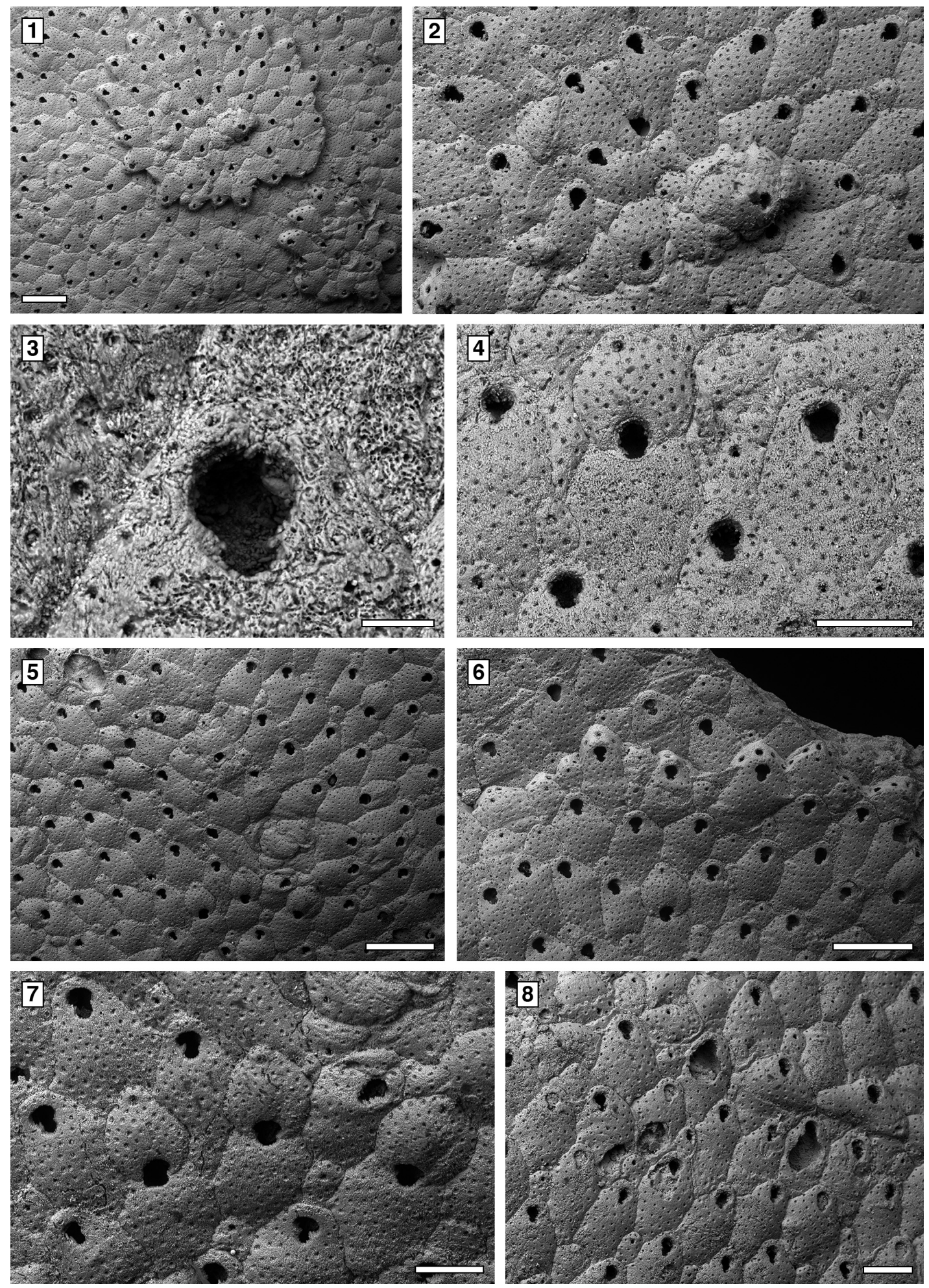

FIGURE 20. Trypostega composita sp. nov., Pliocene, lower Tamiami Formation Units 10/11. 1-2, holotype UF 305782 (Shell 21). 1, view of part of the colony with two subcolonies produced by frontal budding (500 $\mu \mathrm{m})$. 2, group of

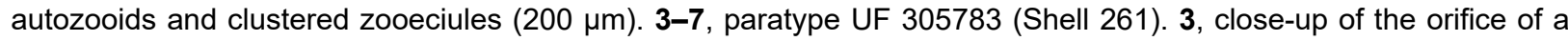
non-ovicellate autozooid $(40 \mu \mathrm{m}) .4$, group of ovicellate and non-ovicellate zooids showing the dimorphic orifices (200 $\mu \mathrm{m}) .5$, group of ovicellate and non-ovicellate zooids and zooeciules (500 $\mu \mathrm{m}) .6$, growing edge of a subcolony showing pore-chamber windows and zooeciules in clusters $(400 \mu \mathrm{m}) .7$, group of ovicellate and non-ovicellate zooids (200 $\mu \mathrm{m})$. 8, paratype UF 305784 (Shell 17), autozooids, some with closure plates $(200 \mu \mathrm{m})$. 

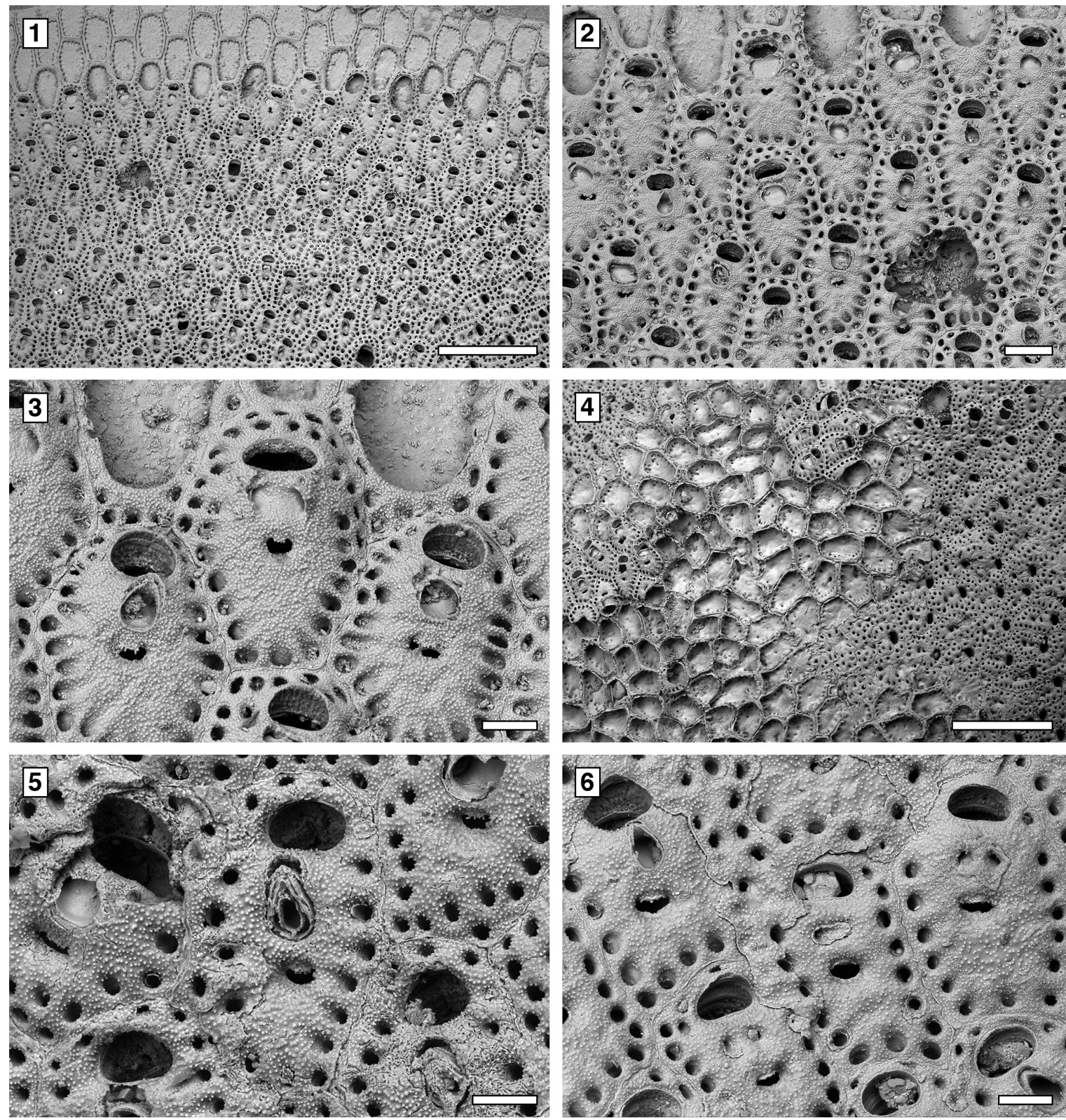

FIGURE 21. Reptadeonella umbilicata (Lonsdale, 1845) comb. nov., Pliocene, lower Tamiami Formation Units 10/11. 1-3, UF 305785 (Shell 101). 1, view of part of an extensive, unilaminar colony including the growing edge (1 mm). 2, group of autozooids with or without the suboral avicularium and a fertile zooid in the centre $(200 \mu \mathrm{m})$. 3, close-up of the fertile zooid $(100 \mu \mathrm{m}) . \mathbf{4 - 5}$, UF 305786 (Shell 18). 4, view of part of a multilaminar colony (1 mm). 5, close-up of an autozooid with intramural buds in the suboral avicularium $(100 \mu \mathrm{m})$. 6, UF 305787 (Shell 19), group of autozooids mostly lacking a suboral avicularium and calcification spreading from marginal areolar pores $(100 \mu \mathrm{m})$.

irregularly in subsequent layers in multilaminar colonies, rounded polygonal, elongate (mean L/W 1.53). Frontal shield flat to slightly convex, finely granular, with a single (rarely double) row of circular, marginal areolar pores, $20-30 \mu \mathrm{m}$ in diameter.
Primary orifice transversely elliptical, sunken; secondary orifice transversely elliptical to beanshaped, the margin bordered by a thin rim of smooth calcification; peristome not prominent at level with zooid surface. Suboral avicularium pres- 

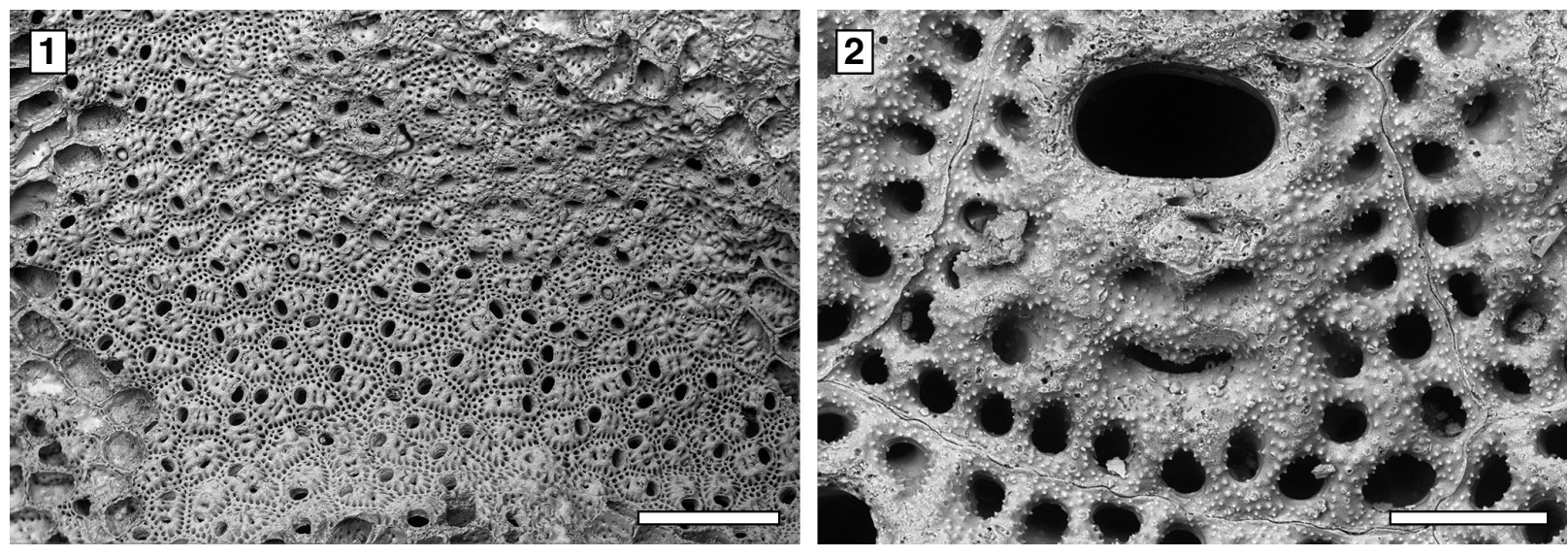

FIGURE 22. Reptadeonella umbilicata (Lonsdale, 1845) comb. nov., holotype NHMUK D53195, Pliocene, Petersburg, Virginia, USA. 1, general view of the colony $(1 \mathrm{~mm}) .2$, close-up of an autozooid lacking the suboral avicularium $(100 \mu \mathrm{m})$.

ent or absent, drop-shaped, median, perpendicular or oblique on frontal shield, sloping proximally; rostrum pointed triangular, raised, directed distally or distolaterally, sometimes indenting the proximal margin of the secondary orifice; mandible hinged on two small condyles. If absent, in place of the avicularium one or two areolar pores are seen. No other avicularia. Spiramen crescent-shaped, placed 35-45 $\mu \mathrm{m}$ below the avicularium, about 60 $\mu \mathrm{m}$ wide by $15-20 \mu \mathrm{m}$ long, distal margin with projecting denticles, usually set at level of zooid surface, seldom in a circular depression. Intramural buds common in suboral avicularia (Figure 21.5). Gonozooids similar to ordinary autozooids but with a transverse secondary orifice placed more proximally and overarched by a double row of marginal areolar pores distally; avicularium absent (Figure 21.2-3, 6). Ancestrula not seen.

Measurements $(\mu \mathrm{m})$. ZL 468 $\pm 41,421-537(2,15)$; ZW 305 $\pm 37,252-360$ (2, 15); OL 82 $\pm 7,69-91$ (2,

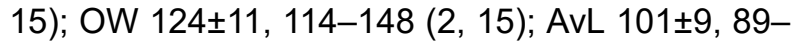
126 (2, 15); AvW 66 $\pm 10,55-87(2,15)$.

Remarks. With its multilayered encrusting colonies, this species fits better in the genus Reptadeonella Busk, 1884 than Adeona Lamouroux, 1812, which forms large, erect, cribrate colonies. Lonsdale (1845) described $R$. umbilicata from the Pliocene of Petersburg in Virginia. Although the holotype (D53195; Figure 22.1-2) lacks avicularia, all other characters resemble the Pliocene species from Florida. In both the Virginia (Figure 22.2) and Florida (Figure 21.3) colonies, among the zooids lacking avicularia only those with transverse orifices and a distal double row of marginal areolar pores are interpreted as gonozooids.
Superfamily Lepralielloidea Vigneaux, 1949

Family Lepraliellidae Vigneaux, 1949

Genus Celleporaria Lamouroux, 1821 Celleporaria sp.

Figure 23

Figured material. UF 305788 (Shell 31); UF 305789 (Shell 11); UF 305790 (Shell 107). Pliocene, lower Tamiami Formation.

Description. Colony encrusting, multiserial, mounded multilaminar (Figure 23.1, 4). Autozooids distinct, with deep interzooidal furrows, rectangular along the growing edge of the colony but erect and chaotically arranged in the central area of the colony, longer than wide (mean L/W 1.35). Frontal shield convex and smooth, imperforate apart from a few, small, circular marginal areolar pores scattered along the lateral zooidal margins, 20-30 $\mu \mathrm{m}$ in diameter. Orifice transversely $\mathrm{D}$-shaped with concave proximal margin; two distolateral oral spine bases, 15-30 $\mu \mathrm{m}$ in diameter (Figure 23.2). Adventitious avicularium suboral, placed horizontally and parallel to one side of the proximal margin of the orifice, elliptical, laterally, and outwards directed; rostrum serrated and raised, crossbar complete. Interzooidal avicularia large, elliptical to spatulate, placed on a swollen cystid and irregularly scattered within the colony, randomly directed (Figure 23.2-4); rostrum rounded and raised, crossbar complete. Ovicells hood-shaped, widely open, imperforate, smooth, about $150 \mu \mathrm{m}$ long by $320 \mu \mathrm{m}$ wide (Figure 23.5).

Measurements $(\mu \mathrm{m})$. ZL 546 $\pm 46,466-600(2,10)$;

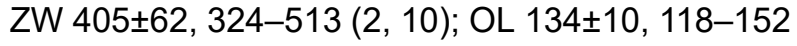
$(2,10)$; OW 167 $\pm 8,155-177$ (2, 10); AvL (suboral)

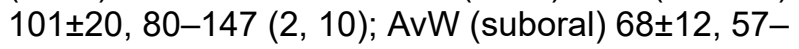



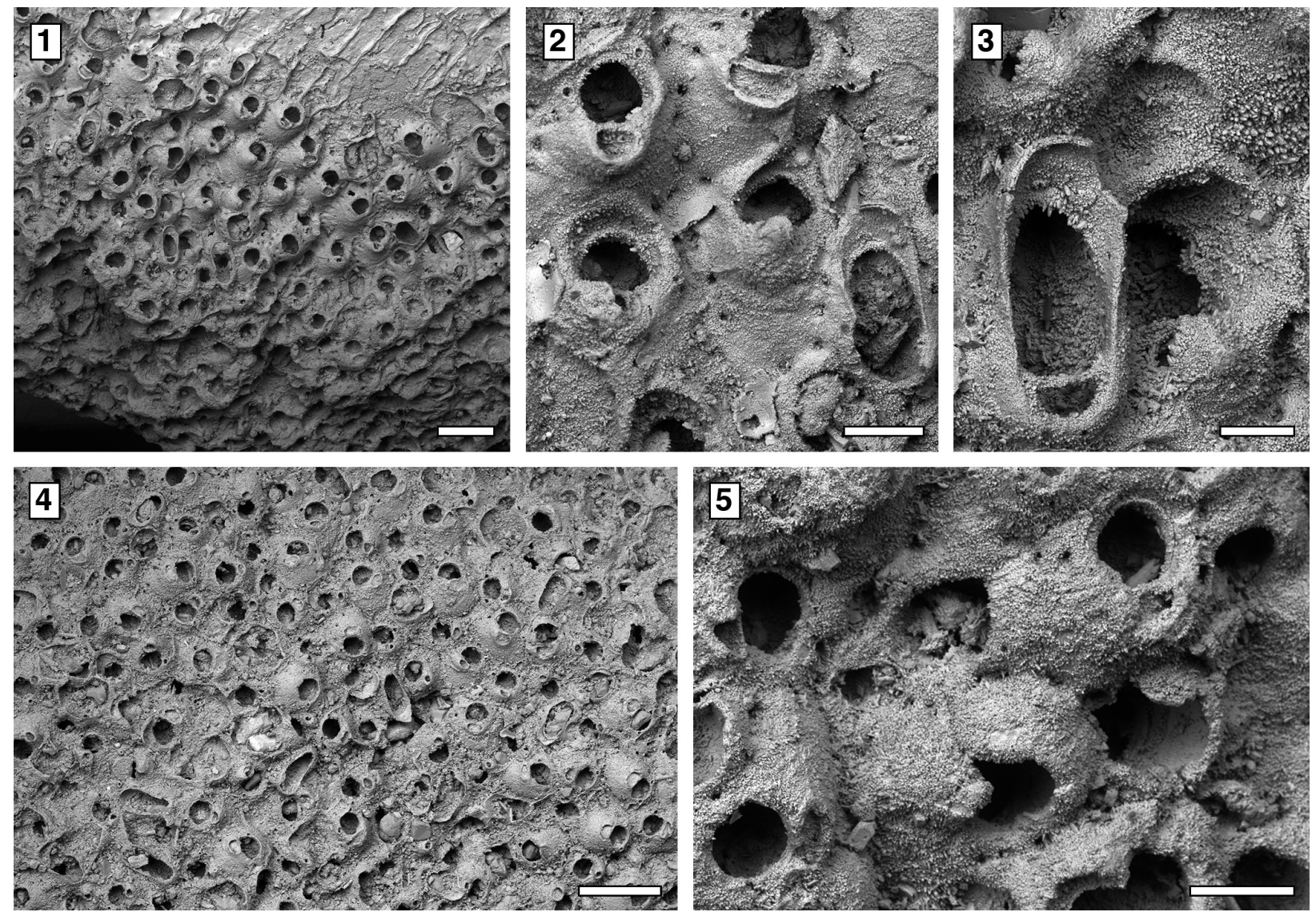

FIGURE 23. Celleporaria sp., Pliocene, lower Tamiami Formation Units 10/11. 1-3, UF 305788 (Shell 31). 1, general view of a multilaminar, mounded colony $(600 \mu \mathrm{m})$. 2, close-up of autozooids with two, distolateral, oral spine bases and suboral avicularia $(200 \mu \mathrm{m}) .3$, close-up of an interzooidal avicularium (100 $\mu \mathrm{m})$. 4, UF 305789 (Shell 11), general view of a mounded colony with several interzooidal avicularia $(500 \mu \mathrm{m}) .5$, ovicellate zooids $(200 \mu \mathrm{m})$.

96 (2, 10); AvL (interzooidal) 426 $\pm 29,381-460(2$, $10)$; AvW (interzooidal) 251 $\pm 22,222-286(2,10)$.

Remarks. Celleporaria cf. bicornis (Canu and Bassler, 1923) from the lower Miocene Chipola Formation of Florida (Di Martino et al., 2017) is similar in having two distolateral oral spine bases, a suboral avicularium with serrated rostrum, and large interzooidal avicularia with an elliptical to spatulate rostrum; it differs in having nodular frontal shields and ovicells, and an orifice with the proximal margin bearing three pointed denticles. Celleporaria magnifica (Osburn, 1914) has a similar orifice, but lacks oral spine bases, the interzooidal avicularia have duck-beak shaped rostra and sometimes a median triangular ligula, and zooidal length reaches $1 \mathrm{~mm}$. The shape of the orifice is also similar in C. albirostris (Smitt, 1873). However, C. albirostris differs in having granular frontal shield and a prickly appearance produced by the sharply pointed avicularian rostra (Winston, 2005).
Family Bryocryptellidae Vigneaux, 1949

Genus Cyclocolposa Canu and Bassler, 1923

Cyclocolposa perforata Canu and Bassler, 1923

Figure 24

1923 Cyclocolposa perforata Canu and Bassler, $p$. 135, pl. 30, figures 6-14.

Figured material. UF 305791 (Shell 36); UF 305792 (Shell 10). Pliocene, lower Tamiami Formation.

Description. Colony encrusting, multiserial, unilaminar, sheet-like (Figure 24.1). Pore-chamber windows present (Figure 24.5). Autozooids distinct, with shallow furrows, arranged quincuncially, pentagonal to hexagonal, longer than wide (mean L/W 1.38). Frontal shield convex, coarsely granular, imperforate apart from one or two rows of circular marginal areolar pores, $15-25 \mu \mathrm{m}$ in diameter. Orifice subcircular, slightly wider than long (mean L/W 0.93 ), surrounded by a shortly raised, funnelshaped peristome. An uncertain number (possibly four) of disto-oral spine bases present in early bud- 

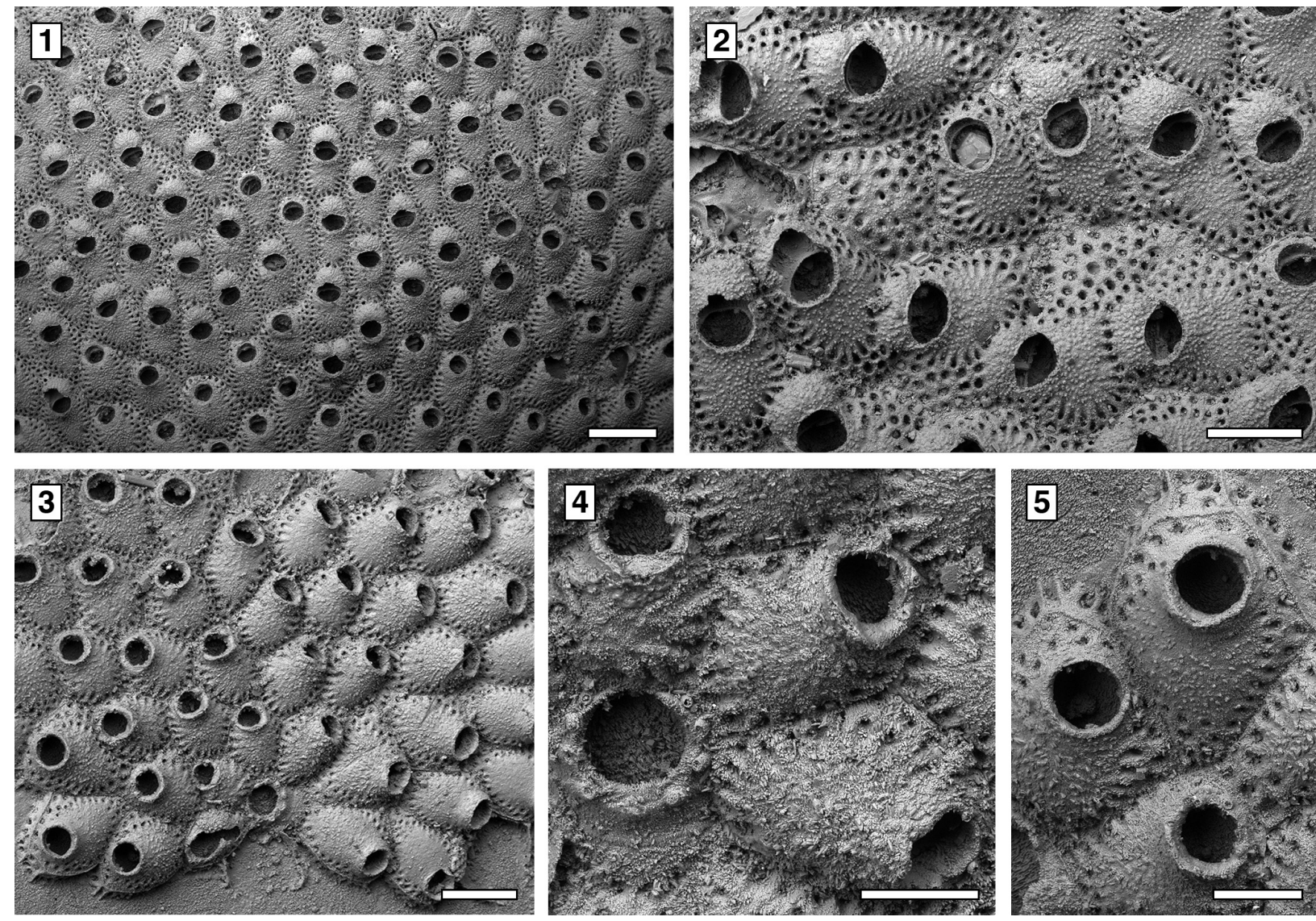

FIGURE 24. Cyclocolposa perforata Canu and Bassler, 1923, Pliocene, lower Tamiami Formation Units 10/11. 1-2, UF 305791 (Shell 36). 1, view of part of an extensive colony with most of the zooids ovicellate (500 $\mu \mathrm{m})$. 2, group of ovicellate and non-ovicellate zooids and kenozooids (400 $\mu \mathrm{m})$. 3-5, UF 305792 (Shell 10). 3, tatiform ancestrula and early astogeny $(400 \mu \mathrm{m}) .4$, close-up of the tatiform ancestrula and first budded autozooids (200 $\mu \mathrm{m})$. 5, close-up of autozooids at the colony growing edge showing pore chamber windows $(200 \mu \mathrm{m})$.

ded autozooids up to the third generation, and randomly in later autozooids. Ovicells prominent, globular, slightly wider than long, imperforate and granular like the frontal shield (Figure 24.1-2). Avicularia absent. Kenozooids occasionally form at contacts between two colonies or fusing lobes of the same colony, irregularly shaped, with granular frontal shield lacking an opening but with up to three rows of areolar pores (Figure 24.2). Ancestrula tatiform, $320 \mu \mathrm{m}$ long by $280 \mu \mathrm{m}$ wide, surrounded by seven autozooids, a single zooid budded distally ( $330 \mu \mathrm{m}$ long by $285 \mu \mathrm{m}$ wide), and two zooids distolaterally (405-412 $\mu \mathrm{m}$ long by 280-320 $\mu \mathrm{m}$ wide), smaller than later autozooids; gymnocyst extensive proximally, occupying about one-third of the frontal surface; opesia transversely elliptical, $145 \mu \mathrm{m}$ long by $155 \mu \mathrm{m}$ wide, encircled by 12 oral spine bases (Figure 24.3-4).

Measurements $(\mu \mathrm{m})$. ZL 552 $\pm 54,462-638(2,20)$; ZW 394 $\pm 50,300-456$ (2, 20); OL 168 $\pm 13,150-$
192 (2, 14); OW 180 $\pm 17,144-215$ (2, 14); OvL

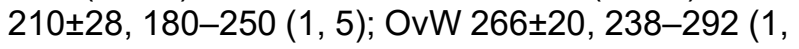
$5)$.

Remarks. Echols (1960) provided the unique report of Cyclocolposa perforata Canu and Bassler, 1923 from the Tamiami Formation, the species being reported previously only from the lower Pleistocene Waccamaw Formation of South Carolina. The genus name Cyclocolposa was first used by Canu and Bassler (1920, p. 431) and the type species - C. perforata (USNM 68617; Figure 25.13) - was mentioned, but not described, making both Cyclocolposa Canu and Bassler, 1920 and $C$. perforata Canu and Bassler, 1920 nomina nuda. The genus and species were validly published by Canu and Bassler (1923). Cyclocolposa tenuiparietis Canu and Bassler, 1923 (Figure 25.4-6; USNM 68618), from the Duplin Marl (now assigned to the upper Pliocene Jackson Bluff Formation) of Florida, differs from Cyclocolposa perforata in hav- 

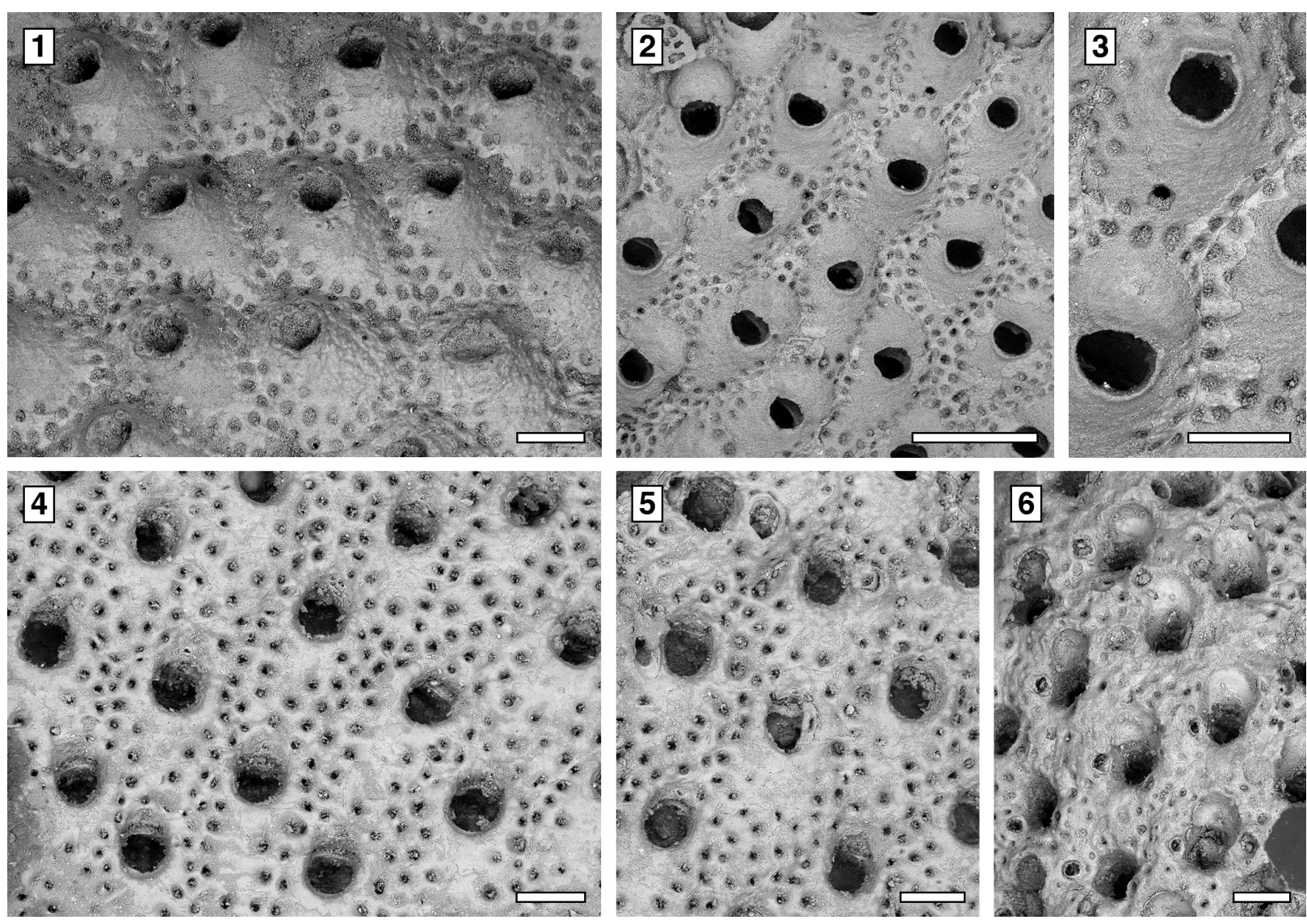

FIGURE 25. 1-3, Cyclocolposa perforata Canu and Bassler, 1923, syntype USNM 68617, early Pleistocene, South Carolina, USA. 1, group of autozooids $(200 \mu \mathrm{m})$. 2, group of ovicellate zooids $(500 \mu \mathrm{m})$. 3, close-up of an ovicellate and a non-ovicellate zooid $(200 \mu \mathrm{m})$. 4-6, Cyclocolposa tenuiparietis Canu and Bassler, 1923, syntype USNM 68618 , Pliocene, Florida, USA. 4, group of autozooids $(200 \mu \mathrm{m})$. 5, group of autozooids, one with a latero-oral avicularium $(200 \mu \mathrm{m}) . \mathbf{6}$, group of zooids with incomplete ovicells $(200 \mu \mathrm{m})$.

ing larger marginal areolar pores migrating towards the centre of the frontal shield and occasionally a round, latero-oral avicularium.

Family Romancheinidae Jullien, 1888

Genus Hippopleurifera Canu and Bassler, 1925

Hippopleurifera mucronata (Smitt, 1873)

Figure 26

1873 Hippothoa mucronata Smitt, p. 45, pl. 8, figure 169.

2005 Hippopleurifera mucronata Winston, p. 54, figures 143-145.

2017 Hippopleurifera mucronata Di Martino et al., p. 151, figure 41.

Figured material. UF 305793 (Shell 29). Pliocene, lower Tamiami Formation.

Description. Colony encrusting, multiserial, unilaminar, sheet-like (Figure 26.1). Pore-chamber windows present (Figure 26.2). Autozooids distinct, with shallow interzooidal furrows, rhomboidal to hexagonal, longer than wide (mean L/W 1.34).
Frontal shield convex, finely granular, with an imperforate central area, a row of marginal areolar pores and one or two less complete inner rows of pores, giving a faintly ribbed appearance. Marginal areolar pores subcircular, 20-30 $\mu \mathrm{m}$ in diameter. Orifice with two rounded condyles, dividing a semielliptical anter from a U-shaped sinus. Collar surrounding the orifice rises proximally in a pointed suboral umbo, often levelled-off, and bears 5-7 stout, closely spaced oral spine bases, 35-40 $\mu \mathrm{m}$ in diameter; only four spines visible in ovicellate zooids. Avicularia occasionally present, adventitious, placed laterally on the frontal shield at about mid-length (Figure 26.2, 4); rostrum rounded triangular, slightly curved, proximolaterally directed; no crossbar or condyles. Ovicells globose, slightly broader than long, with teardrop-shaped, marginal areolar pores, $40-50 \mu \mathrm{m}$ long, between ribs of calcification radiating outward from a prominent, central tubercle (Figure 26.3-4). 

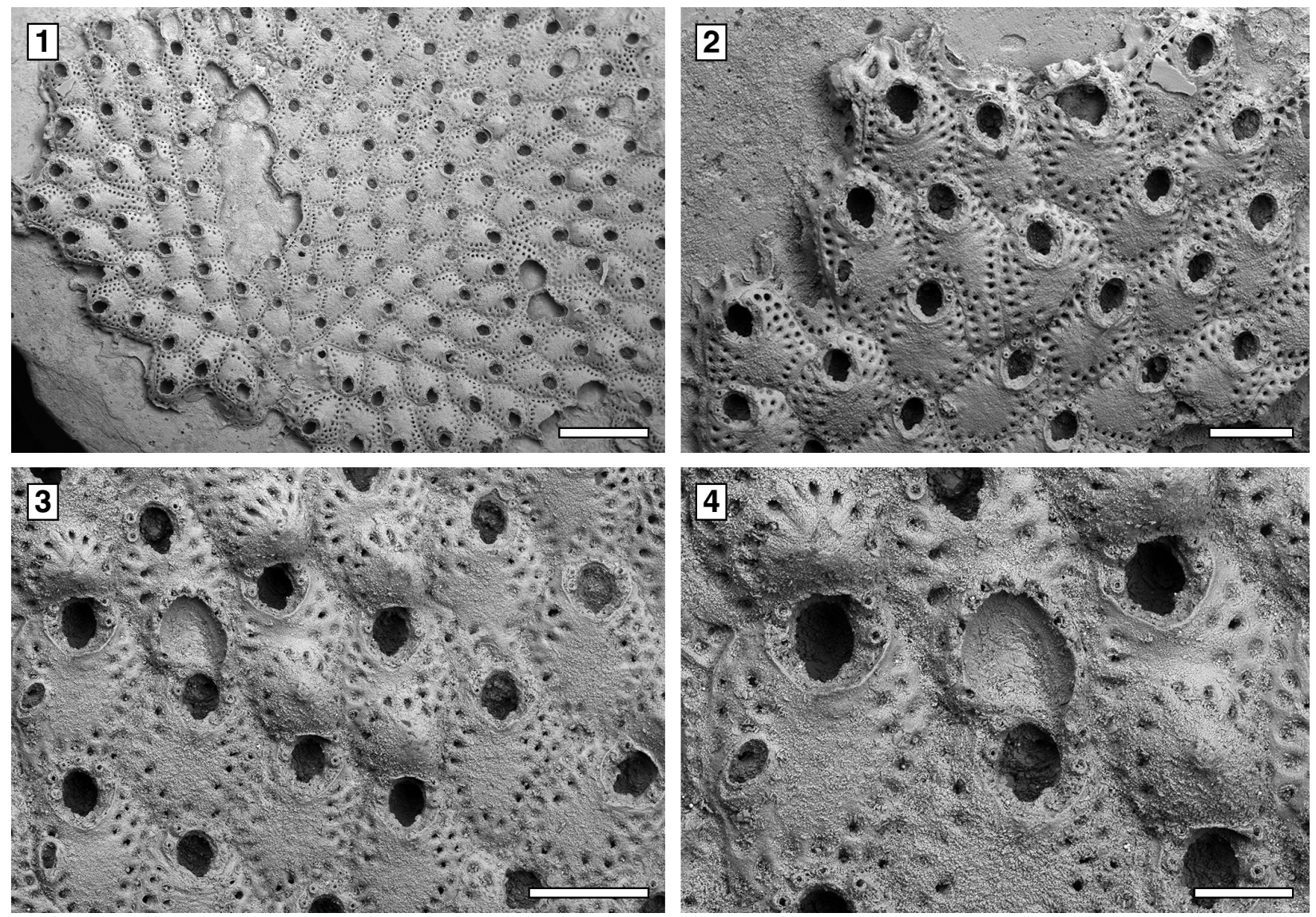

FIGURE 26. Hippopleurifera mucronata (Smitt, 1873), UF 305793 (Shell 29). Pliocene, lower Tamiami Formation Units 10/11. 1, general view of the colony $(1 \mathrm{~mm}) . \mathbf{2}$, group of autozooids at colony growing edge showing pore-chamber windows $(400 \mu \mathrm{m}) .3$, group of ovicellate zooids $(400 \mu \mathrm{m}) .4$, close-up of ovicellate zooids, one with an adventitious avicularium $(200 \mu \mathrm{m})$.

Measurements $(\mu \mathrm{m})$. ZL 630 $\pm 84,510-862(1,20)$;

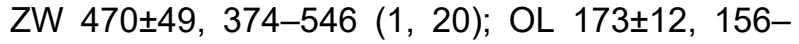
200 (1, 10); OW 131 $\pm 8,116-142(1,10) ;$ OvL

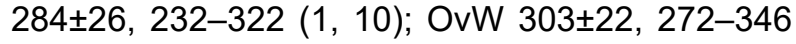

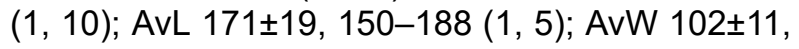
90-118 $(1,5)$.

Remarks. In addition to the Pliocene Tamiami Formation, the fossil record of Hippopleurifera mucronata includes the lower Miocene Chipola Formation of Florida (Di Martino et al., 2017) and the Pliocene Duplin Formation of North Carolina (Canu and Bassler, 1923). Although based only on a few zooids, the early Miocene specimen shows generally smaller measurements than the Tamiami Formation specimens. This difference might be related to temperature, the Chipola Formation representing a more tropical climate. At the present day, $H$. mucronata is a common inhabitant of the shelf off the southeast coast of the USA, Gulf of California, and the Caribbean (Winston, 2005).
Family Sfeniellidae Gordon, 2006

Genus Stephanollina Vigneaux, 1949

Stephanollina vorax (Canu and Bassler, 1923)

Figure 27

1923 Gemelliporella vorax Canu and Bassler, p. 111, pl. 19, figures 1-9.

2006 "Gemelliporella" vorax Gordon, pl. 2, figures 3, 4.

2017 Stephanollina vorax Di Martino and Taylor, p. 788.

Figured material. UF 305794 (Shell 34); UF 305795 (Shell 35); UF 305796 (Shell 22). Pliocene, lower Tamiami Formation.

Description. Colony encrusting, multiserial, unilaminar (Figure 27.1). Pore-chamber windows visible at colony growing edge, circular to transversely elliptical, variable in size, $30-70 \mu \mathrm{m}$ long by $15-35$ $\mu \mathrm{m}$ wide (Figure 27.1). Autozooids quincuncially arranged, rounded hexagonal, slightly longer than wide (mean L/W 1.15), distinct with shallow interzooidal furrows; zooidal boundaries becoming ill- 

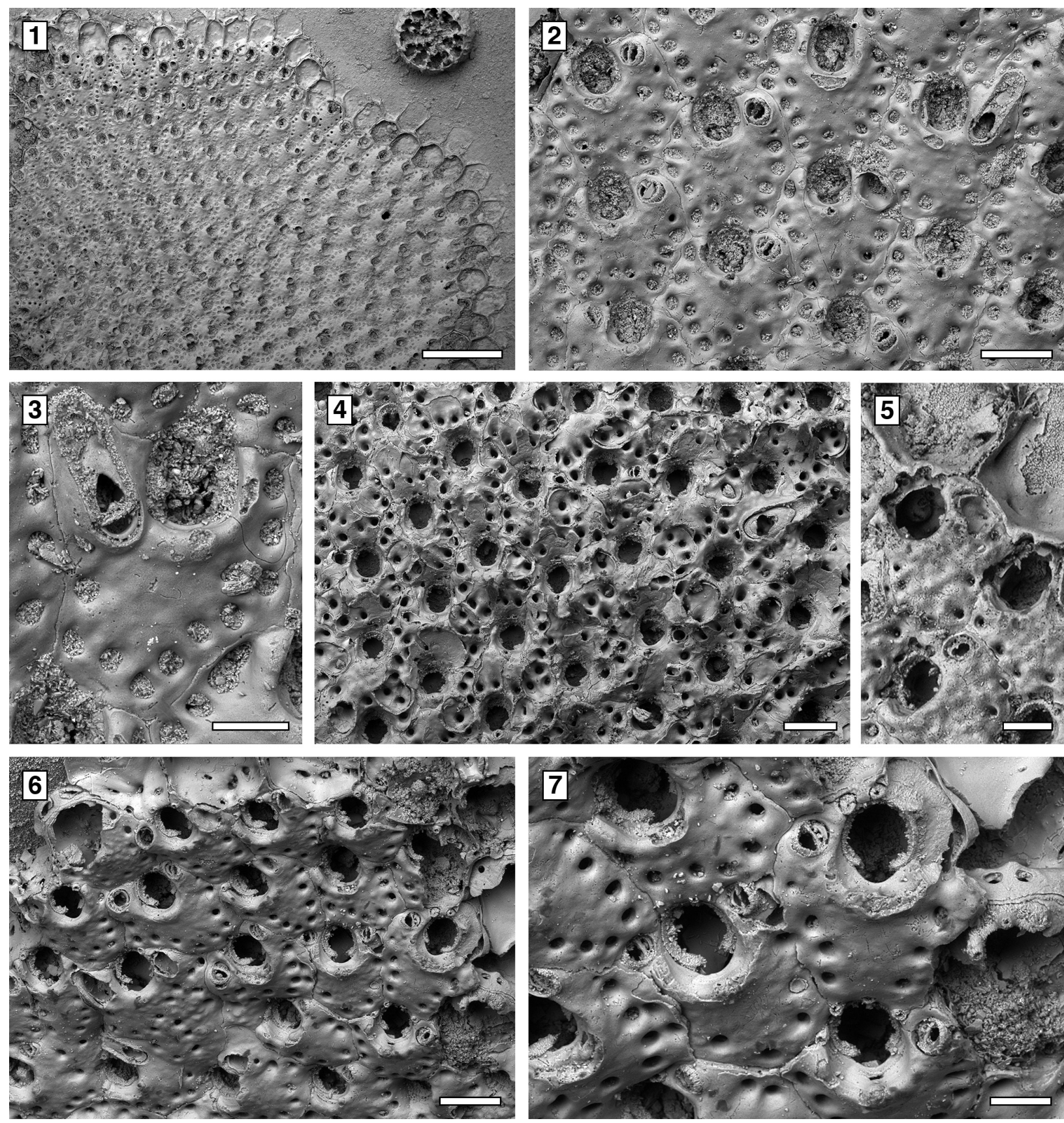

FIGURE 27. Stephanollina vorax (Canu and Bassler, 1923), Pliocene, lower Tamiami Formation Units 10/11. 1-3, UF 305794 (Shell 34). 1, general view of the colony $(1 \mathrm{~mm})$. 2, group of autozooids with different types of adventitious avicularia $(200 \mu \mathrm{m}) .3$, close-up of an autozooid with a fusiform avicularium (100 $\mu \mathrm{m}) .4-5$, UF 305795 (Shell 35). 4, general view of an 'old' part of a colony $(200 \mu \mathrm{m}) . \mathbf{5}$, close-up of two autozooids showing the cormidial secondary orifice $(100 \mu \mathrm{m}) .6-7$, UF 305796 (Shell 22 ). 6 , group of autozooids at colony growing edge showing pore-chamber windows $(200 \mu \mathrm{m}) .7$, close-up of two autozooids $(100 \mu \mathrm{m})$.

defined through ontogeny because of secondary calcification spreading from marginal areolar pores. Frontal shield slightly convex or flat, nodular, imperforate apart from a row of circular to dropshaped marginal areolar pores, $15-50 \mu \mathrm{m}$ long, along the proximal and lateral zooidal margins. Pri- mary orifice longer than wide, keyhole shaped, with two robust, pointed condyles proximally placed and downwardly and proximomedially directed, separating an arched anter from a shallow, slightly narrower sinus with a concave proximal margin. Secondary orifice cormidial, formed by the frontal 

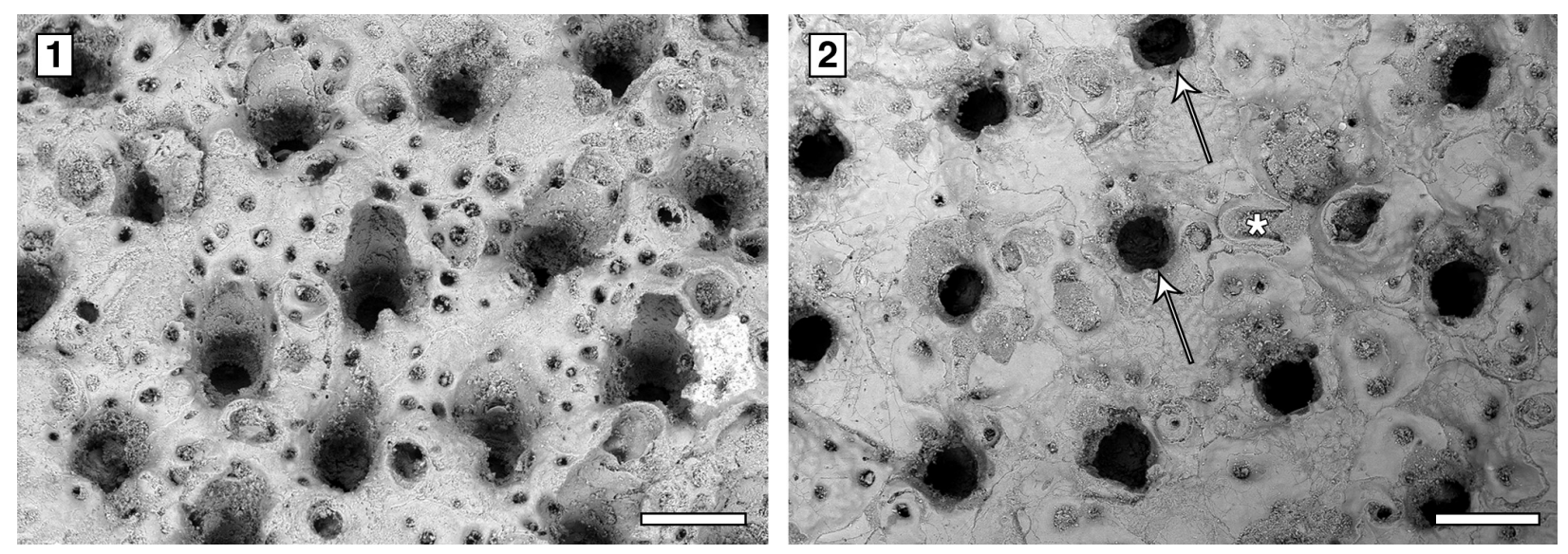

FIGURE 28. Stephanollina vorax (Canu and Bassler, 1923), syntypes. 1, USNM 651310, Pleistocene, South Carolina, USA, group of autozooids $(200 \mu \mathrm{m})$. 2, USNM 651312, Pliocene, North Carolina, USA, group of autozooids with arrows indicating orifices in which condyles are preserved and asterisk indicating a fusiform avicularium partially covered by secondary calcification $(200 \mu \mathrm{m})$.

shields of the surrounding distal zooids, forming a crenulated margin of lobes and cusps, the latter in the position of the oral spine bases (Figure 27.46). A small, pointed, suboral mucro develops with ontogeny (Figure 27.4). Commonly three oral spine bases, exceptionally four, about $20 \mu \mathrm{m}$ in diameter. Adventitious avicularia budded from marginal areolar pores, distolateral to the orifice, single or paired, of two types; most commonly small, rounded to oval, placed on a swollen cystid sloping distally, directed laterally outwards or proximolaterally, with complete pivotal bar (type 1; Figure 27.2, 6); rarely large, fusiform to slightly spatulate, with arrowhead shaped opening, distally or distolaterally directed, the tip of the rostrum resting on the frontal shield of the next distal zooid, with complete pivotal bar (type 2; Figure 27.3-5). Avicularia lacking in some autozooids. Ovicells and ancestrula not observed.

Measurements $(\boldsymbol{\mu m})$. ZL 393 $\pm 48,326-515(2,20)$; ZW 341 $\pm 30,286-404$ (2, 20); OL 134 $\pm 9,120-146$ $(2,10)$; OW 118 $\pm 5,111-123$ (2, 10); AvL (type 1) 71 $\pm 9,60-85$ (3, 10); AvW (type 1) 64 $\pm 9,54-80$ (3, 10); AvL (type 2) 223 $\pm 60,158-295(3,5)$; AvW

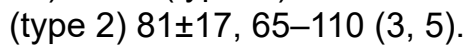

Remarks. Stephanollina vorax has been reported in the early Miocene through to the early Pleistocene of the eastern USA from North Carolina to Florida (Canu and Bassler, 1923). Di Martino and Taylor (2017) re-assigned the specimens of "Gemelliporella" vorax examined by Gordon (2006) to Stephanollina Vigneaux, 1949. These non-type specimens are from the Miocene of Wilmington in North Carolina and housed in the Canu Collection at the Museum Nationale d'Histoire Naturelle, Paris. New SEM images of two syntypes (USNM 651310 separated from USNM 68575, and USNM 651312 separated from USNM 68576) (Figure 28) confirm this attribution. In the Tamiami Formation specimens ancestrulae and ovicells are lacking. Canu and Bassler (1923, p. 111) described the ancestrula as a small autozooid and the ovicell as "convex, little salient, deeply embedded in the distal zooecium". Only incomplete ovicells were observed in the syntypes examined and in the specimens figured by Gordon (2006).

Superfamily Smittinoidea Levinsen, 1909

Family Smittinidae Levinsen, 1909

Genus Smittoidea Osburn, 1952

Smittoidea maleposita (Canu and Bassler, 1923) comb. nov.

Figure 29

1923 Smittina maleposita Canu and Bassler, p. 144, pl. 31, figures 10, 11.

Figured material. UF 305797 (Shell 17); UF 305798 (Shell 258). Pliocene, lower Tamiami Formation.

Description. Colony encrusting, multiserial, multilaminar, sheet-like (Figure 29.1). Autozooids distinct with shallow interzooidal furrows, ill-defined later in ontogeny owing to frontal budding and secondary calcification, irregularly arranged, polygonal, almost as long as wide (mean L/W 1.03). Frontal shield flat to slightly convex, nodular, with one or two series of large conspicuous marginal areolar pores (Figure 29.2-3); areolae circular to elliptical, 40-45 $\mu \mathrm{m}$ long. Orifice slightly longer than wide, with triangular, pointed condyles proxi- 

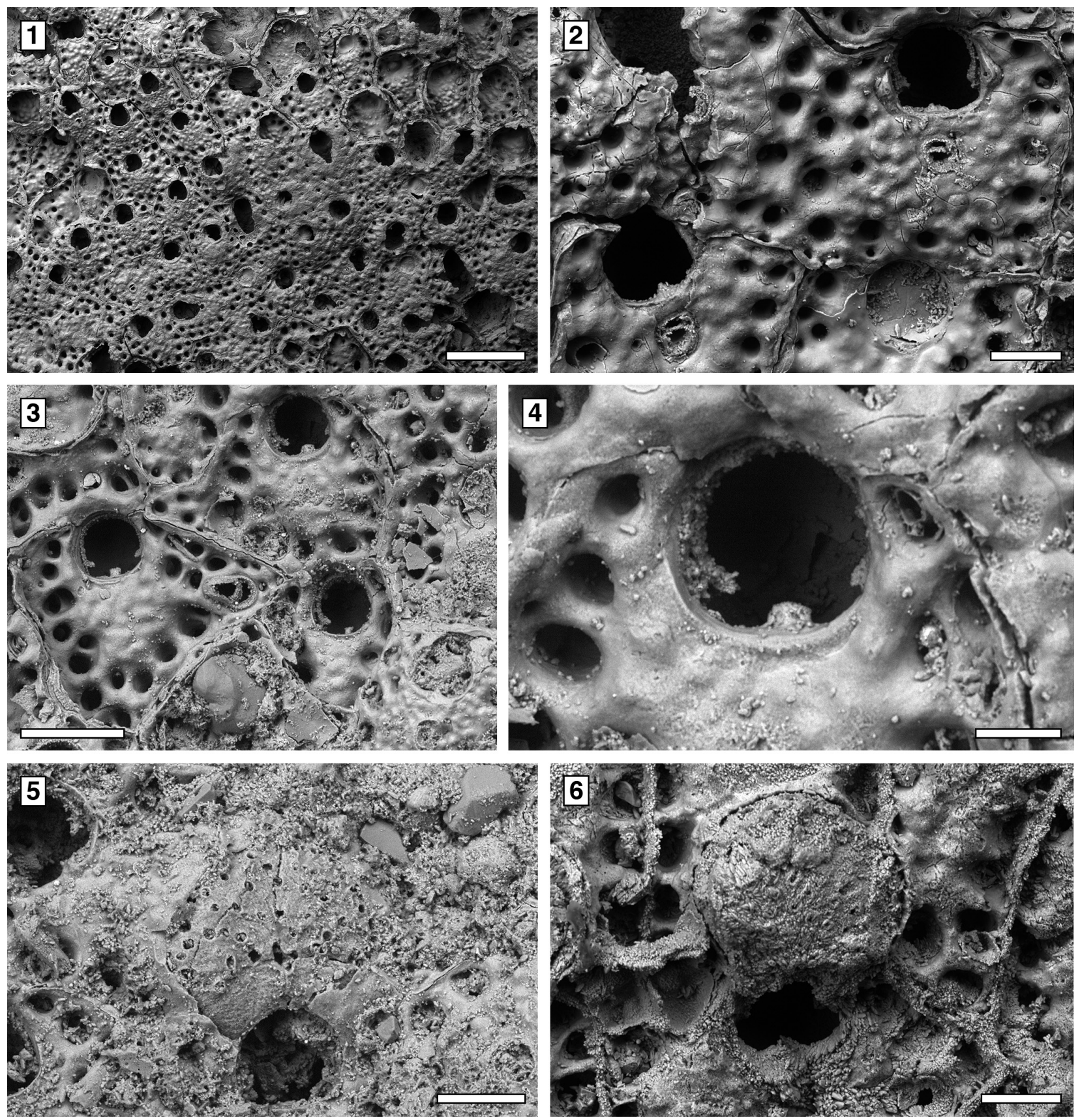

FIGURE 29. Smittoidea maleposita (Canu and Bassler, 1923) comb. nov., Pliocene, lower Tamiami Formation Units 10/11. 1-5, UF 305797 (Shell 17). 1, part of a multilaminar colony (500 $\mu \mathrm{m})$. 2, close-up of two autozooids with median, suboral avicularium and closure plate $(100 \mu \mathrm{m}) .3$, close-up of an autozooid with avicularium at the proximolateral corner $(200 \mu \mathrm{m}) .4$, close-up of the orifice $(50 \mu \mathrm{m}) .5$, close-up of an ovicell $(100 \mu \mathrm{m}) . \mathbf{6}$, UF 305798 (Shell 258$)$, close-up of an ovicell $(100 \mu \mathrm{m})$.

mally directed (c. $15 \mu \mathrm{m}$ wide) and a rectangular lyrula occupying one-fourth of the proximal border (c. $25 \mu \mathrm{m}$ wide) (Figure 29.4). Oral spine bases absent in late ontogenetic zooids. Two types of adventitious avicularia, both with pivotal bar, are occasionally present: (1) common small, oval avicularia placed medially on the frontal shield, proxi- mal to the orifice and directed proximally (Figure 29.2); (2) rare larger, pointed triangular avicularia, placed on the proximolateral zooidal corner and directed distolaterally (Figure 29.3). Ovicell globular, broader than long, $200 \mu \mathrm{m}$ long by $290 \mu \mathrm{m}$ wide; ectooecium calcified with scattered, small, circular pseudopores, $10-15 \mu \mathrm{m}$ in diameter, the 

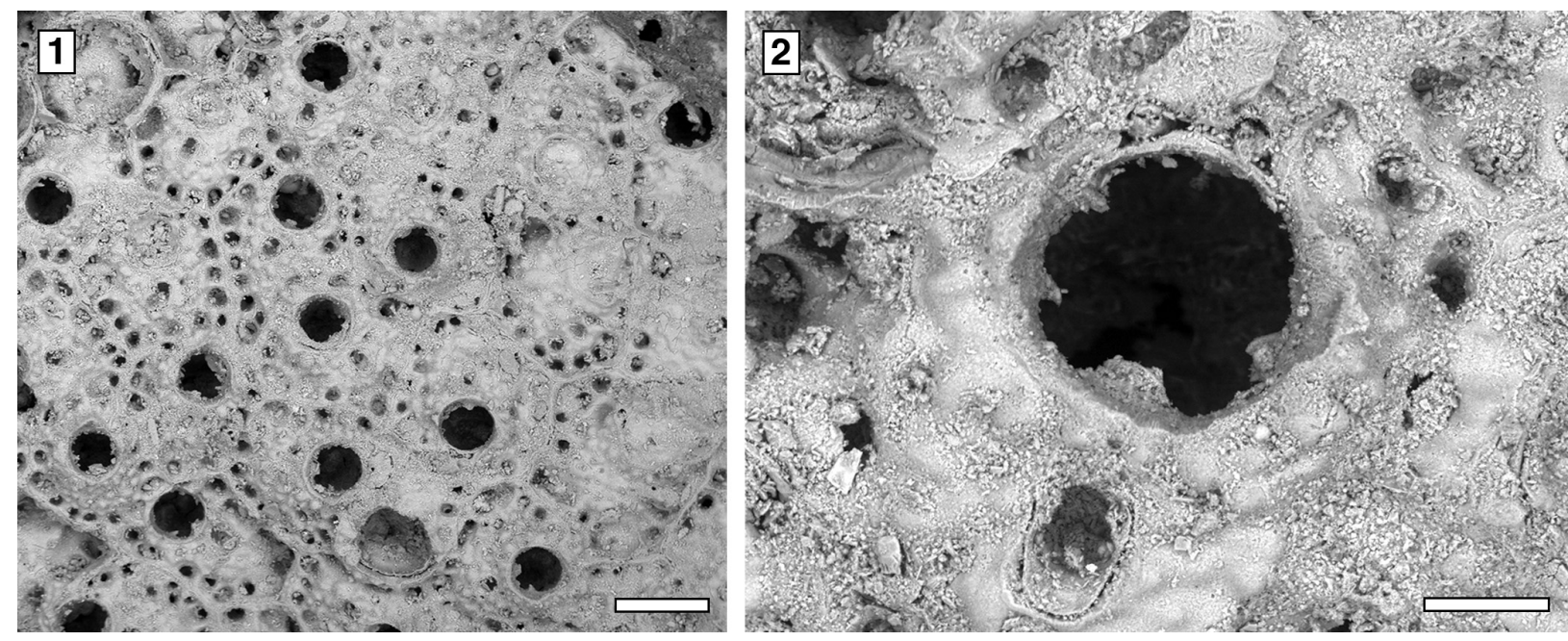

FIGURE 30. Smittoidea maleposita (Canu and Bassler, 1923) comb. nov., syntype, USNM 68641, Pleistocene, Florida, USA. 1, group of autozooids $(200 \mu \mathrm{m}) .2$, close-up of the orifice and suboral avicularium $(50 \mu \mathrm{m})$.

base covered by secondary calcification extending from the frontal shield of the next distal zooid (Figure 29.5-6). Closure plates common (Figure 29.2). Measurements $(\boldsymbol{\mu m})$. ZL 389 $\pm 60,312-502(3,17)$; ZW 376 \pm 59 , 294-487 (3, 17); OL 131 $\pm 5,127-139$ (2, 5); OW 116 $\pm 1,114-117$ (2, 5); AvL (type1)

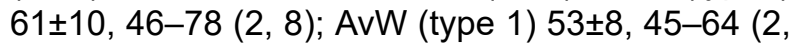
8); AvL (type 2) 100 $\pm 10,93-107$ (2, 2); AvW (type 2) $63 \pm 5,59-66(2,2)$.

Remarks. The original generic attribution of this species seems unlikely because the genus Smittina is characterized by frontal shields that are uniformly pseudoporous. This species fits better in Smittoidea, which has frontal shields centrally imperforate, but with marginal areolar pores, and adventitious avicularia usually situated medially on the frontal, proximal to the orifice. Smittoidea maleposita comb. nov. is known only from the PlioPleistocene of Florida. Canu and Bassler (1923) described this species from the Caloosahatchee Formation at Shell Creek in the DeSoto County (Figure 30).

Family Bitectiporidae MacGillivray, 1895

Genus Metroperiella Canu and Bassler, 1917

Metroperiella reversa (Ulrich and Bassler, 1904) comb. nov.

Figure 31

1904 Lepralia? reversa Ulrich and Bassler, p. 426, pl. 113, figures 1, 2.

1923 Porella reversa Canu and Bassler, p. 148, pl. 23, figures $5-10$.

Figured material. UF 305799 (Shell 343); UF 305800 (Shell 23); UF 305801 (Shell 3); UF
305802 (Shell 461); UF 305803 (Shell 2). Pliocene, lower Tamiami Formation.

Description. Colony encrusting, multiserial, unilaminar, sheet-like (Figure 31.1, 5). Autozooids distinct, with shallow interzooidal grooves, arranged in alternating parallel rows, hexagonal to rectangular, longer than wide (mean L/W 1.74). Pore-chamber windows not seen. Frontal shield slightly convex, nodular, evenly perforated by 30-40 large, funnelshaped pseudopores, 20-30 $\mu \mathrm{m}$ in diameter, each situated at the center of a polygonal mesh. Orifice subcircular (mean L/W 0.98), with two small pointed condyles proximally directed defining a shallowly concave proximal sinus, surrounded by a thick, low peristomial rim (Figure 31.2). Oral spine bases absent. A single, small, adventitious avicularium with pivotal bar constantly present medially on the frontal shield, below the orifice touching the peristomial rim (Figure 31.1); rostrum pointed triangular, proximally directed. Closure plates occurring in both autozooids and avicularia (Figure 31.3). Ovicell globular, broader than long, united with the peristomial rim (Figure 31.3, 5); ectooecium calcified, smooth, with 10-15 large circular pseudopores, 15-35 $\mu \mathrm{m}$ in diameter, the base covered by secondary calcification extending from the frontal shield of the next distal zooid. Irregularly shaped kenozooids lacking an opening present along the edges of juxtaposed colonies or filling gaps in the colony produced by self-overgrowth (Figure 31.45). Ancestrula tatiform, with an uncertain number of circumopesial spines usually overgrown by the six periancestrular autozooids (Figure 31.6); one distal and two distolateral autozooids budded directly 

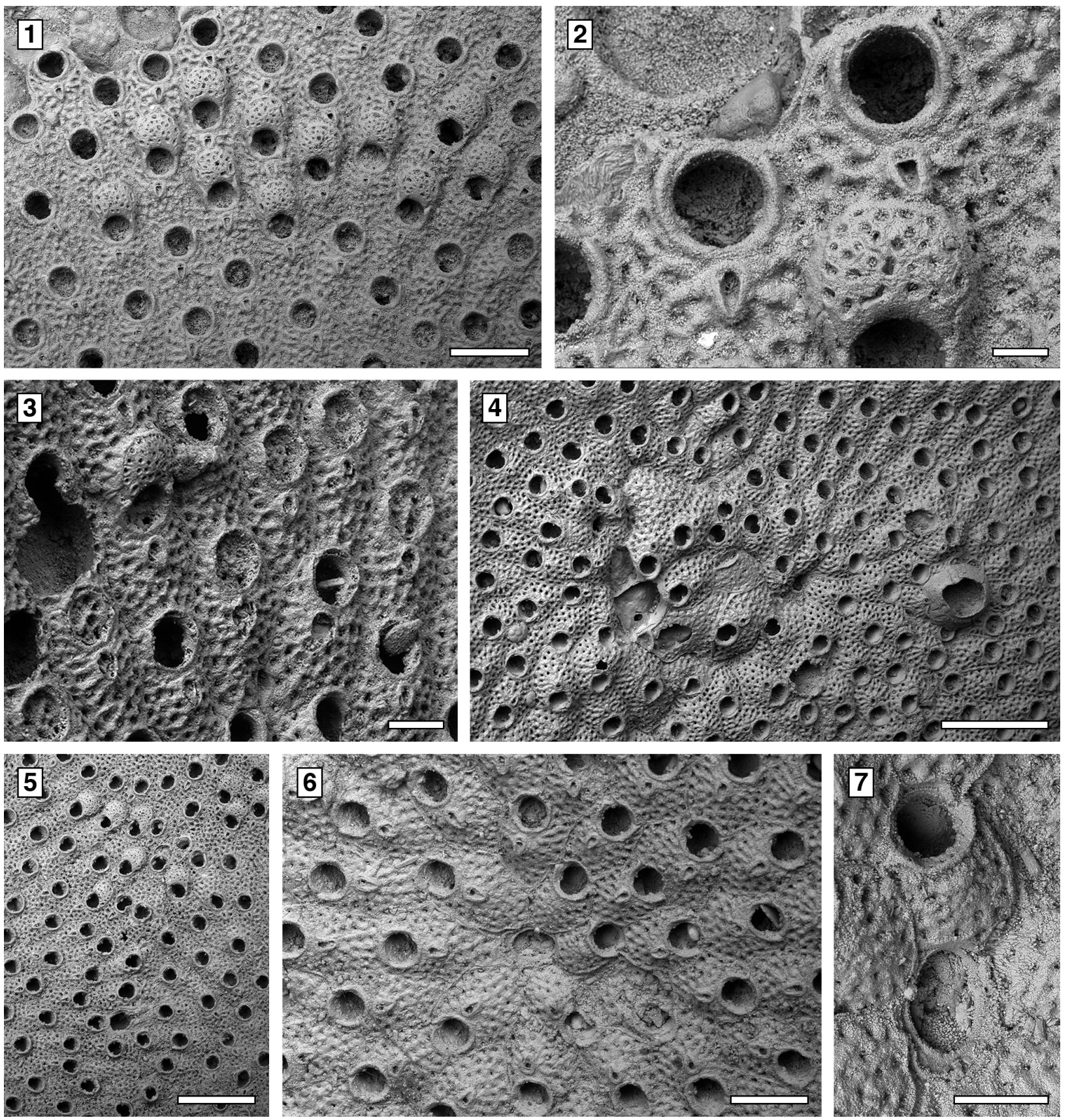

FIGURE 31. Metroperiella reversa (Ulrich and Bassler, 1904) comb. nov., Pliocene, lower Tamiami Formation Units 10/ 11. 1-2, UF 305799 (Shell 343). 1, group of ovicellate and non-ovicellate zooids $(500 \mu \mathrm{m})$. 2, close-up of two orifices with suboral avicularia and an ovicell $(100 \mu \mathrm{m}) .3$, UF 305800 (Shell 23), group of zooids with closure plates $(200 \mu \mathrm{m})$. 4, UF 305801 (Shell 3), group of autozooids and irregularly shaped kenozooids filling the gap resulting from self-overgrowth (1 mm). 5, UF 305802 (Shell 461), irregularly shaped kenozooids at the junction between two abutting colonies (1 mm). 6-7, UF 305803 (Shell 2). 6, tatiform ancestrula and early astogeny $(400 \mu \mathrm{m})$. 7, close-up of the tatiform ancestrula and first budded zooid $(200 \mu \mathrm{m})$.

from the ancestrula, smaller than later autozooids; distal periancestrular bud usually lacking an avicularium (Figure 31.7), which can be either present or absent in the two distolateral periancestrular buds.
Measurements $(\mu \mathrm{m})$. ZL 628 $\pm 39,576-697(1,10)$;

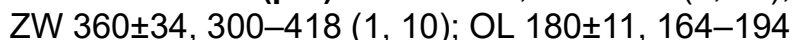

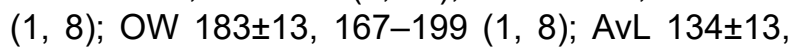

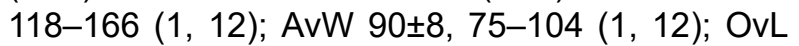



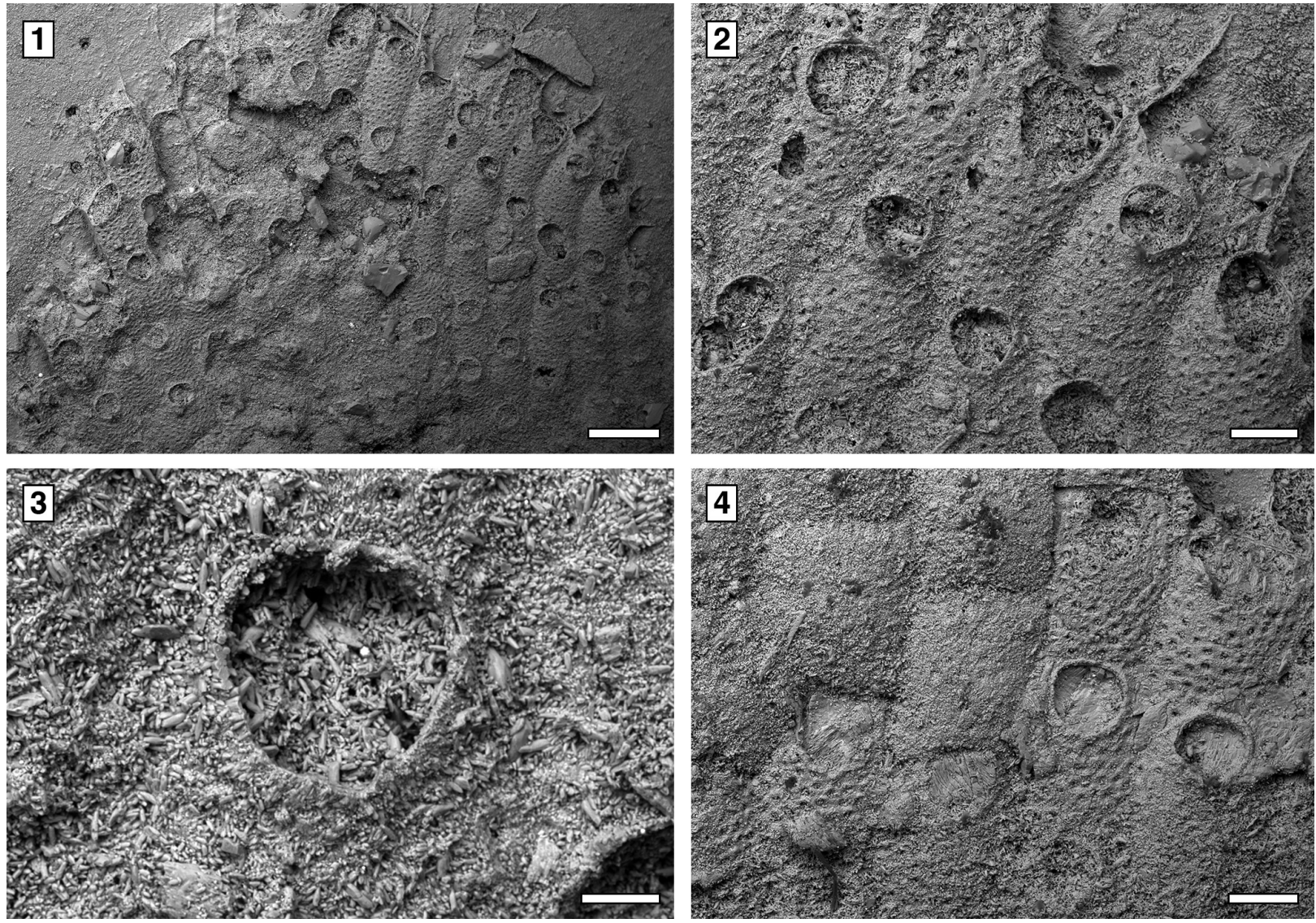

FIGURE 32. Watersipora? sp., UF 305804 (Shell 427), Pliocene, lower Tamiami Formation Units 10/11. 1, part of a colony $(500 \mu \mathrm{m}) .2$, group of autozooids $(200 \mu \mathrm{m})$. 3, close-up of an orifice $(50 \mu \mathrm{m}) .4$, ?kenozooids lacking an aperture $(200 \mu \mathrm{m})$.

214 $\pm 14,195-240$ (1, 12); OvW 296 $\pm 12,280-315$ $(1,12)$.

Remarks. This species was first described from the Miocene of Maryland and subsequently reported from the Pliocene of North Carolina (Canu and Bassler, 1923). It is better accommodated in Metroperiella Canu and Bassler, 1917 as Porella Gray, 1848, to which Canu and Bassler (1923) reassigned the species, is characterized by an imperforate frontal shield with marginal areolar pores only, a suboral avicularium usually embedded in the peristome and ovicells that are imperforate or have a single small pore.

Family Watersiporidae Vigneaux, 1949

Genus Watersipora Neviani, 1896

Watersipora? sp.

Figure 32

Figured material. UF 305804 (Shell 427). Pliocene, lower Tamiami Formation.

Description. Colony encrusting, multiserial, unilaminar (Figure 32.1). Autozooids distinct, with shallow interzooidal furrows, subrectangular, arran- ged in alternating parallel rows, elongate (mean L/ $W$ 1.82). Frontal shield convex, granular, evenly pseudoporous (Figure 32.2); pseudopores numbering $45-55$, rounded, about $10-15 \mu \mathrm{m}$ in diameter. Orifice subcircular to oval, condyles seemingly present (Figure 32.3); oral spines absent. Avicularia, ovicells and ancestrula not observed. Apparent kenozooids lacking an aperture common (Figure 32.4).

Measurements $(\boldsymbol{\mu m})$. ZL 640 $\pm 50,544-707(1,12)$; ZW 353 \pm 35 , 312-402 (1, 12); OL 175 $\pm 11,160-190$ $(1,8)$; OW 172 $\pm 15,152-198(1,8)$.

Remarks. The poor preservation of all available specimens precludes a more accurate identification for this species, which is tentatively referred to Watersipora based only on the shape of zooids and orifice and on the pseudoporous frontal shield. The specimen figured here is the only one preserving the shape of the orifice, although poorly and only for some zooids; all of the remaining specimens in the Tamiami Formation material consist of a few subrectangular ?kenozooids totally lacking 

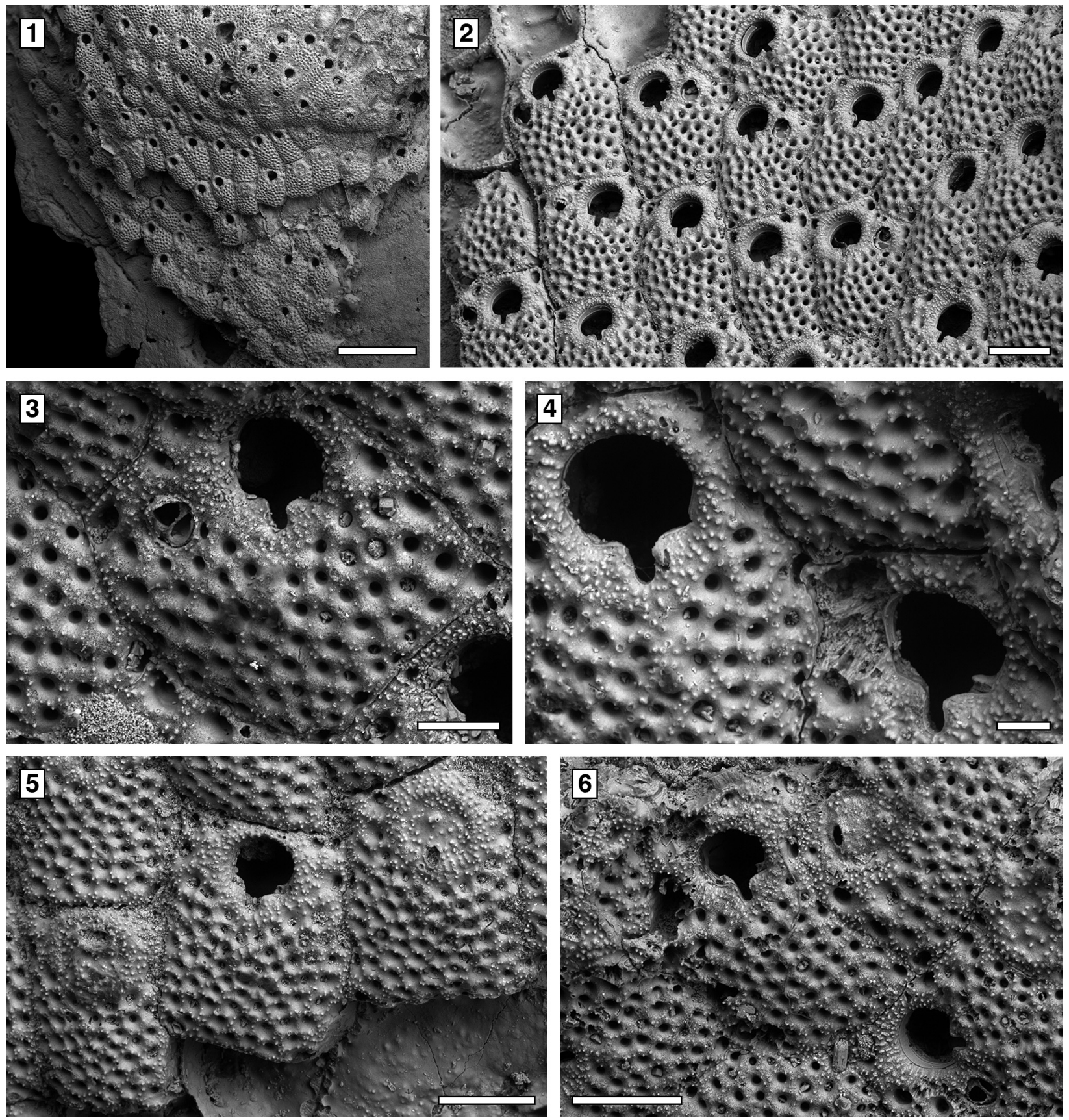

FIGURE 33. Stylopoma leverhulme Di Martino, Taylor, and Portell, 2017, UF 305805 (Shell 27), Pliocene, lower Tamiami Formation Units 10/11. 1, general view of a multi-layered colony $(1 \mathrm{~mm})$. 2, group of autozooids $(200 \mu \mathrm{m})$. 3 , close-up of an autozooid with an avicularium lateral to the orifice $(100 \mu \mathrm{m})$. 4, close-up of two orifices $(50 \mu \mathrm{m})$. 5-6, autozooids with closure plates $(200 \mu \mathrm{m})$.

apertures. The general appearance of this species recalls some Neogene species that Canu and Bassler (1923) identified as Dakaria, which is now recognized as junior synonym of Watersipora (Vieira et al., 2014), and await revision.

Superfamily Schizoporelloidea Jullien, 1883

Family Schizoporellidae Jullien, 1883
Genus Stylopoma Levinsen, 1909

Stylopoma leverhulme Di Martino, Taylor, and

Portell, 2017

Figure 33

2017 Stylopoma leverhulme Di Martino, Taylor, and Portell, p. 157, figure 46. 
Figured material. UF 305805 (Shell 27). Pliocene, lower Tamiami Formation.

Description. Colony encrusting, multiserial, multilaminar (Figure 33.1). Autozooids with distinct interzooidal furrows, rectangular to irregularly polygonal, arranged in alternating parallel rows, slightly longer than wide (mean L/W 1.30). Frontal shield flat to slightly convex, sharply granular, evenly and densely perforated by $45-65$ pseudopores, absent around the orifice (Figure 33.2-4); pseudopores circular, funnel-shaped, about $15 \mu \mathrm{m}$ in external diameter and $12 \mu \mathrm{m}$ in internal diameter, situated at the centres of a polygonal facets; marginal areolar pores placed at zooidal corners distinguished from pseudopores by being larger, 20-30 $\mu \mathrm{m}$ in diameter, and not evenly funnel-shaped. Primary orifice wider than long, $100 \mu \mathrm{m}$ long (excluding sinus) by $120 \mu \mathrm{m}$ wide, transversely D-shaped, proximal edge straight, sloping into a deep, slit-like sinus about $40 \mu \mathrm{m}$ long by $20 \mu \mathrm{m}$ wide (Figure 33.4); condyles robust, rectangular with rounded edges, smooth (Figure 33.6). Adventitious avicularium single or absent, small, teardrop-shaped, located laterally of the orifice, directed distally or distolaterally (Figure 33.2-3); rostrum pointed triangular, raised; crossbar complete. Vicarious avicularia and ovicells not observed. Closure plates common (Figure 33.5-6).

Measurements $(\mu \mathrm{m})$. ZL 407 $\pm 40,342-476(1,15)$;

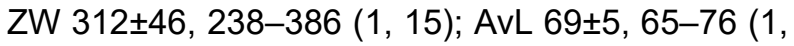
4); AvW 57 $\pm 2,54-58(1,4)$.

Remarks. Stylopoma leverhulme was first described from the lower Miocene Chipola Formation of Florida. Although ovicells and vicarious avicularia were lacking in the few colonies available from the Tamiami Formation, the identity is confirmed by the zooidal measurements, the sharply granular appearance of the frontal shield, as well as the shape of the orificial sinus and the shape and position of the adventitious avicularium.

Family Stomachetosellidae Canu and Bassler, 1917

Genus Cycloperiella Canu and Bassler, 1923

Cycloperiella rubra Canu and Bassler, 1923

Figure 34

1923 Cycloperiella rubra Canu and Bassler, p. 137, pl. 21, figures 5-9.

Figured material. UF 305806 (Shell 15); UF 305807 (Shell 28). Pliocene, lower Tamiami Formation.

Description. Colony encrusting, multiserial, unilaminar, sheet-like (Figure 34.1, 4). Pore-chamber windows present along zooidal margins (Figure 34.1-2). Autozooids distinct, with shallow interzooi- dal furrows, quincuncially arranged, hexagonal, longer than wide (mean L/W 1.33). Frontal shield convex, finely granular, densely perforated, except around the orifice, by 30-40 circular pseudopores, $15-20 \mu \mathrm{m}$ in diameter; marginal areolar pores distinguishable at proximal and lateral zooidal corners, absent distally, larger than pseudopores, 25$45 \mu \mathrm{m}$ in diameter. Orifice almost equidimensional, located terminally, the distal edge produced partly by the next distal zooid; two small, pointed condyles medially directed and proximally located separate a rounded anter from a broad, shallowly concave proximal margin (Figure 34.3). Oral spine bases absent. Avicularia adventitious, varying in number and distribution, placed laterally to the orifice or proximolaterally on the frontal shield, small, pear-shaped or pointed triangular, proximally or distolaterally directed (Figure 34.2, 6). Ovicells of the lepralielliform type, large, formed by the next distal zooid and occupying half of its frontal surface (Figure 34.4-6); ectooecium calcified, granular with numerous round pseudopores covered by the secondary calcification formed from the distal and distolateral neighbouring zooids and separated by thin raised sutures; a peristomial collar surrounds the orifice in ovicellate zooids (Figure 34.6). Ancestrula not observed.

Measurements $(\mu \mathrm{m})$. ZL 545 $\pm 53,443-633(3,20)$; ZW 409 $\pm 40,320-461$ (3, 20); OL 127 $\pm 5,119-136$ $(2,12)$; OW 130 $\pm 6,122-143$ (2, 12); AvL 108 \pm 12 , 86-124 (2, 12); AvW 72 \pm , 61-84 (2, 12); OvL 228 $\pm 14,207-257(1,10)$; OvW 330 $\pm 14,308-353$ $(1,10)$.

Remarks. Canu and Bassler (1923) reported Cycloperiella rubra from several Pliocene and Pleistocene deposits in North America, including the Pliocene Duplin Formation of North Carolina and the upper Pliocene Bowden Formation (now Bowden Member, Layton Formation) of Jamaica. The genus Cycloperiella was first described by Canu and Bassler (1920, p. 431) and the type species, C. rubra, mentioned as a nomen nudum (Figure 35; USNM 68620) before the authors made the name available three years later (Canu and Bassler, 1923, p. 137). The specific name 'rubra' likely refers to the typical reddish colour of the fossils, which was probably the colour of the living colonies. Although the type material from the Pliocene of North Carolina has fewer pores (on average 20) in the frontal shield, we are skeptical that this is sufficient to introduce a new species for the Tamiami material until a more comprehensive revision has been undertaken of the genus. 

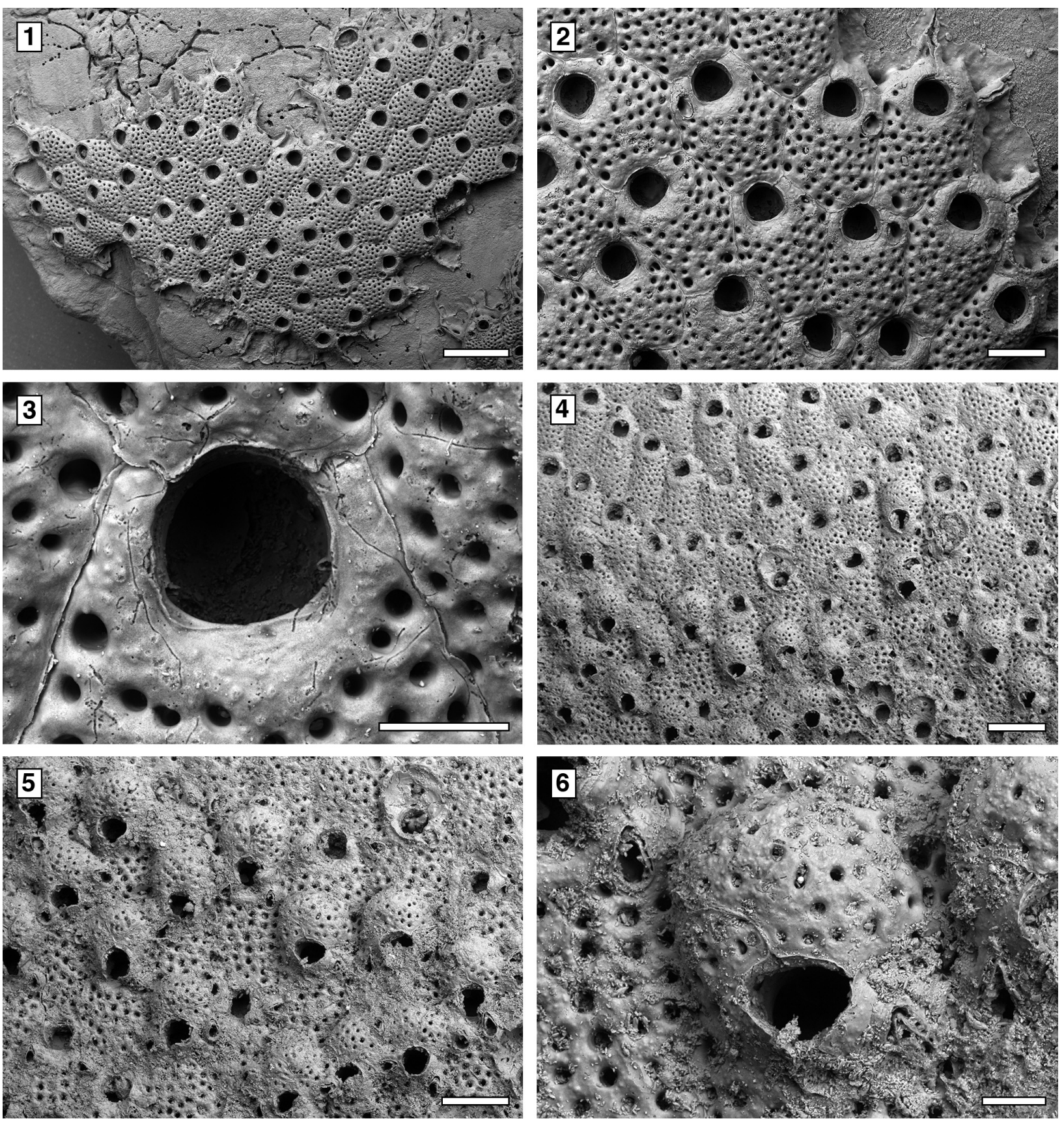

FIGURE 34. Cycloperiella rubra Canu and Bassler, 1923, Pliocene, lower Tamiami Formation Units 10/11. 1-3, UF 305806 (Shell 15). 1, general view of a colony $(500 \mu \mathrm{m})$. 2, group of autozooids, some with avicularium lateral to the orifice $(200 \mu \mathrm{m})$. 3, close-up of the orifice $(100 \mu \mathrm{m})$. 4-6, UF 305807 (Shell 28). 4, group of ovicellate and non-ovicellate zooids $(500 \mu \mathrm{m}) .5$, group of ovicellate zooids $(300 \mu \mathrm{m}) . \mathbf{6}$, close-up of an ovicell with peristomial collar $(100 \mu \mathrm{m})$.

Family Hippaliosinidae Winston, 2005

Genus Hippaliosina Canu, 1918

Hippaliosina rostrigera (Smitt, 1873)

Figure 36

1873 Escharella rostrigera Smitt, p. 57, figures 203-205.
2005

Hippaliosina rostrigera Winston, p. 75, figures 200-206.

2017 Hippaliosina rostrigera Di Martino et al., p. 163 , figure 50.

Figured material. UF 305808 (Shell 22). Pliocene, lower Tamiami Formation. 

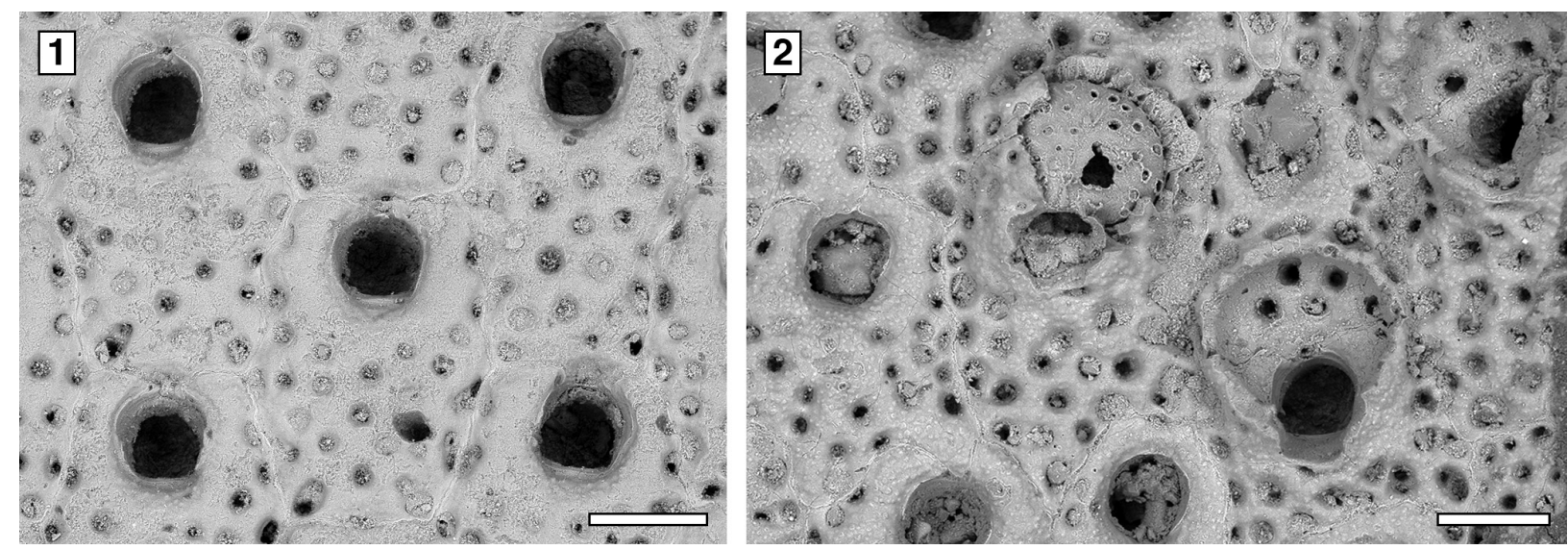

FIGURE 35. Cycloperiella rubra Canu and Bassler, 1923, syntype USNM 68620, Pliocene, North Carolina, USA. 1, group of autozooids $(200 \mu \mathrm{m})$. 2, ovicellate zooids $(200 \mu \mathrm{m})$.

Description. Colony encrusting, multiserial, unilaminar, sheet-like (Figure 36.1). Pore-chamber windows oval, 15-25 $\mu \mathrm{m}$ long, visible along zooidal margins. Autozooids distinct, bordered by narrow grooves, hexagonal to polygonal in shape with undulose margins, longer than broad (mean L/W 1.60). Frontal shield flat to slightly convex, coarsely granular, imperforate apart from a continuous row of marginal areolar pores, teardrop-shaped, outwardly sloping, 10-30 $\mu \mathrm{m}$ long. Orifice distally placed, keyhole-shaped (i.e., cleithridiate), longer than broad; two pointed, downwardly directed condyles separating a horseshoe-shaped anter from a bowl-shaped sinus. Adventitious avicularia lateral to the orifice usually single, occasionally paired, their bases slightly above the proximal margin of the orifice or distally placed, distally and inwardly directed, pivotal bar absent (Figure 36.2). Maternal zooids and kenozooids not observed. Ancestrula not seen.

Measurements $(\boldsymbol{\mu m})$. ZL 402 $\pm 54,319-482(1,10)$;

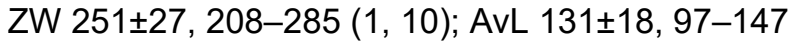
$(1,10)$; AvW 66 \pm 9 , 43-77 (1, 10).

Remarks. Hippaliosina rostrigera ranges from the early Miocene to recent. It has been recorded in Virginia, North Carolina, South Carolina, and Florida, as well as Costa Rica. The zooidal measurements of the Tamiami Formation specimens are similar to those of the Chipola Formation specimens described by Di Martino et al. (2017), but smaller than the type specimen figured in Winston (2005).

Family Microporellidae Hincks, 1879

Genus Microporella Hincks, 1877

Microporella sarasotaensis sp. nov.

Figure 37
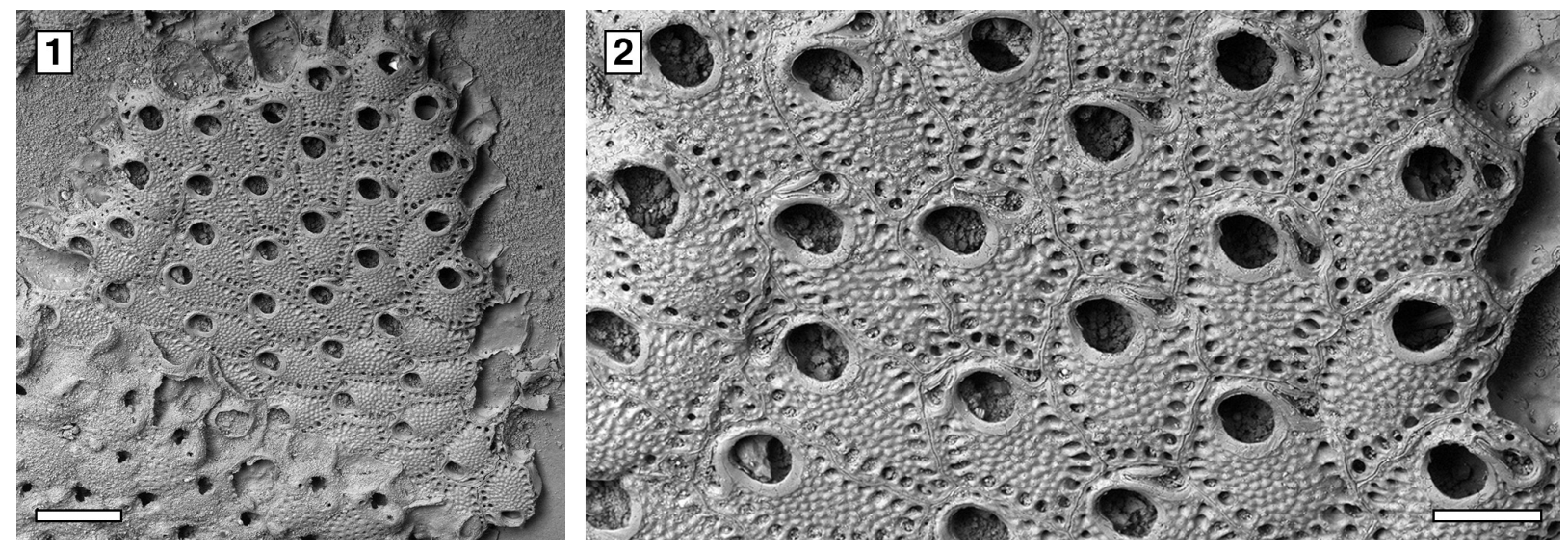

FIGURE 36. Hippaliosina rostrigera (Smitt, 1873), UF 305808 (Shell 22), Pliocene, lower Tamiami Formation Units $10 / 11$. 1, tilted view of a colony $(400 \mu \mathrm{m}) .2$, group of autozooids with adventitious avicularia $(200 \mu \mathrm{m})$. 

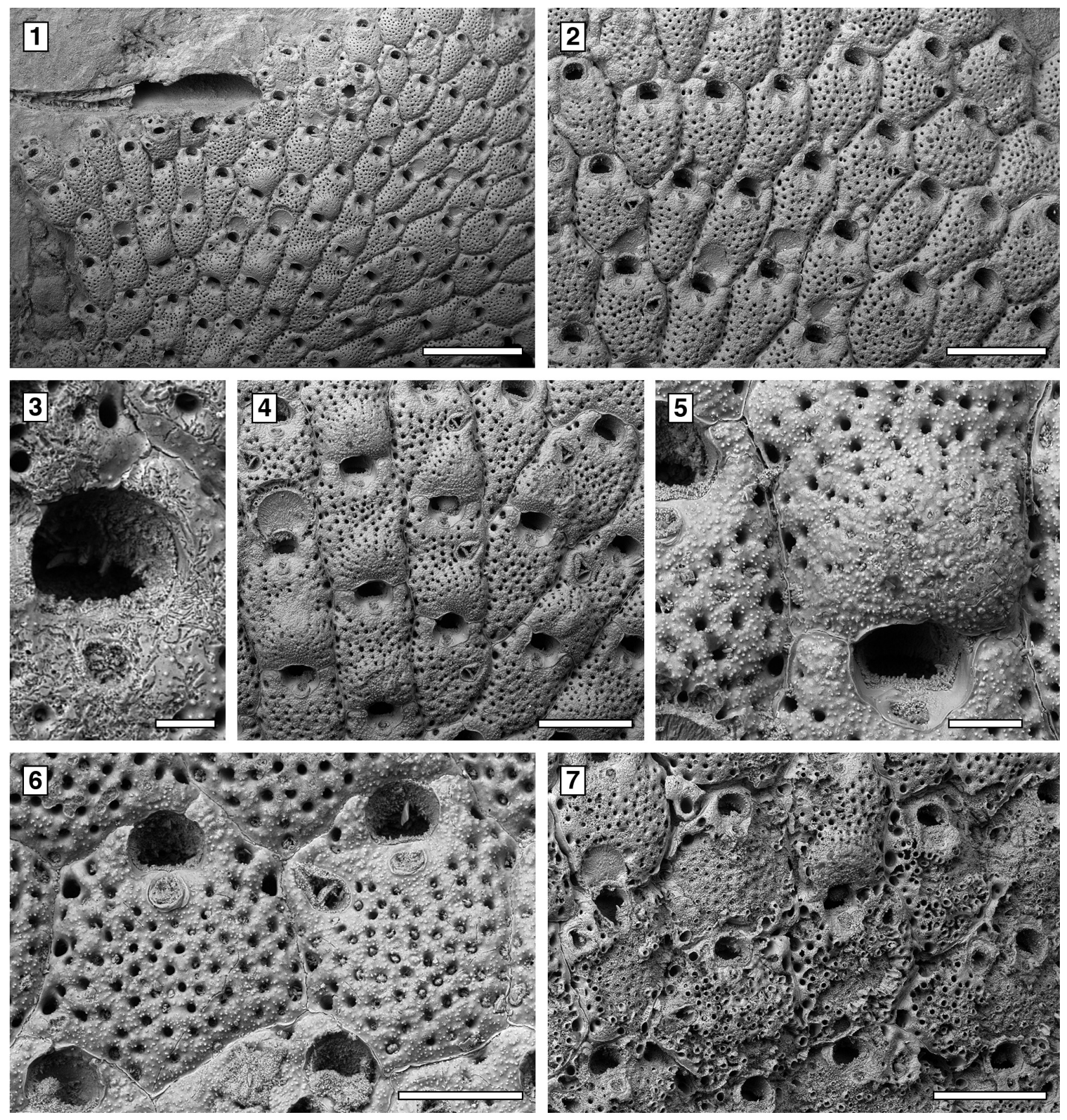

FIGURE 37. Microporella sarasotaensis sp. nov., Pliocene, lower Tamiami Formation Units 10/11. 1-5, holotype UF 305809 (Shell 374). 1, general view of part of the colony $(1 \mathrm{~mm}) .2$, group of autozooids $(500 \mu \mathrm{m})$. 3, close-up of the cribrate ascopore $(50 \mu \mathrm{m}) .4$, group of ovicellate zooids $(400 \mu \mathrm{m}) . \mathbf{5}$, close-up of an ovicell $(100 \mu \mathrm{m}) . \mathbf{6}$, paratype UF 305810 (Shell 14), close-up of two autozooids $(200 \mu \mathrm{m})$. 7, paratype UF 305811 (Shell 21), dissolution or abrasion of some zooids $(400 \mu \mathrm{m})$.

\section{zoobank.org/CC6E3CEE-D1F6-40B5-B581-EFBFCB388E6B}

Type material. Holotype UF 305809 (Shell 374); paratypes UF 305810 (Shell 14) and UF 305811 (Shell 21). Pliocene, lower Tamiami Formation. Etymology. Named after the type locality, Sarasota.
Diagnosis. Colony encrusting forming extensive sheets. Pore-chamber windows present. Autozooids with finely granular and evenly pseudoporous frontal shield, except around the orifice and ascopore; marginal areolar pores at zooidal corners. Ascopore rounded, cribrate, adjacent to the orifice. Orifice semicircular, with denticulate proximal mar- 
gin. Oral spines absent. Avicularium adventitious, single, located at about zooidal mid-length, triangular to acicular, directed distolaterally, with complete crossbar. Ovicell finely granular around an imperforate centre.

Description. Colony encrusting, multiserial, unilaminar, developing extensive sheets (>100 zooids) (Figure 37.1). Pore-chamber windows visible at colony growing edge, numerous, closely spaced, rounded to elliptical, 35-60 $\mu \mathrm{m}$ long by $25-30 \mu \mathrm{m}$ wide (Figure 37.1). Autozooids distinct, with shallow interzooidal furrows and a thin lamina of smooth, raised calcification, hexagonal to rectangular or irregularly polygonal, commonly arranged in well-defined longitudinal rows (Figure 37.2, 4) but irregularly arranged when different lobes of the same colony converge, longer than wide (mean L/ $\mathrm{W}$ 1.43). Frontal shield convex, finely granular, evenly pseudoporous, except for an imperforate band about $50 \mu \mathrm{m}$ wide surrounding the orifice and including the ascopore (Figure 37.2); pseudopores $40-55$, on average 45 , circular, $10-15 \mu \mathrm{m}$ in diameter; a few scattered marginal areolar pores located at zooidal corners, larger than pseudopores, rounded to elliptical, 30-40 $\mu \mathrm{m}$ long; ascopore rounded, 50-65 $\mu \mathrm{m}$ in diameter, cribrate (Figure 37.3), placed very close to the orifice, embedded in the proximal part of the peristome in ovicellate zooids (Figure 37.5), surrounded by a raised margin of smooth calcification, more extensive proximally. Orifice semicircular, with denticulate proximal margin, no condyles; oral spine bases absent (Figure 37.2, 6). Avicularia adventitious, generally single, sometimes absent, placed on either side of the autozooid, at about midlength, much below the ascopore, teardrop-shaped (Figure 37.2, 4-6); rostrum rounded triangular, sometimes pointed acicular, directed distolaterally; crossbar complete; intramural buds observed in avicularia. Ovicell embedded in the distal zooid, finely granular proximally, with a few, scattered pseudopores distally, smaller than those on the frontal shield (Figure 37.4); orifice in ovicellate zooid hidden distally by the recumbent ovicell, deeper than in non-ovicellate zooids because of the development of a peristome that also includes the ascopore (Figure 37.5). Ancestrula not seen.

Measurements $(\mu \mathrm{m})$. ZL 535 $\pm 63,424-672(2,20)$; ZW 375 \pm 52 , 293-489 (2, 20); OL 108 $\pm 10,95-128$ $(2,15)$; OW 138 $\pm 12,122-159$ (2, 15); AvL 112 \pm 14 ,

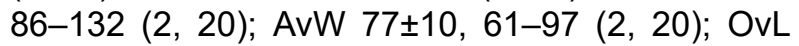
246 \pm 22 , 213-281 (2, 15); OvW 323 $\pm 24,289-385$ $(2,15)$.
Remarks. Among fossil and modern western Atlantic species of Microporella, only a few lack oral spines, which is one of the main features of $M$. sarasotaensis sp. nov., distinguishing it from congeneric species found in the Tamiami Formation material. Microporella bifoliata Ulrich and Bassler, 1904 and M. inflata Ulrich and Bassler, 1904 both from the Miocene of Maryland, differ in having erect, bifoliate colonies and smooth-surfaced zooids and ascopores more distant from the orifice, respectively; $M$. cucullata Canu and Bassler, 1928b, from Brazil differs in having a distally raised peristome; M. normani Canu and Bassler, 1928a, allegedly found alive in Madeira and as a fossil in the Pliocene of Panama, differs in having a larger avicularium closer to the orifice and a crescentic ascopore.

Microporella tamiamiensis sp. nov. Figure 38

zoobank.org/E368247E-2354-4357-99DE-C9A8AE397372

Type material. Holotype UF 305812 (Shell 3); paratype UF 305813 (Shell 29). Pliocene, lower Tamiami Formation.

Etymology. Named after its type lithostratigraphic unit, the Tamiami Formation.

Diagnosis. Colony encrusting, forming extensive sheets. Pore-chamber windows present. Autozooids with finely granular and evenly and densely pseudoporous frontal shields, except around the orifice and ascopore. Ascopore crescentic, denticulate, placed in a depression below the orifice and surrounded by a slightly raised collar. Orifice semicircular, with denticulate proximal margin. Oral spines $3-5$, commonly 3 , hidden in ovicellate zooids. Avicularium adventitious, single, located at zooidal lateral corners, triangular, directed distolaterally, with complete crossbar. Ovicell evenly pseudoporous; peristome developing as two lateral flaps.

Description. Colony encrusting, multiserial, unilaminar, developing extensive sheets (>100 zooids) (Figure 38.1). Pore-chamber windows visible at colony growing edge, numerous, closely spaced, rounded to elliptical, 30-50 $\mu \mathrm{m}$ long by 25-30 $\mu \mathrm{m}$ wide (Figure 38.3, 5). Autozooids distinct, with shallow interzooidal furrows, rounded hexagonal to irregularly polygonal, quincuncially arranged, slightly longer than wide (mean L/W 1.22). Frontal shield convex, finely granular, evenly and densely pseudoporous, except for an imperforate band about $95 \mu \mathrm{m}$ large, surrounding the orifice and the ascopore (Figure 38.2-3); pseudopores 80-110, on average 90 , circular, $12-20 \mu \mathrm{m}$ in diameter; marginal areolar pores undistinguished from pseu- 

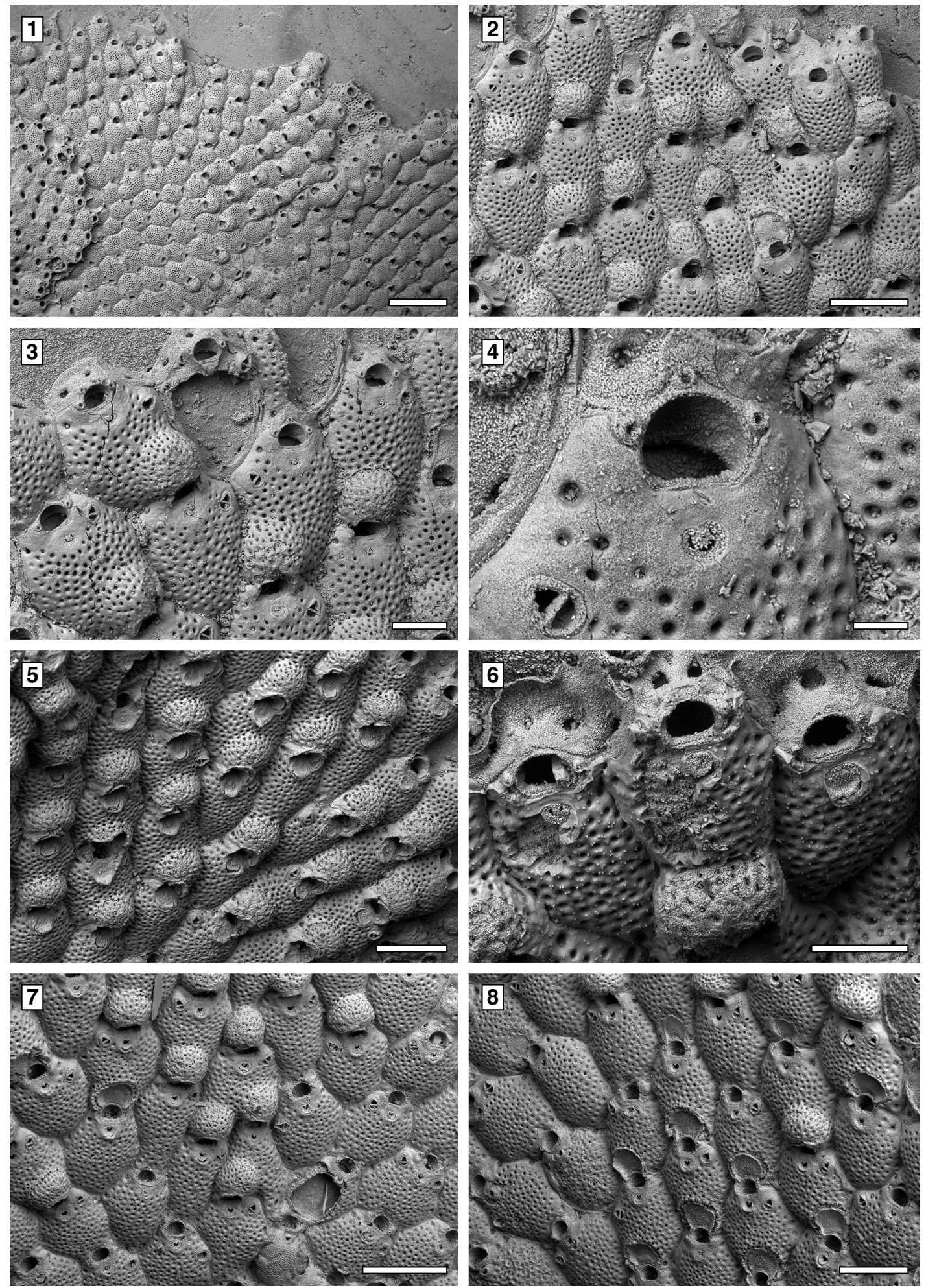

FIGURE 38. Microporella tamiamiensis sp. nov., Pliocene, lower Tamiami Formation Units 10/11. 1-6, holotype UF 305812 (Shell 3). 1, general view of part of the colony $(1 \mathrm{~mm})$. $\mathbf{2}$, group of ovicellate and non-ovicellate zooids $(500$ $\mu \mathrm{m})$. 3, group of zooids at colony growing edge showing pore-chamber windows $(200 \mu \mathrm{m}) .4$, close-up of an orifice with three oral spine bases $(50 \mu \mathrm{m}) .5$, group of tilted ovicellate zooids showing the lateral flaps $(400 \mu \mathrm{m})$. 6, close-up of zooids showing pore-chamber windows $(200 \mu \mathrm{m})$. 7-8, paratype UF 305813 (Shell 29), group of zooids showing a more developed proximal rim of the ascopore $(\mathbf{7}, 500 \mu \mathrm{m} ; \mathbf{8}, 400 \mu \mathrm{m})$. 
dopores, except for a few cases when located at zooidal corners, slightly larger and circular, about $25 \mu \mathrm{m}$ in diameter; ascopore crescent-shaped, 35$65 \mu \mathrm{m}$ in diameter, denticulate, placed in a depression about $35 \mu \mathrm{m}$ below the orifice and surrounded by a slightly raised collar, often more developed proximally (Figure 38.4-5). Orifice semicircular, with denticulate proximal margin (Figure 38.4); no condyles. Oral spine bases 3 (one mediodistal and two mediolateral; Figure 38.4) or 4 (one distal pair and one mediolateral pair; Figure 38.3), most commonly 3, 5 observed only once, 20-30 $\mu \mathrm{m}$ in diameter. Avicularia adventitious, generally single, sometimes absent, located on either side of the autozooid, commonly placed at the lateral corner at the same level as the ascopore, rarely at zooidal mid-length below the ascopore, teardrop-shaped (Figure 38.3-4); rostrum triangular, directed distolaterally; crossbar complete. Ovicell embedded in the proximal part of the distal zooid, finely granular and evenly pseudoporous (Figure 38.3, 7-8); no spines visible in ovicellate zooids, hidden by the development of a peristome consisting of two lateral flaps (Figure 38.5). Ancestrula not seen.

Measurements $(\mu \mathrm{m})$. ZL 512 $\pm 46,444-652(2,20)$; ZW 419 \pm 52 , 333-518 (2, 20); OL 82 $\pm 6,75-94$ (2, 16); OW 102 $\pm 4,94-108$ (2, 16); AvL 79 $\pm 8,64-95$

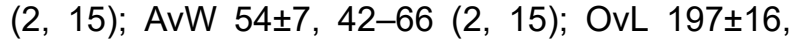
173-231 (2, 20); OvW 253 $\pm 20,220-291$ (2, 20).

Remarks. At first sight Microporella tamiamiensis sp. nov. is apparently very similar to its sympatric congener Microporella sarasotaensis sp. nov. Indeed, both species form very extensive sheets and the zooids are of similar length. They also share the finely granular frontal shield of the zooids and the denticulate proximal border of the orifice. However, there are several differences. In M. tamiamiensis sp. nov. the zooids are wider and have a lower L/W ratio (1.22 vs 1.43 ), orifices and avicularia are both smaller, frontal shields have double the number of pseudopores (on average 90 vs 45), oral spines are present, ovicells evenly pseudoporous, peristomes developed laterally as two flaps, and the ascopore is denticulate. Among fossil and living western Atlantic species with 3-4 oral spine bases, the following species differ from $M$. tamiamiensis sp. nov.: Microporella curta Almeida, Souza, Menegola, and Vieira, 2017 has zooids separated by raised walls, a nodular frontal shield and personate ovicells; $M$. fissurifera Canu and Bassler, 1923 has frontal shields with fewer pseudopores, the ascopore is closer to the orifice and there are large, slit-like pore-chamber windows; $M$. protea Winston, 2005 has a pustulose frontal shield with fewer, larger pseudopores, smaller autozooids and ovicells but larger avicularium; $M$. proxima Ramalho, Muricy and Taylor, 2011 has smaller autozooids, a nodular frontal shield with fewer, larger pseudopores, and avicularia that are more proximally placed.

\section{Microporella cf. pontifica Osburn, 1952} Figure 39

cf. 1952 Microporella pontifica Osburn, p. 383, pl. 44, figure 5.

Figured material. UF 305814 (Shell 15); UF 305815 (Shell 30); UF 305816 (Shell 12). Pliocene, lower Tamiami Formation.

Description. Colony encrusting, multiserial, unilaminar, generally forming small spots ( $<20$ zooids) but sometimes developing more extensive patches (50-100 zooids) (Figure 39.1). Pore-chamber windows visible at colony growing edge, numerous, closely spaced, rounded to elliptical, 40-60 $\mu \mathrm{m}$ long by $25-45 \mu \mathrm{m}$ wide (Figure 39.1). Autozooids distinct with shallow interzooidal furrows and a thin lamina of smooth, raised calcification, rounded hexagonal, quincuncially arranged, slightly longer than wide (mean L/W 1.18). Frontal shield undulose, smooth and nodular, evenly and densely pseudoporous, except laterally to the orifice and laterally and distally to the avicularium (Figure 39.2); pseudopores $60-75$, on average 65 , circular, 15-18 $\mu \mathrm{m}$ in diameter; a few, scattered, marginal areolar pores adjacent to the zooidal margin, rounded to elliptical, 20-25 $\mu \mathrm{m}$ long; ascopore crescent-shaped, 50-60 $\mu \mathrm{m}$ in diameter, denticulate (Figure 39.4), placed in a depression just below the orifice and surrounded by a slightly raised collar, often more developed proximally. Orifice semicircular, with slightly denticulate proximal and distal margins, no condyles; a crenulated margin of cusps and lobes, the latter in the position of the oral spines, is formed by the frontal shield of the distal zooid (Figure 39.4). Oral spine bases 57 , most commonly 5,7 observed only in a few zooids, $20-30 \mu \mathrm{m}$ in diameter. Avicularia adventitious, generally single, rarely absent or paired, located on either side of the autozooid, commonly placed at the lateral zooidal corner, at the same level as the ascopore or below, teardrop-shaped; rostrum funnel-shaped, channeled, directed distolaterally; crossbar complete. Ovicell embedded in the proximal part of the next distal zooid, nodular and evenly pseudoporous like the frontal shield but with smaller pseudopores (Figure 39.2-3); no spines visible in ovicellate zooids, possibly hidden by the development of a collar consisting of two lateral flaps that can fuse into a bridge (personate 

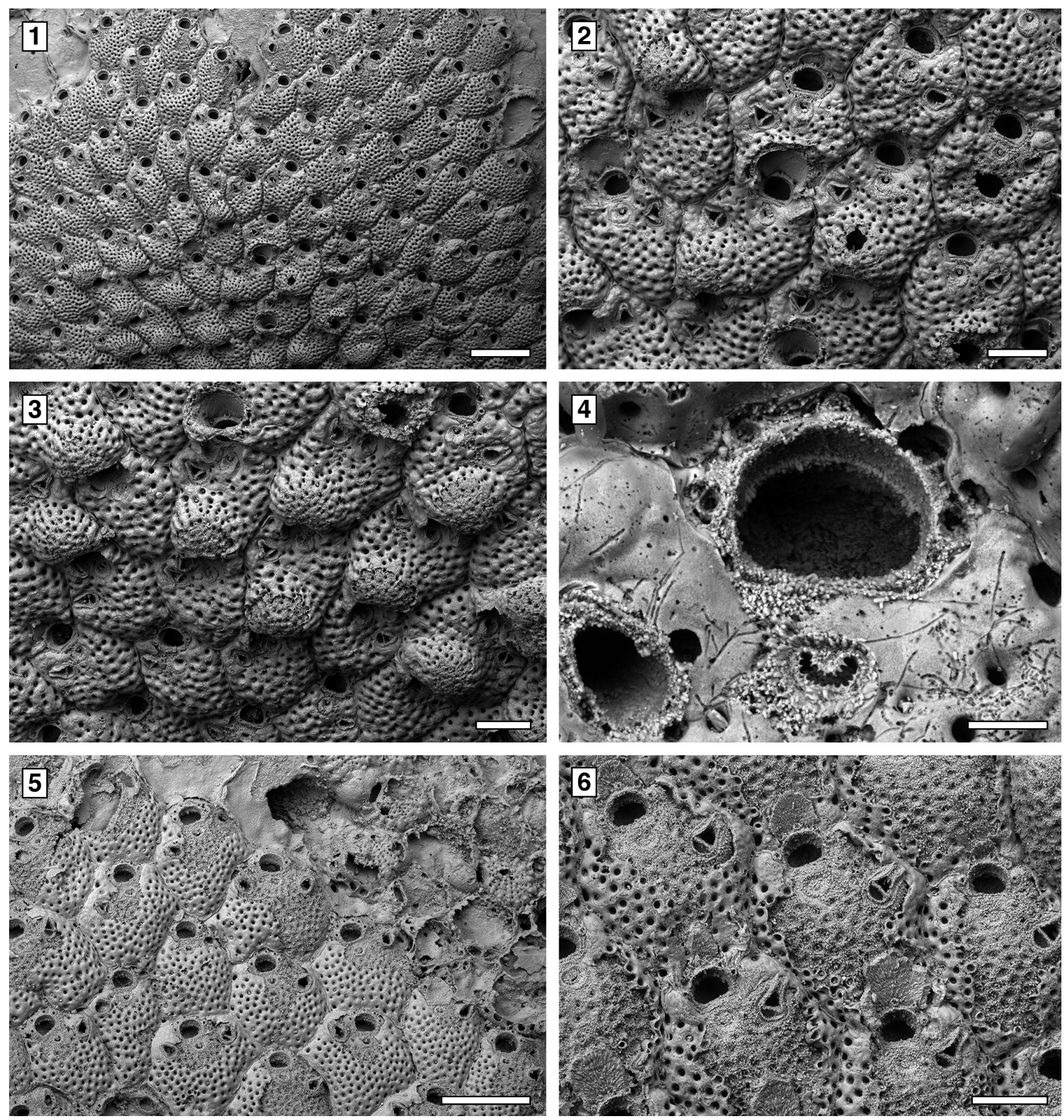

FIGURE 39. Microporella cf. pontifica Osburn, 1952, Pliocene, lower Tamiami Formation Units 10/11. 1-4, UF 305814 (Shell 15). 1, general view of part of the colony $(500 \mu \mathrm{m}) .2$, group of ovicellate and non-ovicellate zooids $(200 \mu \mathrm{m}) .3$, group of ovicellate zooids, one on the top left with a peristomial bridge $(200 \mu \mathrm{m}) .4$, close-up of the orifice (with cormidial cusps and lobes in the position of oral spine bases) and denticulate ascopore $(40 \mu \mathrm{m})$. 5, UF 305815 (Shell 30 ), group of autozooids, some with paired avicularia $(400 \mu \mathrm{m})$. 6, UF 305816 (Shell 12), dissolution or abrasion of some zooids $(200 \mu \mathrm{m})$.

ovicell) (Figure 39.3). Ancestrula similar to later autozooids but smaller, about $325 \mu \mathrm{m}$ long by 220 $\mu \mathrm{m}$ wide, lacking an avicularium, budding one distal and two distolateral autozooids (335-390 $\mu \mathrm{m}$ long by $255-270 \mu \mathrm{m}$ wide), surrounded by six autozooids in total.
Measurements ( $\mu \mathrm{m})$. ZL 476 $\pm 28,426-533(2,20)$; ZW 402 $\pm 57,304-505$ (2, 20); OL 92 $\pm 5,83-100$ (2, 15); OW 112 $\pm 6,103-121$ (2, 15); AvL 108 $\pm 8,92-$ 127 (2, 15); AvW 79 \pm , 66-94 (2, 15); OvL 211 \pm 20 ,

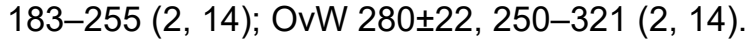


Remarks. This species is very similar in its general appearance to Microporella pontifica Osburn, 1952, a recent species found off the Pacific coast of Mexico and in the Gulf of California at 36-110 m depth. Microporella pontifica is similar to the fossil species in having up to six oral spines, orifice, and avicularium similar in size, and the peristome extended proximally across the orifice dividing the orifice from the ascopore. The latter feature seems constant in M. pontifica, while it has been observed only once in the Tamiami specimens, in which most often the peristome is limited to the lateral flaps, although in some instances it appears to have been broken off. Microporella protea Winston, 2005 found from Cape Hatteras to Florida also shares some similarities. Both species have a nodular frontal shield, a denticulate ascopore adjacent to the orifice, distal margin of the orifice with lobes and cusps formed by the next distal zooid (cormidial secondary orifice), and ovicellate zooids with projecting lateral flaps, which may or may not coalesce into a proximal bridge. However, the two species differ in several respects: the fossil species has a greater number of spines (5-7 vs 3-4), a larger orifice, and smaller avicularium.

Microporella cf. pontifica differs from its congeners from the Tamiami Formation in having a greater number of oral spines, ascopore placed closer to the orifice, and nodular frontal shield. All three Microporella species found in the Tamiami Formation assemblage show the same type of preservation, with the external layer of the frontal surface dissolved or abraded (Figures 37.7, 38.6, 39.5-6).

\section{Superfamily Celleporoidea Johnston, 1838 \\ Family Celleporidae Johnston, 1838 \\ Genus Pourtalesella Winston, 2005 \\ Pourtalesella chiarae sp. nov.}

Figure 40

zoobank.org/BCF678E7-DA5D-4A75-A9A3-F78018B15833

Type material. Holotype UF 305817 (Shell 3); paratypes UF 305818 (Shell 25), UF 305819 (Shell 26), UF 305820 (Shell 119). Pliocene, lower Tamiami Formation.

Etymology. Named after Dr. Chiara Lombardi (ENEA, Marine Environment Research Centre, La Spezia, Italy) for her significant contributions in the field of bryozoan biomineralization.

Diagnosis. Colony encrusting, often multiserial; autozooids rounded polygonal. Pore-chamber windows present. Frontal shield pseudoporous proximally and centrally, averaging 30 pseudopores per zooid. Orifice with robust rounded condyles, semi- circular anter and rounded V-shaped or broadly Ushaped sinus; oral spines absent. Avicularia adventitious, commonly paired, located proximolaterally to the orifice, directed distolaterally; crossbar complete. Ovicells globular; ectooecium incompletely calcified exposing an imperforate endooecium. Ancestrula with a well-developed, imperforate, smooth gymnocyst and a transversely D-shaped orifice.

Description. Colony encrusting, multiserial, uni- or multilaminar, extensive (>200 zooids) (Figure 40.1). Pore-chamber windows visible at colony growing edge (Figure 40.1). Autozooids distinct only laterally with shallow depressions, becoming indistinct through ontogeny, quincuncially arranged, rounded polygonal, longer than wide (mean L/W 1.45). Frontal shield slightly convex, granular, pseudoporous for about two-thirds of its length starting from the proximal margin, imperforate for the remaining one-third corresponding to the area surrounding the avicularia and orifice (Figure 40.2); pseudopores circular, 10-15 $\mu \mathrm{m}$ in diameter, numbering 24-36 per zooid, on average 30 . Orifice almost as long as wide, two robust rounded condyles separating a semicircular anter from a slightly narrower rounded V-shaped or broadly Ushaped sinus (Figure 40.3). Oral spine bases absent. Avicularia adventitious, small, commonly paired, rarely single, the swollen cystid lateral to the orifice with the tip of the rostrum at about the same level as the proximal margin of the orifice, elliptical with complete crossbar, distolaterally directed, sloping proximally and convergent inwardly (Figure 40.2). Ovicells globular, initially prominent, recumbent on and later during ontogeny immersed on the frontal shield of the next distal zooid (Figure 40.4-7); ectooecium incompletely calcified forming a narrow band; endooecium largely exposed, imperforate, with an uncertain number of radial ribs. Ancestrula small, very different in appearance from the budded zooids, oval, $215 \mu \mathrm{m}$ long by $180 \mu \mathrm{m}$ wide, with a well-developed, imperforate, smooth gymnocyst and a transversely D-shaped orifice, $70 \mu \mathrm{m}$ long by $110 \mu \mathrm{m}$ wide, surrounded by a slightly raised, striated rim about $15 \mu \mathrm{m}$ wide (Figure 40.8-9); presence of spines likely but uncertain owing to recrystallization; one distal and two distolateral zooids budded directly from the ancestrula.

Measurements $(\mu \mathrm{m})$. ZL 438 \pm 34 , 374-487 $(2,20)$; ZW 302 $\pm 29,261-361$ (2, 20); OL 116 $\pm 6,106-124$ (2, 10); OW 111 $\pm 7,104-125$ (2, 10); AvL 54 $\pm 5,48-$ 64 (2, 10); AvW 45 $\pm 5,38-55$ (2, 10); OvL 186 \pm 8 ,

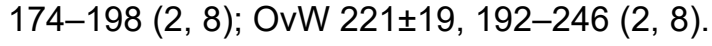



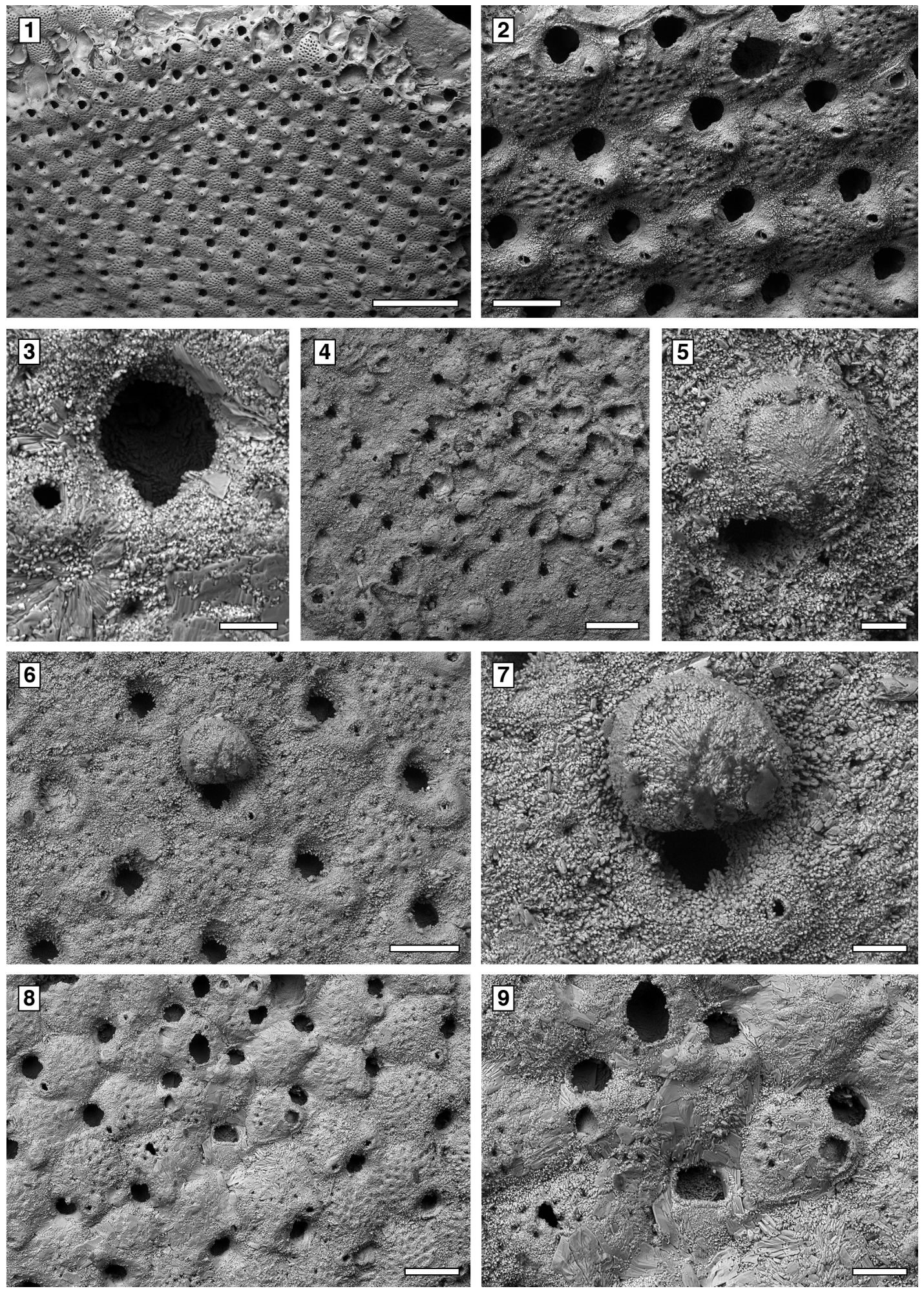

FIGURE 40. Pourtalesella chiarae sp. nov., Pliocene, lower Tamiami Formation Units 10/11. 1-2, holotype UF 305817 (Shell 3). 1, general view of the multilaminar colony $(1 \mathrm{~mm})$. 2, group of autozooids $(200 \mu \mathrm{m}) . \mathbf{3 - 5}$, paratype UF 305818 (Shell 25$)$. 3, close-up of an orifice $(40 \mu \mathrm{m})$. 4, group of ovicellate and non-ovicellate zooids $(400 \mu \mathrm{m}) . \mathbf{5}$, close-up of an ovicell $(60 \mu \mathrm{m}) .6-7$, paratype UF 305819 (Shell 26). 6, group of zooids, one ovicellate and one with a closure plate $(200 \mu \mathrm{m})$. 7, close-up of an ovicell $(60 \mu \mathrm{m}) .8-9$, paratype UF 305820 (Shell 119). 8, ancestrula and early astogeny $(200 \mu \mathrm{m}) . \mathbf{9}$, close-up of the ancestrula and first budded autozooids (100 $\mu \mathrm{m})$. 

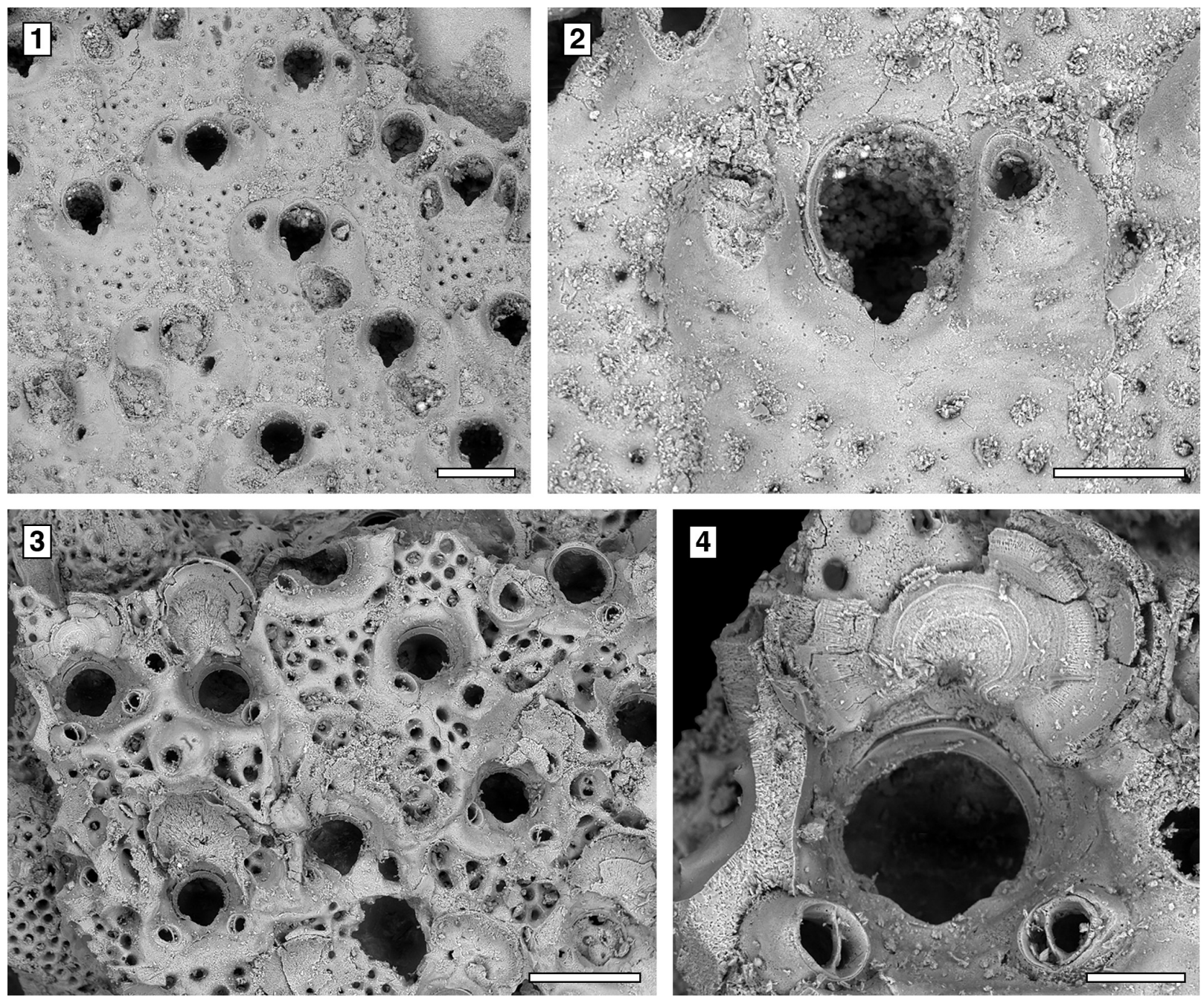

FIGURE 41. Stephanosella biaperta Michelin, 1842 sensu Canu and Bassler (1923). 1-2, USNM 68544. 1, group of autozooids $(200 \mu \mathrm{m})$. 2, close-up of the orifice $(100 \mu \mathrm{m})$. 3-4, USNM 68546. 3, group of zooids, some with incomplete ovicells $(200 \mu \mathrm{m}) .4$, close-up of an orifice, lateral avicularia and incomplete ovicell $(50 \mu \mathrm{m})$.

Remarks. Pourtalesella was introduced by Winston (2005) for species very closely related to Buffonellaria, but with a pseudoporous frontal shield. Four species are currently attributed to Pourtalesella, all recent and all from the western Atlantic. Pourtalesella incrassata (Canu and Bassler, 1928a) from the Gulf of Mexico differs from the Tamiami Formation species in having fewer (about 20 ), larger pseudopores and avicularia with serrated rostra; P. rugosa (Osburn, 1940) from Puerto Rico differs also in having fewer pseudopores, adventitious avicularia directed proximolaterally and calcification that during ontogeny covers the frontal shield with high irregular ridges leaving only a central area through which the pseudopores may be seen. Pourtalesella carvalhoi (Marcus, 1937) from Bahia (Brazil) differs in having a small avicularium embedded within the peristome and ridged endooecium. Finally, P. alipioi (Marcus, 1955) from Espirito Santo (Brazil) is likely to have been incorrectly placed in this genus as it has oral spines and a perforate endooecium. Canu and Bassler's (1923, pl. 16, figures 4-9) Stephanosella biaperta Michelin, 1842 from the Neogene of North America and Jamaica may seem similar in appearance to Pourtalesella chiarae sp. nov. However, after SEM examination, it appears that the specimens figured by Canu and Bassler (1923) (USNM 68544 and USNM 68546) belong to two different species, both differing from Pourtalesella chiarae sp. nov. USNM 68544 (Figure 41.1-2) seems to be an undescribed species of Pourtalesella, which we defer formally naming because it lacks ovicells; it differs from the Tamiami Formation species in having adventitious avicularium placed much more distally and an orifice with a much narrower sinus. USNM 

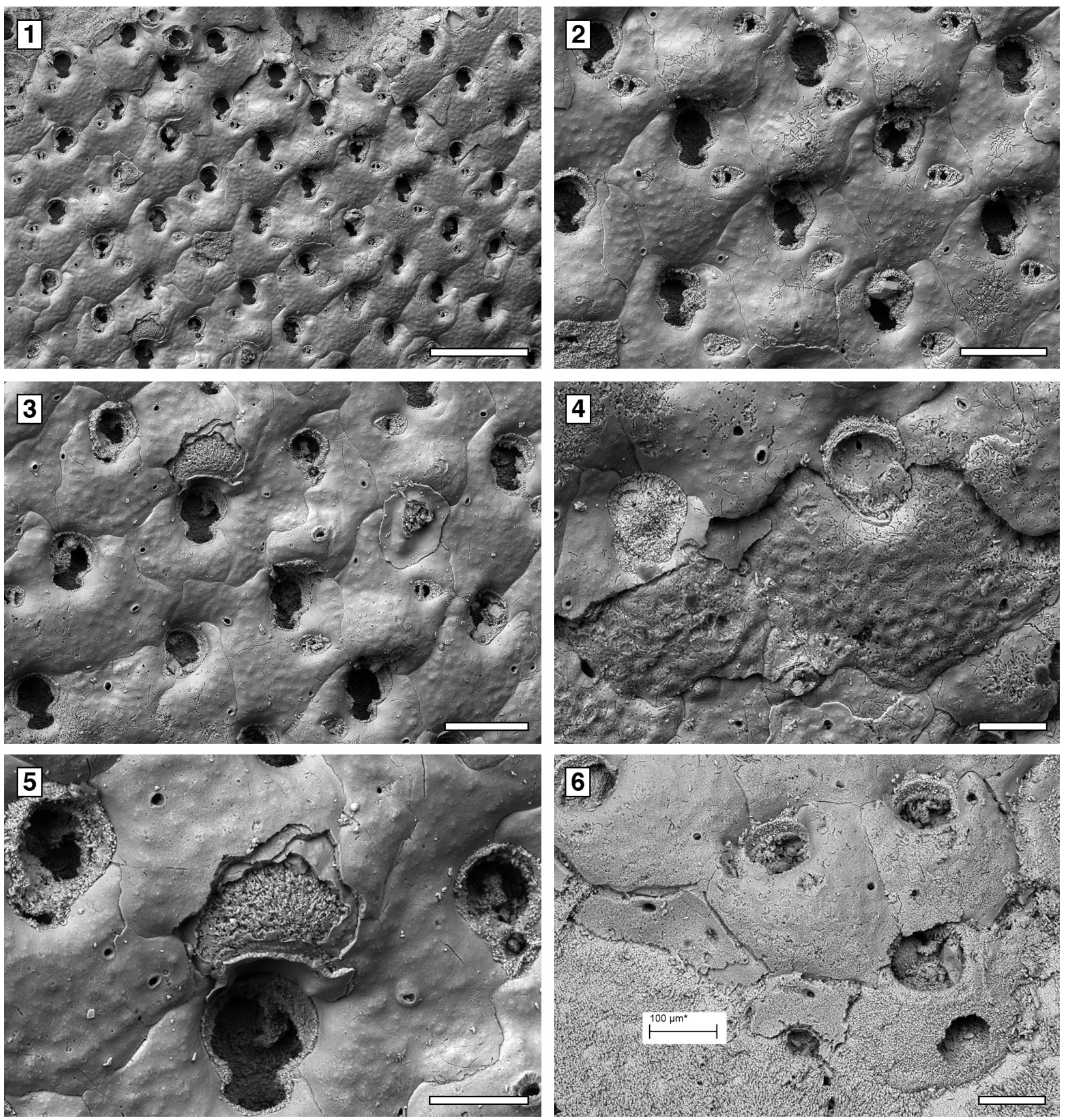

FIGURE 42. Plesiocleidochasma cf. vestitum (Canu and Bassler, 1923), Pliocene, lower Tamiami Formation Units 10/ 11. 1-5, UF 305821 (Shell 14). 1, group of ovicellate and non-ovicellate zooids $(500 \mu \mathrm{m})$. 2, close-up of three ovicellate zooids $(200 \mu \mathrm{m}) .3$, group of zooids with secondary calcification spreading from marginal areolar pores $(200 \mu \mathrm{m})$. $\mathbf{4}$, autozooids with closure plates $(100 \mu \mathrm{m})$. 5, damaged ovicell showing the superposition of calcareous layers (100 $\mu \mathrm{m})$. 6, UF 305822 (Shell 11), tatiform ancestrula and first budded zooids (100 $\mu \mathrm{m})$.

68546 (Figure 41.3-4) is likely to be a specimen of $P$. rugosa because of the characteristic ridges on the frontal shield developed through secondary calcification during ontogeny.

Family Phidoloporidae Gabb and Horn, 1862 Genus Plesiocleidochasma Soule, Soule, and
Chaney, 1991

Plesiocleidochasma cf. vestitum (Canu and

Bassler, 1923)

Figure 42

cf. 1923 Hippoporina (?) vestita Canu and Bassler, p. 130, figures 7-205. 
Figured material. UF 305821 (Shell 14); UF 305822 (Shell 11). Pliocene, lower Tamiami Formation.

Description. Colony encrusting, multiserial, unilaminar (Figure 42.1). Autozooids distinct, with shallow interzooidal furrows, becoming indistinct later in ontogeny as a result of secondary calcification spreading from the marginal areolar pores, quincuncially arranged, hexagonal, almost as long as wide (mean L/W 1.08). Frontal shield slightly convex distally just below the orifice, rarely produced into a rounded, raised umbo, nodular, imperforate apart from one or two, rarely four, very small, circular areolar pores, 10-15 $\mu \mathrm{m}$ in diameter, located at lateral zooidal corners, almost symmetrically placed when paired (Figure 42.2-3). Orifice longer than wide, cleithridiate with two small, rounded condyles separating a deeply arched horseshoe-shaped anter from a shallow, narrower poster; oral spine bases observed only in early astogenetic zooids. Avicularia adventitious, teardrop-shaped, small, usually single but absent in some autozooids, budded from one of the two lateral marginal pores, placed approximately horizontally and directed laterally outwards; rostrum acutely triangular, rounded and crossbar complete. Ovicells globular, imperforate, becoming quickly immersed in the frontal shield of the next distal zooid (Figure 42.2, 5). Closure plates common, smooth with a small, circular opening distally (Figure 42.4). Secondary calcification spreading copiously from the marginal areolar pores obliterating the zooidal boundaries (Figure 42.3-5). Ancestrula tatiform with an uncertain number of spine bases and extensive proximal gymnocystal walls sloping gently outwards, budding one distal and one (possibly two) distolateral zooids (Figure 42.6). First budded zooids smaller than later autozooids, lacking avicularia and with three, small, oral spine bases.

Measurements $(\mu \mathrm{m})$. ZL 353 $\pm 25,311-403(1,20)$; ZW 326 $\pm 37,235-400$ (1, 20); OL 133 $\pm 4,127-142$ (1, 15); OW 110 $\pm 5,100-118(1,15)$; AvL 80 $\pm 6,64-$ 87 (1, 15); AvW 56 $\pm 4,50-61(1,15)$; OvL 157 \pm 10 ,

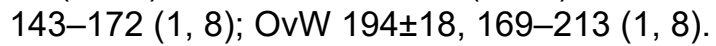

Remarks. Canu and Bassler (1923) tentatively attributed this species to the genus Hippoporina. From the images they provided (pl. 18, figures 79 ), it would now be placed in Plesiocleidochasma. The specific name 'vestitum' derives from the main character attributed by the authors to the species (p. 130) "The zooecia [...] covered by two or three superposed calcareous pellicles". The same character is present in our species, in which copious secondary layers of calcification spread from the marginal areolar pores. In addition, these superimposed 'calcareous pellicles' are clearly visible in the broken ovicell depicted in Figure 42.5. Thus, we refer the Tamiami Formation species to Plesiocleidochasma cf. vestitum. The holotype of $P$. vestitum was described from the Choctawhatchee Marl (now assigned to the upper Pliocene Jackson Bluff Formation) of Florida. Unfortunately, the type specimen lacks avicularia and complete ovicells.

\section{DISCUSSION}

The bryozoan assemblage found encrusting Anomia simplex shells in Units 10/11 of the upper Pliocene lower Tamiami Formation in Florida is described here for the first time. The fauna is relatively low in diversity, comprising 29 species in 26 genera and 22 families, and including a single cyclostome and 28 cheilostomes (nine anascanand 19 ascophoran-grade). Acanthodesia and Microporella are the only two genera represented by more than one species, specifically two and three species, respectively. Two species of Microporella are new to science. In addition to Microporella, the fauna includes new species of Micropora, Spiniflabellum, Trypostega, and Pourtalesella, making a total of six new species. Only two families are represented by more than a single genus, i.e., Calloporidae with four genera and Cribrilinidae with two genera. Eighteen of the bryozoans are established taxa identifiable to the species level, although some only tentatively. Among these, six species are extant and have western Atlantic distributions, while 12 species are known only as fossils, with the earliest record dating back to the early Miocene. Five species can be identified only to genus level owing to deficient preservation and a scarcity of available material.

The bulk of the assemblage is accounted for by five species that are very abundant $(>500$ colonies), while nine species are very rare ( $<10$ colonies) (see Table 1). Most species form extensive, sheet-like colonies consisting of hundreds of zooids and occasionally completely enveloping the shell substrate. Six species have multilayered, flat colonies, and a single species forms multilaminar, mounded colonies.

Echols (1960) identified 26 species of bryozoans (one cyclostome and 25 cheilostomes) from other exposures of the Tamiami Formation. No images are available in his unpublished Masters dissertation, making any comparisons with the fauna described here difficult. Only two of the species mentioned by Echols (1960) - Aplousina gran- 
dis and Cyclocolposa perforata - were also found encrusting the Anomia shells. However, it is likely that the two assemblages share more than just these two species. For instance, Echols (1960) described three species of Microporella, two of which he identified as $M$. ciliata (Pallas) and $M$. marsupiata (Busk), species that, before the advent of the SEM, were recorded worldwide, while the third species, M. pontifica Osburn, might correspond to our M. cf. pontifica (see Remarks).

Outer surfaces of the Anomia shells are encrusted in $96 \%$ of the shells analyzed, while inner surfaces are encrusted in $58 \%$ of the shells analyzed; however, $25 \%$ of the shells have adherent sediment that prevent observation of the entire inner surface. The high proportion of shells encrusted on their inner surfaces is consistent with post-mortem colonization of the shells.

Although the most abundant epibionts, bryozoans are not the only taxonomic group encrusting the Anomia shells, which host lesser numbers of the coral Astrangia, barnacles, foraminifera, and spirorbid polychaetes. A small number of interactions are present between bryozoan colonies and these groups of organisms, while a much larger number of interactions can be observed between the bryozoans, both intra- and interspecific. This taxonomic work establishes the necessary baseline for ranking the different bryozoan species in a competitive hierarchy, which will be the subject of a future palaeoecological study.

\section{ACKNOWLEDGMENTS}

We thank L.J. Cotton (University of Bristol) who helped collecting the specimens; M. SpencerJones (Department of Life Sciences, Natural History Museum, London) for arranging the loan of the type specimens in her care; J. Sanner (Department of Paleobiology, National Museum of Natural History, Smithsonian Institution, Washington, DC, USA) for providing SEM images of Canu and Bassler's material in her care. T. Perkins (Volunteer Program, Natural History Museum London) helped processing the samples. E. Henshaw, Jr. (President) of Schroeder-Manatee Ranch (SMR) Aggregates, Inc. kindly allowed access to the quarry. S. Roberts (Florida Museum of Natural History, University of Florida) provided assistance with Figures 1,2 , and 3.

This research was funded by the Leverhulme Trust, Research Project Grants 'Origin of high tropical diversity: a test using bryozoans', award no. RGP-2015-036 and the Florida Museum of Natural History, Vokes and Florida Fossil Hunters scholarships. This is University of Florida Contribution to Paleobiology 856. Four anonymous reviewers provided very useful comments that greatly improved the originally submitted manuscript.

\section{REFERENCES}

Allmon, W.D., Rosenberg, G., Portell, R.W., and Schindler, K.S. 1993. Diversity of Atlantic coastal plain mollusks since the Pliocene. Science, 260:1626-1629. https://doi.org/10.1126/ science.260.5114.1626

Almeida, A.C.S., Souza, F.B.C., Menegola, C., and Vieira L.M. 2017. Diversity of marine bryozoans inhabiting demosponges in northeastern Brazil. Zootaxa, 4290:281-323. https:// doi.org/10.11646/zootaxa.4290.2.3

Audouin, J.V. 1826. Explication sommaire des planches de polypes de l'Egypte et de la Syrie, publiées par Jules-Cesar Savigny, p. 1-339. In Audouin, J.V. (ed.), Description de l'Egypte, ou recueil des observations et des recherches qui ont été faites en Egypte pendant l'expédition de l'armée française. Histoire naturelle Tome 1, 4 Partie. Imprimerie Impériale, Paris.

Bishop, J.D.D. and Househam, B.C. 1987. Puellina (Bryozoa; Cheilostomata; Cribrilinidae) from British and adjacent waters. Bulletin of the British Museum (Natural History), Zoology Series, 53:1-63.

Brown, D.A. 1948. Six new Recent and Tertiary genera of cheilostomatous Polyzoa from New Zealand. Annals and Magazine of Natural History, 1:108-122.

Bryan, J.R. and Means, G.H. 2014. Geology and paleontology of the Florida panhandle, p. 3-38. In Portell, R.W., Hulbert, R.C. Jr., and Robins, C.M. (eds.), 10th North American Paleontological Convention Field Guide.

Busk, G. 1852. An account of the Polyzoa, and sertularian zoophytes, collected in the Voyage of the Rattlesnake, on the coasts of Australia and the Louisiade Archipelago, p. 343-402. In 
MacGillivray, J. (ed.), Narrative of the Voyage of the H.M.S. Rattlesnake 1. T. \& W. Boone, London.

Busk, G. 1856. Polyzoa collected by Mr M'Andrew on the coast of Norway and Finmark in 1856. Annals and Magazine of Natural History, 18:32-36. https://doi.org/10.1080/ 00222935608697573

Busk, G. 1859. A Monograph of the Fossil Polyzoa of the Crag. Palaeontographical Society, London.

Busk, G. 1884. Report on the Polyzoa collected by H.M.S. Challenger during the years 18731876. Part 1. The Cheilostomata. Report on the Scientific Results of the Voyage of the H.M.S. "Challenger", Zoology, 10:1-216.

Canu, F. 1918. Les ovicelles des Bryozoaires cyclostomes. Étude sur quelques familles nouvelles et anciennes. Bulletin de la Societé Géologique de France, 16:324-335.

Canu, F. and Bassler, R.S. 1917. A synopsis of American early Tertiary Cheilostome Bryozoa. United States National Museum Bulletin, 96:1-87. https://doi.org/10.5479/si.03629236.96.1

Canu, F. and Bassler, R.S. 1919. Fossil Bryozoa from the West Indies. Publications of the Carnegie Institution, 291:75-102.

Canu, F. and Bassler, R.S. 1920. North American early Tertiary Bryozoa. Bulletin of the United States National Museum Bulletin, 106:1-879. https://doi.org/10.5479/si.03629236.106.i

Canu, F. and Bassler, R.S. 1923. North American later Tertiary and Quaternary Bryozoa. United States National Museum Bulletin, 125:1-302. https://doi.org/10.5479/si.03629236.125.i

Canu, F. and Bassler, R.S. 1925. Les Bryozoaires du Maroc et de la Mauritanie. Mémoires de la Société des Sciences Naturelles du Maroc, 10:1-79.

Canu, F. and Bassler, R.S. 1927. Classification of the cheilostomatous Bryozoa. Proceedings of the United States National Museum, 69:1-42. https://doi.org/10.5479/si.00963801.69-2640.1

Canu, F. and Bassler, R.S. 1928a. Fossil and Recent Bryozoa of the Gulf of Mexico region. Proceedings of the United States National Museum, 72:1-199. https://doi.org/10.5479/ si.00963801.72-2710.1

Canu, F. and Bassler, R.S. 1928b. Bryozoaires du Brésil. Bulletin de la Société des Sciences de Seine-et-Oise, 9:58-110.

Cook, P.L. 1985. Bryozoa from Ghana. A preliminary survey. Annales Musée de l'Afrique centrale, Sciences Zoologiques, Tervuren, 238:1-315.

Darrell, J.G. and Taylor, P.D. 1989. Scleractinian symbionts of hermit crabs in the Pliocene of Florida. Memoir of the Association of Australasian Palaeontologists, 8:115-123.

Di Martino, E. and Rosso, A. 2015. Revision of the bryozoan genus Gephyrotes Norman, 1903 (Cheilostomata, Cribrilinidae) with the description of two new taxa. Zootaxa, 3941:261-283. https://doi.org/10.11646/zootaxa.3941.2.7

Di Martino, E. and Taylor, P.D. 2017. Some Miocene cheilostome bryozoan genera of Michel Vigneaux - systematic revision and scanning electron microscopic study. Geodiversitas, 39:783-796. https://doi.org./10.5252/g2017n4a7

Di Martino, E. and Taylor, P.D. 2018. Early Pleistocene and Holocene bryozoans from Indonesia. Zootaxa, 4419:1-70. https://doi.org/10.11646/zootaxa.4419.1.1

Di Martino, E., Taylor P.D., and Portell, R.W. 2017. Bryozoans from the lower Miocene Chipola Formation, Calhoun County, Florida, USA. Bulletin of the Florida Museum of Natural History, 53:97-200.

d' Orbigny, A. 1851. Récherches zoologiques sur la classe des Mollusques Bryozoaires. Annales des Sciences Naturelles, Zoologie \& Biologie Animale, 16:292-339.

d' Orbigny, A. 1852. Récherches zoologiques sur la classe des Mollusques Bryozoaires. Annales des Sciences Naturelles, Zoologie \& Biologie Animale, 17:273-348.

d' Orbigny, A. 1853. Mollusques. In R. de la Sagra (ed.), Histoire Physique, Politique et Naturelle de l'lle de Cuba. Arthus Bertrand, Paris.

Echols, R.J. 1960. The bryozoan fauna of the Tamiami Formation (Upper Miocene) of Florida. MSc dissertation. University of Florida, Gainesville.

Esper, E.J.C. 1791. Forsetzungen der Pflanzenthiere in Abbildungen nach der Natur mit Farben erleuchtet hebst Beschreibungen. Nürnberg.

Gabb, W.M. and Horn, G.H. 1862. The fossil Polyzoa of the Secondary and Tertiary formations of North America. Journal of the Academy of Natural Sciences of Philadelphia, 5:111-179.

Gordon, D.P. 2006. Sfeniella, nom. nov. pro Sphenella Duvergier 1924, and Sfeniellidae a new family of umbonuloid-shielded cheilostomes. Courier Forschungsinstitut Senckenberg, 257:65-71. 
Gray, J.E. 1848. List of the specimens of British animals in the collections of the British Museum. Part 1. Centrionae or radiated animals, p. 91-151. Trustees of the British Museum, London.

Harmer, S.F. 1926. The Polyzoa of the Siboga Expedition. Part 2. Cheilostomata Anasca. Siboga Expedition Reports, 28b:183-501.

Hincks, T. 1877. On British Polyzoa. Part II. Classification. Annals and Magazine of Natural History (Series 4), 20:520-532.

Hincks, T. 1879. On the classification of the British Polyzoa. Annals and Magazine of Natural History, 3:153-164.

Johnston, G. 1838. A History of British Zoophytes. W.H. Lizars, Edinburgh, London \& Dublin.

Jones, D.S., MacFadden, B.J., Webb, S.D., Mueller, P.A., Hodell, D.A., and Cronin, T.M. 1991. Integrated geochronology of a classic Pliocene fossil site in Florida: linking marine and terrestrial biochronologies. The Journal of Geology, 99:637-648.

Jullien, J. 1882. Note sur une nouvelle division des Bryozoaires Cheilostomiens. Bulletin de la Société Zoologique de France, 6:271-285.

Jullien, J. 1883. Dragages du 'Travailleur'. Bryozoaires cheilostomiens. Bulletin de la Société Zoologique de France, 7:497-529.

Jullien, J. 1886. Les Costulidées, nouvelle famille de bryozoaires. Bulletin de la Société Zoologique de France, 11:601-620.

Jullien, J. 1888. Bryozoaires. Mission Scientifique du Cap Horn 1882-1883, Zoologies, 6:1-92.

Knowles, T. 2008. The cheilostome bryozoan Floridina from Plio-Pleistocene deposits of the Coastal Plain of North America. Virginia Museum of Natural History, Special Publication, 15:85-92.

Lamouroux, J.V.F. 1812. Extrait d'un mémoire sur la classification des Polypiers coralligènes non entièrement pierreux. Nouveau Bulletin Scientifique de la Société Philosophique, 3:181-188.

Lamouroux, J.V.F. 1821. Exposition méthodique des genres de l'ordre des polypiers, avec leur description et celles des principales espèces figurées dans 84 planches, les 63 premiers appartenant à l'histoire naturelle des zoophytes d'Ellis et Solander. V. Agasse, Paris.

Levinsen, G.M.R. 1909. Morphological and systematic studies on the cheilostomatous Bryozoa. Nationale Forfatterers Forlag, Copenhagen. https://doi.org/10.5962/bhl.title.5690

Lonsdale, W. 1845. Report on the corals from the Tertiary Formations of North America collected by Mr. Lyell, and described by W. Lonsdale, Esq., F.G.S. 1. Account of ten species of Polyparia obtained from the Miocene Tertiary Formations of North America. Quarterly Journal of the Geological Society, 1:495-509. https://doi.org/10.1144/GSL.JGS.1845.001.01.97

MacGillivray, P.H. 1895. A monograph of the Tertiary Polyzoa of Victoria. Transactions of the Royal Society of Victoria, 4:1-166. https://doi.org/10.5962/bhl.title.6076

Marcus, E. 1937. Bryozoários marinhos Brasileiros, 1. Boletim da Faculdade de Filosofia, Ciências e Letras da Universidade de Sao Paulo, Zoologia, 1:5-224. https://doi.org/ 10.11606/issn.2526-4877.bsffclzoologia.1937.113912

Marcus, E. 1955. Notas sobre briozoos marinhos Brasileiros. Arquivos do Museu Nacional do Rio de Janeiro, 42:273-341.

Michelin, H. 1842. Zoophytes. Revue et Magasin de Zoologie, vol. 2.

Milne Edwards, H. 1838. Mémoire sur les Crisies, les Hornères, et plusieurs autres Polypes vivants ou fossiles dont l'organisation est analogue à celle des Tubulipores. Annales des Sciences Naturelles, Zoologie (série 2), 9:193-238.

Neviani, A. 1896. Appunti bibliografici per servire alla storia degli studi sui Briozoi. Rivista Italiana di Scienze Naturali, Siena, 16:1-7, 25-28, 35-38.

Nikulina, E.A. 2010. Three new genera of Electridae (Bryozoa): Arbopercula, Osburnea, and Arbocuspis. Schriften des Naturwissenschaftlichen Vereins für Scleswig-Holstein, 72:25-28.

Nikulina, E.A. and Taylor, P.D. 2009. Two new species of Electra (Bryozoa, Cheilostomata) from the Miocene of the Aquitaine Basin, France. Geobios, 43:219-224. https://doi.org/10.1016/ j.geobios.2009.09.003

Norman, A. 1903. Notes on the natural history of East Finmark, Polyzoa. Annals and Magazine of Natural History (series 7), 11:567-598. https://doi.org/10.1080/00222930308678818

Osburn, R.C. 1914. The Bryozoa of the Tortugas Islands, Florida. Papers from the Tortugas Laboratory of the Carnegie Institution of Washington, 5:183-222.

Osburn, R.C. 1940. Bryozoa of Porto Rico with a résumé of the West Indian bryozoan fauna. New York Academy of Sciences, Scientific Survey of Porto Rico and the Virgin Islands, 16:321-486. 
Osburn, R.C. 1950. Bryozoa of the Pacific coast of America, part 1, Cheilostomata-Anasca. Report of the Allan Hancock Pacific Expeditions, 14:1-269.

Osburn, R.C. 1952. Bryozoa of the Pacific coast of America, part 2, Cheilostomata-Ascophora. Report of the Allan Hancock Pacific Expeditions, 14:271-611.

Petuch, E.J. 1982. Notes on the molluscan paleoecology of the Pinecrest beds at Sarasota, Florida with the description of Pyruella, a stratigraphically important new genus (Gastropoda: Melongenidae). Proceedings of the Academy of Natural Sciences of Philadelphia, 134:1230.

Ramalho, L.V. and Calliari, L. 2015. Bryozoans from Rio Grande do Sul Continental Shelf, southern Brazil. Zootaxa, 3955:569-587. https://doi.org/10.11646/zootaxa.3955.4.8

Ramalho, L.V., Muricy, G., and Taylor, P.D. 2011. Taxonomic revision of some lepraliomorph cheilostome bryozoans (Bryozoa: Lepraliomorpha) from Rio de Janeiro State, Brazil. Journal of Natural History, 45:13-14, 767-798. https://doi.org/10.1080/00222933.2010.535917

Reuss, A.E. 1848. Die fossilen Polyparien des Wiener Tertiärbeckens. Naturwissenschaftliche Abhandlungen Wien, 2:1-109.

Scolaro, R.J. 1968. Paleoecology of the Bryozoa of the Chipola Formation, Clarksville area, Florida. Ph.D. dissertation. Tulane University, New Orleans.

Silén, L. 1941. Cheilostomata Anasca (Bryozoa) collected by Prof. Dr. Sixten Bock's expedition to Japan and the Bonin Islands 1914. Arkiv för Zoologi, 33A:1-130.

Smitt, F.A. 1873. Floridan Bryozoa, collected by Count L.F. de Pourtales. II. Kongliga Svenska Vetenskaps-Akademiens Handlingar, 11:1-83.

Soule, J.D., Soule, D.F., and Chaney, H.W. 1991. New tropical Pacific and Indian Ocean Cleidochasmatidae (Cheilostomata: Ascophora), p. 465-486. In Bigey, F.P. and d'Hondt, J.-L. (eds.), Bryozoa Living and Fossil. Société des Sciences Naturelles de l'Ouest de la France, Nantes.

Taylor, P.D., Martha, S.O., and Gordon, D.P. 2018. Synopsis of 'onychocellid' cheilostome bryozoan genera. Journal of Natural History, 52:1657-1721. https://doi.org/10.1080/ 00222933.2018.1481235

Taylor, P.D. and Tan, S.-H.A. 2015. Cheilostome Bryozoa from Penang and Langkawi, Malaysia. European Journal of Taxonomy, 149:134. https://doi.org/10.5852/ejt.2015.149

Tilbrook, K.J. 2006. Cheilostomatous Bryozoa from the Solomon Islands. Santa Barbara Museum of Natural History Monographs 4 (Studies in Biodiversity Number 3), 4:1-386.

Ulrich, E.O. and Bassler, R.S. 1904. Miocene. Bryozoa. Maryland Geological Survey, 1904:404429.

Vieira, L., Spencer Jones, M., and Taylor, P.D. 2014. The identity of the invasive fouling bryozoan Watersipora subtorquata (d'Orbigny) and some other congeneric species. Zootaxa, 3857:151-182. https://doi.org/10.11646/zootaxa.3857.2.1

Vigneaux, M. 1949. Révision des Bryozoaires néogènes du Bassin d'Aquitaine et essai de classification. Mémoires de la Société Géologique de France, 28:1-153.

Winston, J.E. 2005. Redescription and revision of Smitt's "Floridan Bryozoa" in the collection of the Museum of Comparative Zoology, Harvard University. Virginia Museum of Natural History Memoir, 7:1-147.

Winston, J.E. 2016. Bryozoa of Floridan Oculina reefs. Zootaxa, 4071:1-81. https://doi.org/ 10.11646/zootaxa.4071.1.1

Winston, J.E. and Vieira, L. 2013. Systematics of interstitial encrusting bryozoans from southeastern Brazil. Zootaxa, 3710:101-146. https://doi.org/10.11646/zootaxa.3710.2.1

Winston, J.E., Vieira, L., and Woollacott, R.M. 2014. Scientific results of the Hassler Expedition. Bryozoa. No. 2. Brazil. Bulletin of the Museum of Comparative Zoology, 161:139-239. https:/ /doi.org/10.3099/MCZ14.1

Zullo, V.A. and Harris, W.B. 1992. Sequence stratigraphy of marine Pliocene and lower Pleistocene deposits in southwestern Florida: preliminary assessment. In Scott, T.M. and Allmon, W.D. (eds.), Plio-Pleistocene Stratigraphy and Paleontology of Southern Florida. Florida Geological Survey, Special Publication, 36:27-40. 